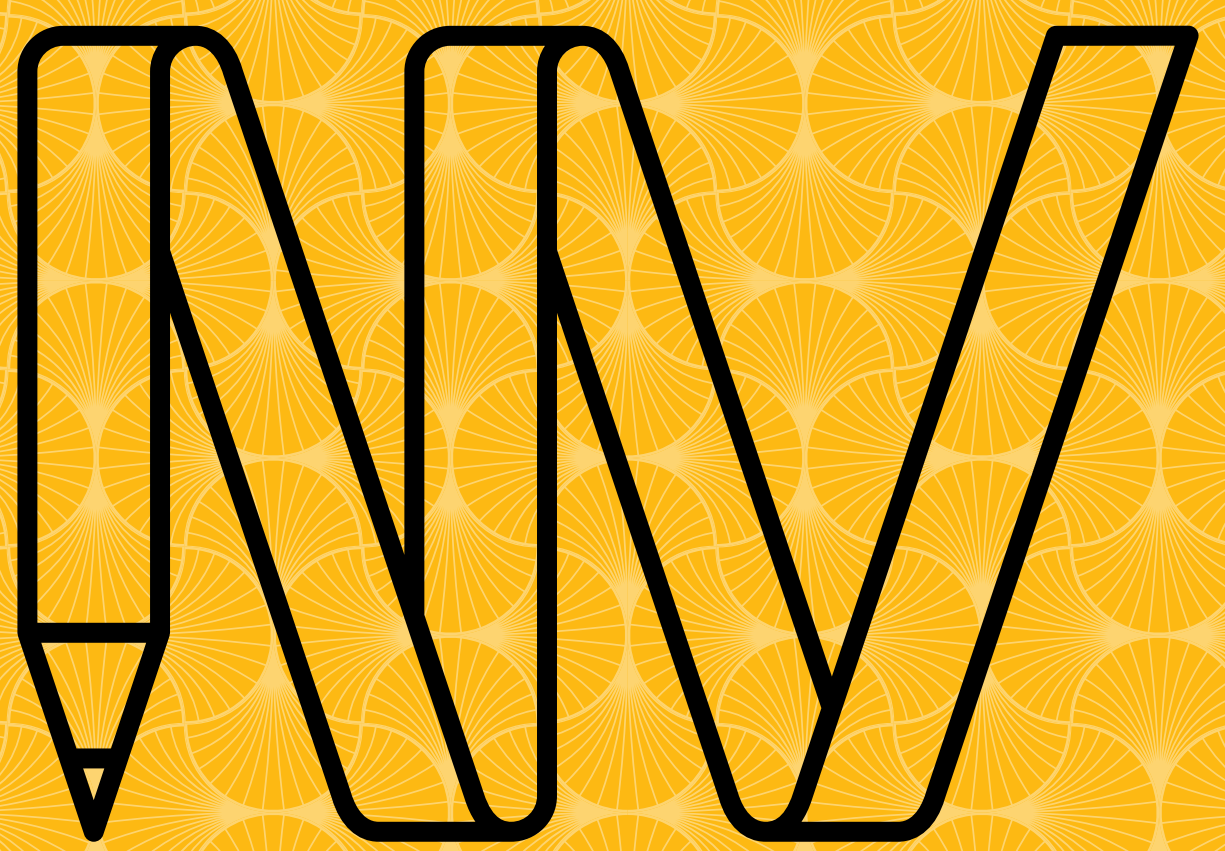

\title{
NEW VOICES
}

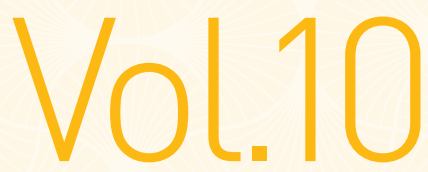

IN JAPANESE STUDIES 


\section{New Voices in Japanese Studies Volume 10}

\section{An interdisciplinary, peer-reviewed journal showcasing the work of emerging scholars from Australia and New Zealand with research interests in Japan.}

GUEST EDITOR, VOLUME 10

Dr Penny Bailey, The University of Queensland

EDITORIAL ADVISORY BOARD (in alphabetical order)

Dr Adam Broinowski, Australian National University

Dr Mio Bryce, Macquarie University

Dr Christine de Matos, The University of Notre Dame Australia

Dr David Envall, Australian National University

Dr Lucy Fraser, The University of Queensland

Dr Olivier Krischer, The University of Sydney

Dr Jun Nakamura, Massey University

Dr Ikuko Nakane, University of Melbourne

Dr Yuji Sone, Macquarie University

Dr Keiko Tamura, Australian National University

Associate Professor Beatrice Trefalt, Monash University

\section{SERIES EDITOR}

Elicia O'Reilly, The Japan Foundation, Sydney

\section{ACTING SERIES EDITOR}

Leah Sourris, The Japan Foundation, Sydney

\section{HEAD OF DEPARTMENT}

Ayusa Koshi, The Japan Foundation, Sydney

All submissions to New Voices in Japanese Studies are peer reviewed by a board of independent academic experts to meet the HERDC requirements for refereed journal status. This and other volumes are available for download via the New Voices in Japanese Studies website. the Directory of Open Access Journals and Ingenta Connect.

www.newvoices.org.au | www.doaj.org | www.ingentaconnect.com

The views expressed in this journal are those of the authors, and do not necessarily coincide with those of the editors, the members of the Editorial Advisory Board or The Japan Foundation, Sydney.

Japanese names are written in first name-surname order, in accordance with English-language convention. The long vowel sound in Japanese is indicated by a macron (e.g., kotsu), unless in common use without (e.g., Tokyo).

\section{PUBLISHED BY}

The Japan Foundation, Sydney

Level 4, Central Park

28 Broadway, Chippendale NSW 2008

www.jpf.org.au

July 2018

New Voices in Japanese Studies, Volume 10 is copyright (c) The Japan Foundation, Sydney and the authors. Copyright of the collection belongs

to The Japan Foundation, Sydney. Copyright of the work belongs to the authors.

All third-party images have been reproduced with permission

where possible, and copyright remains with the original copyright holders.

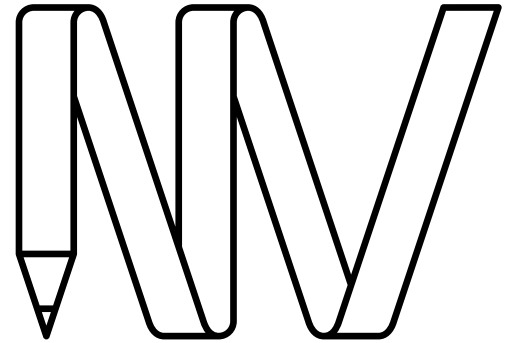

NEW

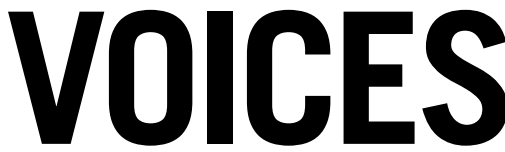

IN JAPANESE STUDIES

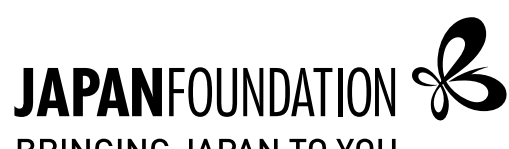

BRINGING JAPAN TO YOU

To link to this volume:

https://doi.org/10.21159/nvjs.10

ISSN 2205-3166

All articles can be downloaded free at newvoices.org.au

(C) The Japan Foundation, Sydney, 2018

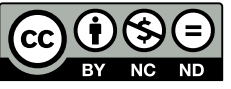

With the exception of images or other material identified as copyright of a third party, this content is licensed under the Creative Commons AttributionNonCommercial-NoDerivatives 4.0 International Licence. All other rights reserved. Permission requests for usages outside those governed by this licence should be directed to the Series Editor at newvoices@ijpf.org.au

We request attribution as follows: (C) The Japan Foundation, Sydney / [author name], [year of publication]. 


\section{Foreword}

As the height of winter approaches again, it is my pleasure to introduce Volume 10 of New Voices in Japanese Studies. It is no small feat for NVJS to be releasing its tenth edition. The journal is a modestly staffed and resourced publication which owes its continuation to the involvement of established local Japanese Studies academics who support the journal's mission of mentoring up-andcoming scholars. These academics have played a crucial role in the journal over its life to date, by encouraging postgraduate students to submit and refine their papers, by lending their expertise to peer review and-in the case of ten particularly dedicated individuals - by taking on the central role of guest editor.

Importantly, NVJS also owes this milestone to the continuing enthusiasm, passion and discipline of local postgraduate scholars who choose to focus their research on Japan and then share that work within this journal. This anniversary volume features a small but robust selection of papers on a diverse range of themes by a mostly Honours-level cohort of authors. It is indeed encouraging to see such incisive and rigorous Japan-related research emerging at postgraduate level, and predominantly Honours level at that. With young researchers of this calibre on the horizon, it is with excitement that I look to the future of Japanese Studies locally.

This volume would not have been possible without the dedicated guidance and assistance of Guest Editor Dr Penny Bailey from The University of Queensland. Despite a demanding teaching schedule among other important commitments, Dr Bailey gave incredibly generously of her time and expertise over multiple readings of these and other submissions to ensure the integrity of this volume. The role of Guest Editor is at times demanding; I am grateful to Dr Bailey for not just meeting but exceeding these demands-always with consummate grace, and always with a keen eye for balancing the sometimes conflicting needs of academic publishing. On behalf of the NVJS team, I thank you for helping this volume to become the very best it could possibly be.

I would also like to extend my thanks to this year's Editorial Board, who also gave generously of their time and expertise to help the authors develop their submissions. Their feedback has been incredibly valuable in shaping the papers in this volume-as has the feedback of the authors' academic supervisors, who so kindly recommended their students submit to NVJS. As well, I wish to acknowledge the contributions of last year's Guest Editor, Dr Olivier Krischer, and Acting Series Editor Leah Sourris to this volume, as some of the papers published here were initially submitted in a previous call for papers and have benefited from their feedback. 
Turning now to the current team, I wish to thank the NVJS Series Editor, Elicia O'Reilly, for her efforts not only in bringing this volume to fruition, but also in establishing two new partnerships this year: one with the EBSCOhost research database, and another with Ithenticate. The EBSCOhost partnership comes in addition to NVJS's existing indexation in the Directory of Open Access Journals (DOAJ) and Ingenta databases, and will surely see the journal's reach expand. Meanwhile, the Ithenticate partnership adds an increased layer of certainty to the publication process, further enhancing the journal's credibility as a platform for original local research. My thanks also go to Supervising Manager Ayusa Koshi for supporting this project.

Last but certainly not least, I wish to thank the authors who submitted their work for this volume of NVJS. As always, there are some authors whose work was not selected for this volume, but I hope that they found the editorial feedback they received to be valuable, and I join the editors in encouraging and welcoming these authors to revise and resubmit. To those authors whose research is published here, I congratulate you on your hard work, and I am glad to know that the result is a rigorous academic article of which you can be proud. I wish you all the very best for your future, and look forward to seeing further contributions from you in the scholarly sphere over the years to come.

\section{Yoshihiro Wada}

\section{Director}

The Japan Foundation, Sydney

July 2018 


\section{Contents}

Foreword

v Introduction

Dr Penny Bailey

1 The Experiences of Nikkei-Australian Soldiers During World War II Shannon Whiley

29 Governor Takeshi Onaga and the US Bases in Okinawa: The Role of Okinawan Identity in Local Politics

Monica Flint

“Watashi-tachi wa ningen da!": A Corpus-Assisted Analysis of a Non-Human Character in the Anime Series 'From the New World' Kelvin K. H. Lee

76 Straddling the Line: How Female Authors are Pushing the Boundaries of Gender Representation in Japanese Shōnen Manga Daniel Flis 
This volume of New Voices in Japanese Studies marks the tenth iteration of the journal since it was first published in December 2006 under the direction of Series Editors Wakao Koike and David Boyd of The Japan Foundation, Sydney; Guest Editor Dr Yuji Sone; and an Editorial Advisory Board of esteemed scholars in Japanese Studies across Australia and New Zealand. Each subsequent volume of the journal has been realised thanks to the efforts of many devoted individuals whose vision to support experience in the publishing arena among emerging Japanese Studies scholars has both contributed to the invigoration of new scholarship on Japan in the region and worked to encourage many contributors to further their postgraduate studies and establish careers in the field.

The four papers in this volume are broadly linked by themes associated with identity construction and perception. Laying the groundwork for meaningful and original contributions, Shannon Whiley's research draws substantially from Australian archival materials, while the papers by Monica Flint, Kelvin Lee and Daniel Flis share rigorous engagement with Japanese-language primary source materials. Situated in fields as diverse as military studies, political studies, linguistics and comparative literature studies, their topics are both historical and contemporary, ranging from examinations of national belonging, racial marginalisation and wartime experience to investigations into the construction of anime character traits and the production of gendered language and visuals in Japanese popular culture texts. This diversity in content not only highlights the dynamism that characterises local scholarship on Japan, but also underscores the value in producing a specialist journal dedicated to introducing the rich array of postgraduate and early career scholarship emerging in Australia and New Zealand to a broader audience.

Shannon Whiley delves into Australian military history in order to examine the experiences of three Japanese-Australians-Mario Takasuka, Joseph Suzuki and Winston Ide-who volunteered to serve in World War II. In challenging familiar tropes about the demographic of soldiers who served for Australia, Whiley's paper aligns with a growing scholarly trend which recognises and celebrates the frequently overlooked but vital roles that marginalised groups such as Nikkei-Australians, as well as ChineseAustralians and Indigenous Australians, played in defending Australia's wartime interests. Based on documents sourced largely from the National Archives of Australia, the paper highlights the men's experience of lingering attitudes associated with the White Australia Policy, the ambiguity of enlistment guidelines, the threat of internment and the camaraderie they

\author{
.
}


shared with their fellow soldiers. The sociopolitical significance of the paper is brought sharply into focus with an insightful analysis on the dissonances that emerged in the ways that Takasuka, Suzuki and Ide were viewed and treated by the Australian government and their communities, and how they perceived themselves.

Monica Flint also addresses issues of identity and belonging to investigate the ways in which Okinawan Governor Takeshi Onaga has shaped the ongoing debate about the presence of US military bases in the prefecture. As Flint argues, since assuming office in December 2014, Onaga has marshalled attention towards heightened regional tensions between Japan and its neighbours and the relevance of the US-Japan Security Alliance to advance essentialist notions of Okinawan cultural identity, ethnicity and history. The paper demonstrates how Onaga has been able to garner support for his electoral mandate by carving out a point of difference with his predecessors through his focus on local identity over political ideology and his widespread use of social media platforms Twitter and YouTube. By analysing Onaga's online presence, Flint sheds light on the ways he has used these new forms of communication as tools to problematise Okinawa's long-standing and entrenched political issues.

Kelvin Lee adopts an innovative mixed-method approach in his paper to explore how telecinematic texts transfer and recontextualise real-world language use in order to convey character traits such as social standing, thoughts and beliefs, and to index shifts in presentational personae. Taking the 2012-13 science-fiction anime series From the New World (Shinsekai Yori) as a case study, Lee investigates the discursive construction of the nonhuman protagonist, Squealer, through an integration of corpus linguistic analysis and scene-based analysis that draws from sociolinguistic theory. The three corpora selected by Lee are comprised of dialogue from the series, and reveal how Squealer's identity is constructed using shifts in social and tonal registers and various other linguistic devices. During the research process, Lee discovered a number of limitations with the software currently available to analyse Japanese-language corpora. He also shares these insights in the hope that they may aid in the development of future versions.

Daniel Flis examines two shōnen (boys') manga texts to investigate how visual and textual representations of gender can play out on the page in vastly different ways, even within the same genre. Specifically, the paper highlights how the two female authors of Noragami (2010-), known together as Adachitoka, have challenged the conventional gendered framework of shōnen texts. In resisting the stereotypes and power dynamics that typically characterise the heteronormative narratives of the genre, Noragami subverts such expectations as female characters occupying supporting roles and conforming to traditional ryōsai kenbo ('good wife, wise mother') behaviours. Through an insightful comparative analysis with the male-authored Akame ga Kill! (2010-2016) — which shares a number of other traits with NoragamiFlis demonstrates how Adachitoka have successfully presented new forms of gender performance that depart significantly from the shonen framework but also manage to negotiate a degree of fidelity to the genre. 
As with previous volumes of New Voices in Japanese Studies, each paper submitted for consideration in Volume 10 underwent a rigorous peer-review process which was reliant on the goodwill of many individuals. I would like to express my deep gratitude to the many scholars who generously invested time in providing thoughtful and constructive feedback both to the authors of the papers in this volume, and to those whose submissions required more time and reflection than the demands of the publishing schedule could accommodate. To the contributors, I commend you on your diligence and perseverance in what may have seemed like endless rounds of feedback and corrections: you should be very proud of your papers. To those whose submissions did not make it to publication, I encourage you to continue working on your research for consideration in future volumes of the journal.

Finally, I am humbled to have been offered the role of Guest Editor for this volume. I would like to extend my sincere thanks to The Japan Foundation, Sydney, and in particular to Director Yoshihiro Wada for this invaluable opportunity. I am also indebted to Series Editor Elicia O'Reilly, whose editorial, organisational and diplomatic skills are superlative. Elicia's good humour and tenacity kept the production process moving forward, at times under difficult conditions. Heartfelt thanks also to Acting Series Editor Leah Sourris, who expertly and patiently guided Volume 10 through the initial stages while Elicia was on leave. The production of this volume was interspersed with a number of personal milestones for the editorial team-including a baby's first steps (Elicia), the launch of a new career (Leah) and a wedding (Penny)-making it a particularly memorable project for each of us. We hope you will join us in celebrating the achievement of the journal's first ten volumes, and we look forward to your ongoing support as New Voices in Japanese Studies continues in its endeavour to provide a platform for new generations of scholars in Japanese Studies across Australia, New Zealand and beyond.

\section{Dr Penny Bailey}

The University of Queensland 


\section{The Experiences of Nikkei- Australian Soldiers During World War II}
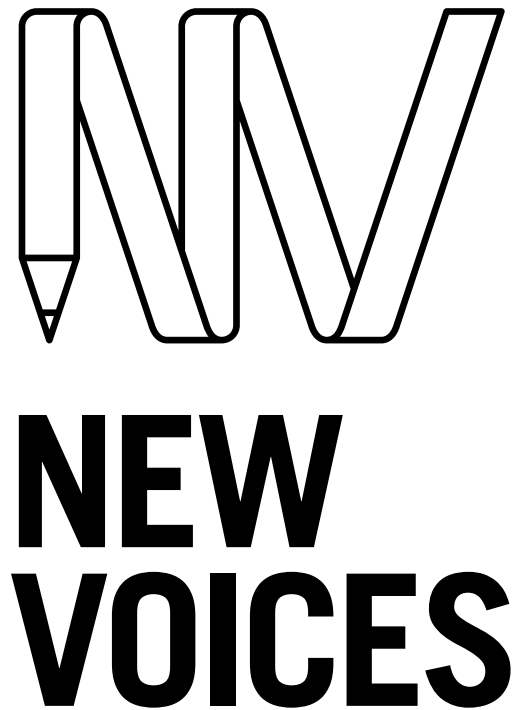

\section{SHANNON WHILEY}

The University of Queensland

\section{ABSTRACT}

This paper is a biographical case study that explores the distinct experiences of three Australian-born Japanese (hereafter, Nikkei-Australians) who volunteered for Australian military service during World War II: Mario Takasuka, Joseph Suzuki and Winston Ide. It examines the social and political context in which these soldiers lived, concluding that they faced a disconnect between the way they were viewed by the government, their local communities and themselves. Notions of identity and nationalism are also explored in the context of World War II and the White Australia Policy, and are compared with the experiences of non-European soldiers in Australia and Nikkei soldiers abroad. The paper also highlights the ambiguous position of Nikkei-Australian soldiers with respect to military enlistment. At the time, legislation allowed for Nikkei-Australians to be variously classified as loyal citizens capable of enlistment, as not sufficiently 'Australian' for duty, or as enemy aliens, depending upon how it was applied in each case. Because there was no uniform approach within the government for applying these laws, the experiences of Nikkei-Australians vastly differed, as illustrated by the stories of the individuals profiled in this study. These stories are important as they add to the growing body of knowledge around non-white Australians who served in World War II, and remind us of how the pro-white, anti-Japanese atmosphere within Australia at the time affected those within the community who did not fit the mould of the White Australian ideal.

\section{KEYWORDS}

Australia; diaspora; history; Japanese Australian; Japaneseness; law; Nikkei; politics; Second Australian Imperial Force; social and cultural identity; soldiers; state; stereotypes; White Australia Policy; World War II

\section{JAPANFOUNDATION 8} BRINGING JAPAN TO YOU

To link to this article: https://doi.org/10.21159/nvjs.10.01

\section{ISSN 2205-3166}

New Voices in Japanese Studies is an interdisciplinary, peer-reviewed journal showcasing the work of emerging scholars from Australia and New Zealand with research interests in Japan.

All articles can be downloaded free at newvoices.org.au

(c) The Japan Foundation, Sydney and Shannon Whiley, 2018

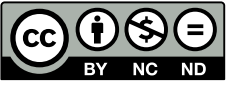

This work is licensed under a Creative Commons Attribution-NonCommercialNoDerivatives 4.0 International License. 


\section{INTRODUCTION}

This paper explores the experiences of a small number of Australians of Japanese descent who served in the Australian military during World War II. It examines their stories in the context of an anti-Asian and Japan-fearing Australia in the early to mid-twentieth century. The wartime experiences of Japanese migrants and their Australian-born descendants (hereafter referred to as Nikkei-Australians) were influenced greatly by the Immigration Restriction Act 1901 and other pieces of legislation that made up the White Australia Policy. ${ }^{1}$ Nikkei-Australians faced great hardships as a result of these policies, which contributed to anti-Japanese sentiment and culminated in the internment of many from 1941. It was in this context that the three NikkeiAustralians profiled in this study volunteered for military service in the Second Australian Imperial Force (AIF). ${ }^{2}$

Research into the histories and experiences of Nikkei-Australians is a developing area with great potential for revealing important stories from non-white Australian perspectives. The experiences of Nikkei-Australians during World War II can be shown to have differed greatly from those of white Australians. Within this context, this article focuses specifically on the experiences of Nikkei who served in the military. Officially, Nikkei-Australians were prohibited from military service, although several were still able to enlist (Nagata 1996, 105). As a result, those who did enlist found themselves in an ambiguous position, fighting for a country that interned their families and classified them as enemy aliens. While scholars have investigated the stories of Nikkei-Australians as a broader population, the stories of Nikkei-Australian soldiers have yet to be explored or examined through the specific lens of their shared military experiences. This is the gap that my paper seeks to address.

Using archival case studies of three Nikkei-Australian soldiers who served in World War II, I will examine how individual variations in the nature of their Japanese heritage influenced their treatment during the war, from 1939 to 1945 . The paper will also delve into questions surrounding the identity of these soldiers, focusing on the tensions between three different images of Nikkei-Australians: 1) how they were seen bureaucratically and legislatively; 2) how they were seen by their local communities and peers; and 3) how they saw themselves. It will show that despite being classified as enemy aliens by the state, Nikkei-Australians were generally accepted by their peers and did not conform to the stereotypes of Japanese people that prevailed within the government and the greater community. As documentation and research relating to Nikkei-Australian soldiers is notably scarce, the paper will also draw from a range of secondary sources on the wartime experiences of non-Australian Nikkei soldiers and Australian soldiers from non-Nikkei racial minorities. These sources focus on the more-widely researched North-American Nikkei soldiers, as well as Chinese-Australian soldiers and

1 Several Japanese terms will be used throughout this paper. 'Nikkei' (日系), meaning 'of Japanese descent', refers to the Japanese diaspora. 'Issei' (一世) and 'Nisei' (二世) refer to the first generation (born in Japan) and second generation (born outside Japan to Issei parents) of the Japanese diaspora respectively. 'NikkeiAustralian' is a modern term referring to cultural heritage as opposed to nationality.

The White Australia Policy was made up of the Immigration Restriction Act 1901, the Naturalisation Act 1903, the Alien Registration Act 1920 and several smaller pieces of legislation.

2 The Second Australian Imperial Force is the name given to the main force of the Australian military that served in World War II. 
Indigenous Australian soldiers. Utilising these stories offers a way of bridging gaps in knowledge regarding the Nikkei-Australian community.

The study collates important examples of non-white Australian experiences during the era of the White Australia Policy. Research of this nature is vital to ensuring commemoration for Nikkei-Australian and other non-white Australian soldiers, given the complexities of their involvement in the war due to their heritage and the political climate of the time. As Australian war historian Jeannine Baker has stated regarding the commemoration of nonwhite Australian soldiers, a universally white Australia "was never true and it's important to recognise that" (Baker et al. 2017). This paper contributes to the growing body of literature commemorating those non-European Australians who served in the military under the White Australia Policy.

\section{METHODOLOGY}

In this paper I utilise archival documents found mainly in the National Archives of Australia (NAA) to examine how race, and mainstream attitudes towards race, shaped the treatment of Nikkei-Australians who served in the Second Australian Imperial Force (AIF) during World War II. The study builds on the research of Nikkei-Australian diaspora scholars such as Yuriko Nagata, Pam Oliver and D. C. S. Sissons. Their identification of several individuals who were members of the Japanese diaspora and also served in the Australian military during World War II has been invaluable to this study. There is no official record of Nikkei-Australian soldiers who served in World War II because Nikkei-Australians were prohibited from enlisting. NikkeiAustralians who did serve in the military were only able to register when enlistment centres were unaware of the enlistee's heritage or regulations regarding race, and therefore information on race was never recorded at the time of enlistment. ${ }^{3}$ Race was generally only noted on attestation papers if it was the reason for discharge (Australian War Memorial [AWM] n.d.[a]). The list of cases collected here therefore represents only a small cross-section of the most diverse and well-documented experiences.

The study focuses on three Nikkei-Australian soldiers and their families, and builds on existing research by analysing the soldiers' respective military experiences with reference to archival information I have located. These soldiers are Mario Takasuka [1910-1999], Joseph Suzuki [b. 1922] and Winston Ide [1914-1944]. ${ }^{4}$ These men are notable because their varying backgrounds and experiences, when examined together, highlight the different social and legal attitudes toward Nikkei-Australians during World War II. They are also distinguished by the relative availability of their historical records. A total of 17 Nikkei soldiers who served in the Australian military have been identified in prior research; however, a comprehensive review of each of these individuals is outside the scope of this study. Known Nikkei-Australian soldiers who served World War II are instead listed in a table in the Appendix. 


\section{HISTORICAL CONTEXT: EARLY TO MID-TWENTIETH CENTURY AUSTRALIA}

Australian policy towards Japan in the early to mid-twentieth century was influenced by a combination of racial attitudes and a perceived exposed position as a European colony in Asia (Anderson 2006, 148). While the severity of Japan's threat to Australian sovereignty and the specifically anti-Japanese sentiment of the time has sometimes been overstated, it is true that politicians and the media did have reservations about Japan long before Japan entered World War II and became an official enemy of Australia (Sissons 1956, 2). Japan's victories in its various wars with China [1895] and Russia [1905] had shown its potential as a strong maritime power, and Japan used this to push for parity with the Western powers-something that the Australian government was staunchly against (Stead 1904, 84-85). Moreover, the notion that Japanese workers could migrate in large numbers and undercut European workers had caused concern within the government and the Australian labour union movement since the gold rush of the 1850s (Haid 2011, 39-40). These fears of a rising Japan directly contributed to the introduction of policies such as the Immigration Restriction Act in 1901 and the establishment of Japanese language classes at the military college of Duntroon in 1917, despite Japan being a nominal ally at the time (Stead 1904; Meaney 2009, 156). During World War II the fear of a Japanese invasion did not seem unfounded, especially between 1942 and 1943, with skirmishes in and around Australian territories during that period referred to by then Prime Minister John Curtin as the "Battle for Australia" (NAA 2017). ${ }^{5}$ Although evidence later emerged that Japan had no real plans for a full-scale invasion of Australia, the atmosphere at the time was increasingly anti-Japanese (Bullard 2006, 21-22). As will be shown below, these policies and fears directly influenced Nikkei-Australian experiences.

\section{IMMIGRATION, NATURALISATION AND CITIZENSHIP POLICIES BETWEEN 1901 AND 1945}

The immigration policies of early twentieth-century Australia were known for favouring white British immigrants. Consequently, the Japanese community in Australia was small and faced discrimination on several fronts (Oliver 2002, 277). The acts that combined to form the White Australia Policy (see footnote 2) were the most significant pieces of legislation affecting the Japanese community in Australia between 1901 and 1945. The Immigration Restriction Act 1901 explicitly excluded Asians and other non-Europeans from entry into Australia. Anti-Chinese sentiment had been building since the gold rush of the 1850s and played an important role in limiting Asian immigration; the smaller Japanese community was oftentimes conflated with the Chinese or simply labelled as 'Asian' (Haid 2011, 43). Nikkei-Australian Hannah Suzuki [b. 1920] stated that during the war she was often mistaken in the community for being Chinese (Nagata 1996, 105). In this way, many of the difficulties faced by Nikkei-Australians were not unique to the Japanese community.

5 One important battle early on in the conflict between Australia and Japan was the Fall of Singapore. This battle was fought between British Allied Forces and Japan at the British Naval Base in Singapore in February 1942. After a decisive victory by the Japanese, 130,000 people were taken as prisoners of war. Japanese war planes bombed Darwin four days after the British surrendered at Singapore. These events were notable as major victories by Japan against Australian troops, and were important as they were seen as a progression towards an invasion of Australia by Japan (Rowland 2017). 
Although anti-immigration legislation does not name the Nikkei-Australian community, several researchers have asserted that it was targeted specifically. Alfred Stead (1904), a researcher in Japanese studies who vehemently opposed the Immigration Restriction Act, argued at the time that the act was primarily introduced to prevent an influx of Japanese migrants (95). Haid (2011) reasons that while the government made little effort to conceal its contempt for Japanese immigrants, an ambiguous restriction method was chosen for diplomatic reasons (51-52). These assertions are supported by statements made by those in power at the time, including Attorney-General Alfred Deakin, who stated: "I contend that the Japanese require to be absolutely excluded [from immigrating to Australia] because of their high abilities [...]. [They] are the most dangerous because they most nearly approach us, and would therefore be our most formidable competitors" (cited in Stead 1904, 95). In practice, this sentiment led to increasingly discriminatory treatment of Nikkei-Australians compared with their Chinese and other Asian-Australian counterparts, and importantly influenced the decision to intern Nikkei-Australians as enemy aliens from 1941 to 1947 (Nagata 2008, 112). As a result of these policies, the Nikkei-Australian community at the start of World War II consisted of those who had arrived before 1901, a small number of people who were able to obtain an exemption and had arrived later, and their descendants. In 1941, this population was estimated at 1,139-around 821 of whom were deported after the war (Haid 2011, 3, 8). ${ }^{6}$

This discriminatory treatment is most clearly reflected in the citizenship rights of Japanese immigrants and their Australian-born descendants, which influenced government and military policy towards Nikkei during World War II. Prior to 1901, it had been possible for Japanese nationals to become naturalised Australian [British] citizens; however, the enactment of the White Australia Policy through the Immigration Restriction Act 1901 effectively annulled this right until 1958, when the act was repealed (Oliver 2008, 125-28, 134). ${ }^{7}$ During the period that the White Australia Policy was in effect, access to citizenship rights became complex for Nikkei and other racial minorities, and factors such as race, country of birth and paternal nationality were used to determine eligibility for citizenship (Beaumont et al. 2008, 5).

The Naturalisation Act 1903 also had a significant impact on citizenship rights. The act stated that only Australian residents who were not "aboriginal native[s] of Asia, Africa or the Islands of the Pacific" were eligible to apply for a certificate of naturalisation. In 1923, one individual, Jiro Muramats, challenged this in the High Court of Australia as he was not an indigenous Japanese (Ainu); however, the court eventually ruled that the word "native" referred to the native race in Japan "from a European perspective" (Haid 2011, 69). ${ }^{8}$ According to Oliver, the wording of this legislation was intentionally left vague and undefined for those who wished to prevent non-whites from claiming citizenship (Oliver 2008, 135). 
Conflicting legislation similarly complicated the citizenship status of Australian-born second-generation Nikkei, known as 'Nisei'. Section 6 of the Commonwealth Nationality Act 1920-30 automatically conferred citizenship on anyone born in Australia, meaning that Nisei should have been considered natural-born Australian [British] citizens under this law. However, according to the Aliens Registration Act 1920, the wife and children of an alien (meaning 'non-citizen' in theory, but in practice meaning 'non-European') could also be classified as aliens, meaning that second-generation immigrants such as Nisei were not necessarily guaranteed citizenship (Nagata 1996, 56-59). These unclear legal definitions forced Nikkei-Australians to exist in a state of ambiguity, especially in wartime. Without the Aliens Registration Act, Nisei would have been classified as Australians rather than enemy aliens.

Underpinning these laws were the prevailing racial theories of the time. The two most significant were those of Charles Pearson, who developed a racial hierarchy theory that influenced Australia's immigration policy, and W. H. Barnwell, whose report on Japanese characteristics and theory of Japanese espionage was used to mark Nikkei-Australians as potential spies as early as the 1920s (Oliver 2002, 274-75; Oliver 2008, 139). Pearson, a Britishborn historian and politician based in Australia, argued that "black and yellow races" (in particular, the Chinese), would grow in population and influence to eventually "supersede" Europeans (Pearson 1893, 32). These theories influenced future Australian Prime Ministers Edmund Barton and Alfred Deakin, the former quoting Pearson's research when campaigning for the Immigration Restriction Act in 1901 (Haid 2011, 48; Pearson 1893, 29). Barnwell's theory, which built on a combination of Pearson's work and information from Australia's security forces, outlined what he deemed to be intrinsic characteristics of the Japanese: secretiveness; untrustworthiness; belonging to the "emperor cult"; and having expertise in espionage tactics (Oliver 2002, 275). Exceptions could be made in cases where an individual did not speak Japanese, was born in Australia, or had a white parent (Oliver 2002, 274-75). However, many officials at the time held firmly to the belief that Nikkei-Australians could never become Australian in their outlook, and that any attempt to do so should be treated with suspicion (Oliver 2002, 287). Barnwell's espionage theory eventually contributed to justifying the internment camps set up in Australia from 1941 to 1947 (Oliver 2002, 274-75). ${ }^{9}$

\section{INTERNMENT POLICY}

After the outbreak of World War II, immigrants from enemy nations and their Australian-born children living in Australia were classified as enemy aliens and interned in camps to minimise their perceived threat to the public and to national security (Beaumont et al. 2008, 67). Those interned included

result of Western Australia retracting his right to vote (Sissons 1986). In 1923, his name was reinstated on the electoral roll. However, his petition to regain citizenship was unsuccessful, which led him to take his case to the High Court. Muramats was interned as a Japanese during World War II and died in internment (Haid 2011, 69). Note that Japanese names reproduced in this paper follow spellings used in official Australian records where possible, or otherwise follow the dominant spellings used in extant literature on Nikkei-Australians. 
German, Italian and Japanese civilians, and in some cases their descendants (Haid 2011, 25). However, while European-Australians were only selectively interned based on alleged security risk and connection to fascist ideologies, it was decreed that all Japanese persons over 16 years of age should be taken into custody (Rando 2005, 27-28; Hayman 1980, 31)..$^{10}$ The legal definition of who was Japanese was unclear, so in practice the internment included Australianborn citizens with Japanese heritage, young children and even Australian spouses of Japanese (Nagata 1996, 51-56). ${ }^{11}$ As Asians, Nikkei-Australians were more easily visually identifiable than those with European heritage, and were thought to pose a greater threat to Australia than non-Asian enemy nationals (Nagata 2008, 112). According to Nagata, the Australian government took the approach of a comprehensive Nikkei internment for four reasons:

...because authorities thought that there were no Japanese associations that might easily indicate the extent of an individual's attachment to his homeland; that the Japanese were not absorbed into Australian society; that they were fanatical and devoted to their homeland and therefore capable of sabotage; and that Japanese men, if left free, would be the target of anti-Japanese public demonstrations.

(Nagata 2008, 112)

In short, anti-Japanese propaganda and the racial policies of the time heavily influenced the decision to intern Nikkei-Australians indiscriminately. Of the three Nikkei-Australian soldiers profiled in this study, one (Joseph Suzuki) was interned, and all had family members who were interned. This internment policy had lasting effects on the Nikkei community in Australia. After the war, the government used this same policy framework as a justification for deporting the majority of Nikkei-Australians, with the exception of those who were Australian-born or those who had Australian-born family members (Nagata 1996, 193). This is further evidence not only of anti-Japanese sentiment within the Australian government at the time, but also of how the government did not consider Nikkei-Australians to be 'Australian'. Although some Nikkei returned to Australia in the 1950s, the post-war Nikkei-Australian community has very few ties to the pre-war community (Nagata 1996).

\section{MILITARY POLICY}

Even prior to World War II, Nikkei-Australians were prohibited from enlisting in the military on racial grounds. Australian Military Regulation No. 177 of the Defence Act 1909 specified that "those who are not substantially of European origin or descent" were to be excluded from service, determined at the discretion of an appointed medical professional (Nagata 1996, 105). As a result, Nikkei-Australians who did serve in the military while this act was in force were only able to enlist by hiding their ancestry from enlistment staff. In cases where the heritage of these individuals was discovered after enlistment, some were able to retain their positions due to intervention and advocacy by their superiors and peers, as will be discussed below (Oliver 2002, 285-88). 
Bureaucratic distrust of Nikkei-Australians meant that they were not considered for military armed service roles, or even translation and interpretation roles-although there were Nikkei-Australians with knowledge of both English and Japanese who may have been suitable for and useful in such positions (Oliver and NAA 2004, 20,126). This was due to the pervasive notion at the time that Nikkei in Australia were spies, and were loyal only to the Japanese emperor (Saunders 1994, 331; Oliver 2002, 275). Instead, World War II Allied Forces employed North-American Nisei and Japanese-speaking Australians of European origin as translators during World War II (Queensland Government 2014). The Allied Translator and Interpreter Service (ATIS, also known as the Allied Translator and Interpreter Section) was a joint Australian/American World War II intelligence agency responsible for translation and intelligence gathering, including interviewing Japanese prisoners of war (POWs) sent to Australia. It is unclear why Nikkei-Americans were considered when local Nikkei-Australians were not, although it is possible that Australian military officials were not able to change American personnel choices even if they disagreed with them.

Importantly, it was not only the Japanese diaspora, including individuals of mixed Japanese heritage, who were prohibited from enlisting in the Australian military during World War II. As the Defence Act 1909 excluded from enlistment any persons not of substantial European heritage, this also extended to racial minorities such as Aboriginal and Torres Strait Islanders and Chinese-Australians. However, despite the legal barrier, a great number of non-European Australians did enlist, including over 1,300 Indigenous Australians and 200 Chinese-Australians (AWM n.d.[a]). ${ }^{12}$ By 1942, the AIF became more desperate for recruits, and rules were informally relaxed to allow enemy aliens who were not perceived as a security threat to volunteer for service. However, this policy shift still excluded all Japanese, even while many Chinese-Australians were permitted to enlist (Clyne et al. 2015, 32; Beaumont et al. 2008, 5-6). Amendments to the Defence Act in 1943 also allowed for a more relaxed approach when it came to recruiting Aboriginal and Torres Strait Islander applicants, primarily due to the need for more men (Londey 2015). A similar relaxation of rules for Nikkei-Australians was generally not applied, largely because of Japan's status as an enemy of Australia. Thus, it was not simply the fact that Nikkei-Australians were non-European, nor that they were enemy aliens, but rather a combination of both that prohibited them from serving.

Historically, the experiences of Chinese-Australian and Indigenous Australian soldiers, like those of Nikkei-Australians, have largely gone uncelebrated (Baker et al. 2017). Recently, however, the centenary of World War I has helped to provide a platform for the stories of Chinese-Australian soldiers such as Billy Sing and Caleb Shang, and Indigenous Australian soldiers such as Reginald Saunders, to be shared in the mass media (Yu 2017; Moremon n.d.). This has facilitated an awareness that non-European Australians also contributed to the war effort during the era of White Australia. The monument to Indigenous soldiers in Sydney's Hyde Park, which was commissioned by the City of Sydney and unveiled in 2015, is one example of a public act of 
acknowledgement following a call for greater consciousness of non-white soldiers (Kembrey 2015). ${ }^{13}$ However, the smaller size of the Japanese community, fewer known surviving soldiers, and fewer academic studies has meant that Nikkei-Australian soldiers have not received the same attention.

Overall, the Australian military took a very hard-line approach to keeping people of Japanese descent outside of its ranks. Multiple factors led to the small number of Nikkei-Australians serving in the AIF, and racial ideas within Australia questioned the trustworthiness of anyone with Japanese blood. Together, these elements made it very difficult for Nikkei-Australians to successfully enlist in the AIF, and to remain soldiers after Japan entered the war. This is illustrated in the biographical accounts of the three NikkeiAustralian soldiers presented below.

\section{BIOGRAPHIES OF NIKKEI-AUSTRALIAN SOLDIERS}

\section{Mario Takasuka}

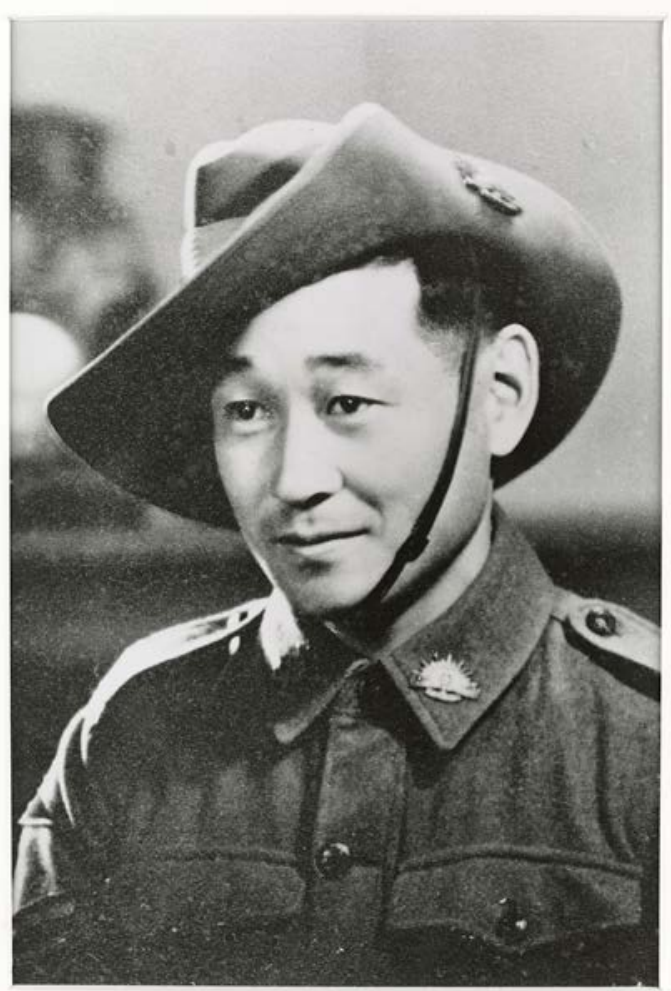

Figure 1: "Mario [Takasuka] on leave in Cairo, 1941" (Source: Building a Country Archive, Pictures Collection, State Library of Victoria. Accession number: H92.400/96)

Born in Swan Hill in 1910, Mario Takasuka was a Nisei and the youngest of three children. His parents Jo and Ichiko Takasuka and older brother Sho arrived in Australia on March 13, 1905. Unlike typical Japanese immigrants of the time, the Takasuka family were university-educated and were of the samurai class. They were early pioneers of Australian-Japanese trade relations through the importation of Japanese art, and were also responsible for the growth of the rice industry in Australia due to Jo's experiments with rice 
cultivation in Australian soil (Sissons 1980). The Takasuka family were able to obtain entry into Australia despite the Immigration Restriction Act and were permitted to remain in Australia for an extended period because of their important cultivation research (Oliver 2008, 131). Before the war, Mario worked as an orchardist in Fosterville with his father. ${ }^{14}$

In 1940, Mario volunteered locally to join the AIF. After being rejected twice, he was eventually accepted by enlisting in Melbourne, where his background was unknown and the recruiting officer was also unaware of the military regulations regarding race (Hayman 1980). Mario initially served in Crete and Alexandria in the 2/3 Light Anti-Aircraft regiment (Sissons 1980). When Japan entered the war at the end of 1941, military authorities made strong efforts to remove him. An enquiry was ordered when "the presence of a full-blooded Japanese in the Australian army came to the attention of the Minister" (Sissons 1980). Mario was a well-regarded member of his unit, and his commanding officer successfully argued for his continued deployment, stating: "His record as a soldier both in and out of action has been exemplary and in consideration of his outstanding service in Crete, I selected him for promotion as a bombardier. He is most popular with the men in his [battalion] and the recent declaration of war against Japan has in no way affected his popularity or his ambition to serve" (NAA: B883, VX37123). Mario remained with his unit and went on to serve in Palestine (where he received a written commendation from his general for his efforts in a train crash rescue), and in New Guinea, after being promoted to gun sergeant (Hayman 1980; Sissons 1980; Lewis 2012). Mario returned from the war in 1945 and continued to live in Australia until his death in 1999, aged 89 (Bryant 1989, 6; 2nd/3rd Australian Light Anti-Aircraft Regiment Association 2011; State Library of South Australia 2017).

\section{Winston Ide}

Winston Phillip James Ide was born in 1914 to a Japanese silk importer named Hideichiro (Henry) Ide and his Australian wife Clara (Growden 2012). Nicknamed 'Blow' after a childhood habit, Winston was a member of the 1939 Australian National Rugby team, the Wallabies (Lane 2011). While on his way to tour with the Wallabies in England in September 1939, war broke out. Ide enlisted in the AIF on 1 July 1940 at Kelvin Grove, Queensland, inspired by what he had seen in Europe (NAA: B883, QX13648; Lane 2011; AWM 2013). He joined the field regiment and in 1941 was sent to Singapore as a bombardier in Unit 2/10 (AWM 2013).

In February 1942, Singapore fell to the Japanese. Ide was among those taken prisoner at Changi in the surrender. On May 14, he was dispatched to Burma with 'A Force', and for two years worked as a POW for the Japanese, building the Thai-Burma Railway. ${ }^{15}$ His family held grave fears that he would be singled out as a traitor. However, "despite his Japanese ancestry, Ide was treated no differently to his fellow prisoners. Like all Australian prisoners in Burma and 
Thailand he was ravaged by disease, malnutrition and overwork" (Blackburn 2012, 213; see also AWM 2013). It is unknown whether the Japanese military became aware of his origins. In 1944, Ide and over 1,300 other POWs boarded a Japanese cargo ship named the Rakuyo Maru to be transported to Japan (Blackburn 2012, 214). On September 12 of that year, under the impression they were intercepting cargo, the American submarine Sealion torpedoed the Rakuyo Maru, along with the Kachidoki Maru, another Japanese cargo ship which was carrying British POWs (Lane 2011; San Francisco Maritime National Park Association 2007).

Ide is thought to have drowned assisting fellow soldiers who could not swim. Despite calls from comrades to climb aboard a life raft, Ide apparently stayed back to help fellow POWs (Growden 2012). He was last seen floating in the water, calling out that he was uninjured but that "some of the boys had been hurt... [so] he would stick by them for a while" (AWM 2013). His body was sadly never recovered; however, he was commemorated at Labuan Memorial Cemetery in Malaysia, off the coast of Borneo, as one of the 1,559 POWs who perished in the dual sinking (NAA: B883, QX13648; AWM 2013). He was 29 years old.

Kevin Blackburn (author of Sportsmen of Changi) has pointed out that Ide "died without knowing that government officials of his country did not have the confidence in him and his family that his rugby union mates had" (Growden 2012). In fact, the Australian government had been investigating Ide for possible sympathies toward Japan due to his ancestry. He also died apparently unaware that his father had been interned at Hay (Growden 2012). Before departing for the war, he had announced his engagement to Heather Jean Reynolds; however, they were never married and he has no known descendants (Blackburn 2012, 32). To honour his memory, in 1947 the Blow Ide Cup was established, and was played between Sydney rugby teams involving Ide's friends and colleagues (Blackburn 2012, 216). In 2013, there was also a Last Post Ceremony held at the Australian War Memorial in his honour. A memorial written by his friends reads: "Blow Ide died as he had always played-for his team" (Blackburn 2012, 216).

According to Blackburn, Ide is seen as a rugby role model in modern-day Japan, partly as a result of promotion by Japan's Rugby League Association (Blackburn 2012, 253). His story inspired the Japanese novel "The Fatal Full-Time” (死に至るノーサイド), a fictionalised account of Ide’s life written by Tsutomu Kaniya (蟹谷 勉), which was adapted into a TV documentary entitled “Did You Hear The Full-Time Whistle?” (君はノーサイドの笛を聞いた か) in 2010 (Kaniya 1993; “Kimi wa nōsaido" 2009). He also features in the book Sportsmen of Changi (Blackburn 2012), which examines the lives of Australian sportsmen who became POWs. Ide is believed to be one of three Nikkei soldiers from the Allied Forces to have become a Japanese POW; the other two were Nikkei-Americans Frank Fujita and Richard Sakakida (Fujita 1993; Densho 2017). Due to his rugby connections, Ide is probably the most widely known Nikkei-Australian to have fought in World War II. 


\section{Joseph Suzuki}

Joseph was born Ichero Shibuya in Mikage, in the Japanese city of Kobe on February 28, 1922, and migrated to Australia with his Australian mother Ada May Suzuki (née Quinn, also known as Ada May Shibuya) and sister Hannah just after his birth. ${ }^{16}$ Joseph's father was a Japanese ship captain named Harohiko Shibuya; the family name of Joseph and his siblings became Suzuki after his mother's second marriage to Sakuhei Suzuki (Oliver 2002). Joseph was an apprentice surveyor at the time of his enlistment. On June 19, 1940 he registered for service in the AIF in Sydney, falsely listing his birthplace as Geelong and his name as Joseph Suzuki (his first name was still legally Ichero), as well as raising his age to twenty-two (NAA: B883, NX32903). On his enlistment experience, he is quoted as saying, "I was only seventeen. I knew that I was entitled to serve Australia" (Nagata 1996, 106). Joseph served in the 2/1 Survey Regiment in Australia until February 21, 1941, when his identity was discovered. He was discharged "on racial grounds", and went back to his previous employer to continue working as a surveyor until he was interned at Hay on December 8, 1941 (NAA: MP529/3, TRIBUNAL 4/46).

Suzuki fought tirelessly to prove his loyalties to the Australian government so that he could be released from internment. He submitted an application for release, and went before a tribunal on May 13, 1942. There he emphasised his desire to assist the war effort in any way he could, including being prepared to take the risk of being "taken prisoner... [or] shot as a traitor" (NAA: B883, NX32903). According to Oliver (2002), Suzuki and his sister, who had her own tribunal to contend with, saw themselves as Australians (282). Joseph even had a tattoo of a map of Australia (NAA: MP1103/2, NJ17051). He and his sister were supported by their community, who testified on their behalf. The Commanding Officer at Woolenook Wood Camp, where Suzuki was interned for some time, also aided his case, stating: "He is 100 percent Australian, hates the Japs and will not associate with them" (Nagata 1996, 106). Suzuki later explained in an interview for The Sunday Telegraph that he was "an Australian to the backbone" (Nagata 1996, 108).

Although the tribunal concluded in 1942 that Suzuki should be released, he remained interned until August 21, 1944 (NAA: D4028, SUZUKI JOSEPH). This was apparently due to reports from the Australian Military Forces (AMF) Eastern Command in July 1942 which argued that as a person with Japanese heritage born in Japan, Joseph was under "the influence of the fatalistic Emperor cult; [and] the obligation on Japanese to report intelligence to the Consulate," and that "evidence of conversion to Christianity was no argument for Australian orientation" (Oliver 2002, 285). The military was also concerned that his skills as a surveyor would be useful to the enemy (Nagata 1996, 107). Further, his Security Service assessment presented to the government argued that "the son of a Japanese is always regarded as a Japanese even if he had some other nationality" (Haid 2011, 168). Because of his prolonged internment, Suzuki suffered mentally and was hospitalised. This eventually led to his release (Haid 2011, 168). He and several of the other 'mixed race' or Australian-born internees did not get along with the Japanese nationals 
in the camp. They were referred to as 'The Gang' and were segregated in a separate tent (Nagata 1996, 107, 175). Suzuki himself said the other internees were friendly enough, but they had to "try to speak English" to communicate with him, as he did not speak any Japanese (NAA: MP529/3, TRIBUNAL 4/46). Suzuki's actions at Hay appear to have served as the inspiration for a fictional character named Peter Suzuki in After Darkness, an Australian novel based around Japanese internment at Loveday in South Australia (see Piper 2014, 63-65).

After his release, Suzuki returned to Newcastle, where he was naturalised on June 12, 1945 (NAA: A714, 29/11866). He also eventually changed his surname to his mother's maiden name due to continued discrimination. In Nagata's Unwanted Aliens (1996), Joseph's sister Hannah is recorded as stating that she did not wish for Joseph to be contacted for research, as it would upset him too much (235). No date of death has been located due to difficulty confirming his full legal name.

\section{DISCUSSION AND ANALYSIS}

Official treatment of Nikkei-Australians in the 1940s was heavily influenced by the White Australia Policy and the outbreak of World War II. The term 'Australian-born Japanese', appearing in official documentation from the time, indicates that Nikkei-Australians were not officially recognised as "real" Australians (Haid 2011, 128). Not only were they seen as foreign, but they faced further discrimination because they shared the same heritage as the enemy. Interestingly, this did not result in the three Nikkei-Australians above turning away from the country that rejected them, nor did it sway them from enlisting. Instead, they made the decision to fight for a country that imprisoned their families and distrusted them, even going so far as to falsify information or attempt to enlist multiple times, because they believed it was their duty and right as Australians-evidenced by Suzuki's assertion that he "was entitled to serve Australia" (Nagata 1996, 106). In doing this, they went against the stereotypes and assumptions held by the government and the greater Australian community, as exemplified by the White Australia Policy and Pearson's and Barnwell's racial theories, which popularised the idea that Nikkei could not assimilate.

The analysis that follows investigates the links between Nikkei-Australian identity and treatment of Nikkei-Australians by the Australian government and their local communities during World War II, looking at the schisms between three different images of Nikkei-Australians: how Nikkei were seen bureaucratically and legislatively, how they were seen by their local communities and peers, and how they saw themselves. This discussion will also draw on the experiences of the Japanese diaspora serving in the military in Canada and the United States, as well as Australian soldiers of non-Nikkei racial minority backgrounds, which have been more substantially documented and researched than those of their Australian counterparts. ${ }^{17}$ 
The three Nikkei-Australian soldiers chosen for this study enlisted at a time when Australian identity was often linked with race-particularly in legislation, where the Australian community was defined "in terms of colour" (Haid 2011, 61). However, those who identified as both Australian and Japanese, or who identified as Australian but looked outwardly Japanese, did not fit the stereotypes of 'foreignness' prevalent in Australian society at the time. These stereotypes served to conflate Nikkei-Australians with the soldiers in the Japanese military that Australia witnessed during wartime, who were regarded as "subhuman beast[s]" and "vermin" (Saunders 1994, 325-27). Moreover, they were thought of as being absolutely loyal to Japan (Oliver 2002, 275).

However, the experiences of these Nikkei-Australian soldiers during and before the war suggest that they considered themselves Australian, or at least outwardly identified as such. In particular, Japanese-born Joseph Suzuki appears to have identified strongly as Australian and distinctly not as Japanese. This is highlighted by his own reported assertion that he was "Australian to the backbone", and is reinforced by other indications such as his refusal to mingle with Japanese nationals during internment, and potentially also his Australia map tattoo (Nagata 1996, 105-8). His sister spoke of him as always being "a loyal Australian. The proof is that he got a medal from the Queen” (Nagata 1996, 235). Similarly, his mother testified that he had pro-Australian views (Oliver 2002, 285).

Statements made by Mario Takasuka also suggest that he felt stronger sympathies towards Australia, where he was born and raised, than to his familial ties to Japan. Takasuka is described by Sissons (1980) as "a man of strong patriotic sentiment" toward Australia, and evidence suggests this may be true (168). Of the Japanese influence on his upbringing, Takasuka had this to say:

My mother...brought us up on part Japanese food. Well, English-Japanese food, because she had to cook it on a wood stove and that sort of thing... We kids never learned to use chopsticks. We always used knives and forks... Father was a typical Japanese father... Both father and mother sang Japanese songs and they would make up verses and rhymes to celebrate something or designate something, or whatever. It seemed to be part of their upbringing... [Mother] played the Japanese instruments that we had there in those early days... I don't know what they were called.

(Lewis 2012, 31-32)

His words portray a typical country Australian upbringing with some Japanese cultural influence. His lack of knowledge regarding the Japanese music and songs of his parents seems to indicate a disinterest in and disconnect from his parents' culture, suggesting that he too may have identified more strongly with Australia than with his Japanese heritage. There are fewer primary sources relating to how Winston Ide self-identified, however the fact that he never made his heritage known to Japanese authorities during his time as a POW does suggest an allegiance to the Australian military. 
This corroborates the findings of research on North-American Nikkei which shows that Nikkei soldiers were often raised in multicultural environments, and identified with the country they were raised in. In the US, for example, many Nikkei-American soldiers saw themselves as American while still preserving their cultural and emotional ties to Japan (O 2011, 121-23, 204). Many put more weight on their non-Japanese heritage, outwardly appealing to be recognised as a part of their immediate local communities. Nikkei-Canadian soldiers, like their Australian and American counterparts, emphasised their love for Canada and their desire to be recognised as Canadians (Ito 1984, 164). Clark and Russell (1945) assert that Nikkei-American soldiers resented being set apart from other Americans and being called "Japs" or "Yank-Japs"; they preferred to simply be called "American" (701). ${ }^{18}$ This is a clear indication of their stronger associations with the country they were raised in, and a desire to be recognised as a part of that country without qualification.

Nikkei soldiers abroad saw enlistment as a way of proving their loyalty to, and achieving equality as citizens of, the countries where they were raised. Roy Ito's We Went To War (1984) asserts that in Canada, the Japanese diaspora joined the military to fight for the rights of Nikkei-Canadians, prove that they were loyal and thereby fight against governmental discrimination (8). ${ }^{19}$ Likewise, many Nikkei-Americans enlisted in military service to prove that they were good Americans and "basically no different in attitude or loyalty from American citizens whose forebears came from other lands" (Clark and Russell 1945, 698). Ken Ishii (2008), a Nikkei-British man who was drafted into the Japanese army, affirms this, stating, "In war you were forced to choose where your loyalties lay" (22).

Another common reason for enlistment was related to internment. In the US, some Nikkei-American internees were given the choice to serve in the military rather than continue their internment, providing an opportunity for freedom or variety in life that was denied while they were interned (Maranzani 2011). Some internees enlisted because they believed that their similarly interned families would be treated more favourably, or be given a better chance of release $(\mathrm{O}$ 2011, 210). In Australia, other non-European soldiers had similar reasons for enlistment. For many Indigenous Australians, the military was the first environment where they experienced equal treatment, as they were entitled to the same wages as non-indigenous soldiers. According to John Moremon from the Australian Department of Veterans' Affairs, they felt a sense of equality in serving, and joined in the hope that their service would help to advance equality and improve the chances of Indigenous Australians achieving citizenship during peacetime (Moremon n.d.). Others joined out of fear of being ostracised for "staying behind", or because they "believed the war was just; others sought adventure, good pay, or joined up because mates did", just as many European-Australians decided to do (Moremon n.d.). 
Did these reasons apply to the three individuals chosen for this paper? It is impossible to say. However, early releases from internment were granted by the Australian government to some Nikkei-Australian internees, and an examination of these early release cases presented in Nagata's (1996) research shows that the Australian army did give special consideration to internees whose family members had enlisted. This included Winston Ide's father Henry, who was released from Hay in 1942 (Nagata 1996, 103-8). Based on this, we can tentatively conclude that for some, the possibility of family members' release from internment may have been a factor behind the decision to enlist. Joseph Suzuki's statement that he was "entitled" to serve may imply that he also desired equal recognition (Nagata 1996, 106). This, along with other previously stated gestures, suggests that like their North American and non-European Australian counterparts, Nikkei-Australians who enlisted may have done so as one way to fight for recognition, with entrance into the military a clear sign of being accepted as insiders in the community (Ito 1984).

\section{Nikkei-Australians and the State during World War II}

Born and raised at the height of the White Australia Policy's influence, the Nikkei-Australian soldiers chosen for this research were, as discussed above, greatly impacted by race-based legislation and ideas surrounding nationality. During the period the policy was in force, race was officially linked to the idea of Australian nationality, and the two ideas were often conflated (Haid 2011, 240-41). At the time, mixed births were generally perceived by the greater Australian public as impure at best, as "one drop" of foreign blood was considered enough to taint the purity of the White Australian ideal (Yazdiha 2010, 32). Thus, people were racially divided from both social and legal perspectives into those who were of pure European descent and those who were not. This is exemplified by the Defence Act 1909's exclusion of nonEuropean Australians from military enlistment discussed earlier. Ethnicity, as "the application of systematic distinctions between outsiders and insiders" created an 'us and them' mentality that was compounded by the war against Japan and had roots in fear and animosity towards the other (Eriksen 2010, 22). Acceptance of Nikkei-Australians in formal contexts and through official channels was determined on a case-by-case basis, complicated by inconsistent or selective treatment of race in legislation at the time. While in theory all Nikkei-Australians were excluded from military service as a result of their enemy alien heritage, in practice several variables came into play. As will be shown below, Nikkei-Australians were generally branded with one nationality or the other depending on several factors, including how recognisable their Japanese heritage was in terms of name, physical appearance, birthplace and patrilineage. How they personally identified appears to have had little bearing on their treatment officially, although it may have influenced their treatment within the local community.

In general, the government used patrilineage as the basis for identification of heritage. As can be seen in the laws on citizenship, the nationality of the father was considered more influential than that of the mother. Mario Takasuka, Joseph Suzuki and Winston Ide all had Japanese fathers, and thus could all mo 
be classified as aliens under the Aliens Registration Act. These laws linked children to their fathers' nationality and ethnicity. The proceedings of Joseph Suzuki's internment appeal provide an example of how this law was applied in practice. Character witnesses for Suzuki were mainly questioned about the influence of his Japanese step-father, Sakuhei Suzuki. This demonstrates that the government believed the father figure to be a dominant role model, despite the fact that the two were biologically unrelated in this case, and that Suzuki had been in the care of his Anglo-Australian mother as a child. In contrast with the rest of the Suzuki family, Sakuhei was vehemently anti-British and had allegedly threatened to shoot the family if Joseph enlisted in the Australian military (Oliver 2002; Nagata 1996, 104). The witnesses, however, testified that the Suzukis were brought up by their mother "the Australian way", and argued against any influence from their step-father's pro-Japanese views (Oliver 2002, 284-85). Similarly, the AMF Eastern Command argued that the Ide family had an "Australian outlook", and thus could not have been influenced by their father even if he had had pro-Japanese views (Oliver 2002, 281). The strong influence of Ide's mother was highlighted in his appeal and likely influenced the Australian military's decision to allow Winston and his brother to continue their service without internment.

Physical appearance also influenced how Nikkei-Australians were identified and treated by the authorities. The Defence Act 1909 included the vague wording "sufficiently European" (Nagata 1996, 105), creating a loophole that allowed some mixed-race individuals to enter the military. Ide, who had mostly Caucasian features, appears to have not been identified as Nikkei by either Australian or Japanese officials at the time of his enlistment. Those with more Japanese features, such as Takasuka, had more documented difficulty enlisting than Ide. This seems to suggest that physical appearance, rather than genetic makeup, is how the military determined 'European-ness'.

Names were another point of difference to which Nikkei-Australians experienced reactions of varying intensity. Documents about the Ide family sometimes show 'Ide' spelt as the English surname "Eady", which suggests either that it was not immediately recognised as a common Japanese name at the time, or perhaps that the Ide family may have consciously adopted an Anglicised spelling for convenience. Whatever the case, the dual spellings were picked up by officials, with intelligence correspondence revealing an urgent request for more information on Ide's brother Roy, as "the English name of Eady might be misleading" (NAA: C123, 18502). Other Nikkei-Australians experienced significant difficulties as a result of their Japanese surnames. For example, Nikkei-Australian Moto Kozo Hasegawa, whose brother was a Nikkei-Australian soldier, "had had enough of being called a 'Jap' and decided that the easiest thing for him and his family was to adopt his ...mother's maiden name, Cole", as "WW2 was a difficult time, [and] the name Hasegawa along with Asian looks brought the worst out in some people but not all" (Hasegawa 2014). Joseph Suzuki also changed his name after the war, stating that "my present surname causes considerable embarrassment both to myself and my employers" (Nagata 1996, 108). ${ }^{20}$ Thus, names were one indication of Japanese heritage that the military used to identify enemy aliens, 
and the stigma attached to Japanese names appears to have carried over into the greater community and lingered following the end of the war.

Birthplace was another important factor, as it affected visa status and perceptions of national loyalty among officials. Suzuki is the only known Nikkei soldier to have been born in Japan, and was treated differently as a result (NAA: D4028, JOSEPH SUZUKI). He would have been a British citizen had he been born three months later, after his family had migrated, but the timing of his birth proved to be a determining factor in his treatment as an adult, and the chairman at his tribunal stated as much (Oliver 2002, 285; NAA: MP529/3, TRIBUNAL 4/46). Suzuki's discharge from the army and subsequent internment was at odds with the treatment of the other Nikkei-Australian soldiers profiled in this paper, suggesting that his birthplace influenced these outcomes. This is corroborated by the fact that Mario Takasuka's older Japanese-born brother Sho was unable to enlist in the military, and indicates that place of birth was considered more important than heritage in determining nationality and loyalty.

Despite their histories of military service, Nikkei-Australian soldiers experienced discrimination both during and after World War II. This is most evident in the lengths that some went to in order to hide their heritage or avoid prejudice, including changing their names. Suzuki's own anti-Japanese sentiment, evident in earlier quotes regarding his time in internment, may also have led to a desire to distance himself from his Japanese heritage in this way. Indigenous, Chinese and other non-European Australian veteran soldiers faced similar battles. Indigenous Australians were seen as disloyal and "contaminated by Japanese propaganda", and thus were perceived as potential collaborators with the Japanese and untrustworthy as allies (Saunders 1994, 326-29). Although many Indigenous Australians enlisted in the hope of effecting change to their citizenship rights, they received negligible recognition for their war efforts, and racism continued to permeate Australian society (Moremon n.d.). Furthermore, they were denied citizenship rights by the government until 1967, over two decades after the war ended. Chinese-Australian soldier Jack Goon reflects on a similarly mixed experience: "You got a lot of this 'Ching-Chong Chinaman' business, but it didn't worry me. Wearing uniform gave you a lot of confidence and a lot of pride" (Hui 2002; see also Moremon n.d.).

In the US, Nikkei-American soldiers were heralded as heroes after the war, which helped to sway public opinion on Americans of Japanese descent. As Clark and Russell (1945) state, "their achievements do more than volumes of propaganda could to demonstrate that democracy is stronger than race" (698). Despite this, Nikkei-American soldiers were treated poorly by some members of the public-including being refused service or denied work (Clark and Russell 1945, 703). While their war efforts helped to gradually shift perceptions and win over the public, it is clear that Nikkei-Americans and non-European Australians, including Nikkei-Australians, still faced discrimination from their respective governments and national communities following the war. 
While the White Australia Policy and wartime propaganda encouraged anti-Japanese sentiment, it did not appear to have a strong influence on the relationships between Nikkei-Australians and their local communities at an individual level. Many accounts suggest that the Nikkei-Australian population had integrated well into Australian communities (Oliver 2007). Due to the tightening of immigration restrictions post-1901, the majority of Nikkei-Australian families had been living in Australia for four decades by the time World War II broke out. They were therefore likely to have been well established in their respective local communities and would not have been a new or alien presence. This may have contributed to the fact that, while discrimination and racism certainly existed (especially on a policy level), local community attitudes were far more diverse. ${ }^{21}$ As explored below, the relationships between Takasuka, Ide and Suzuki and their local communities indicate that white Australians valued Japanese immigrants as good citizens with similar family values and work ethics. It was the Australians who did not have contact with Nikkei-Australians who continued to fuel anti-Japanese sentiment and encourage the official stance that Nikkei-Australians were Japanese, and not Australian (Haid 2011, 222).

During the war, the 'alien' identity ascribed to Nikkei-Australians bureaucratically was at odds with their acceptance by the immediate community (Haid 2011, 36). This schism is shown by the support that NikkeiAustralian internees received from their local communities. For example, Joseph Suzuki and his family were granted release from internment based on statements from community figures who willingly attested to their good character. The Mayor of Geelong testified that Suzuki's half-Japanese grandfather, also interned, was a "well-known, trusted and leading citizen" (Oliver 2002, 284). This and other testimonies were substantial enough to have an impact on Suzuki's release, with the chairman of his tribunal stating that "he has kept very good company and gives very good references" (NAA: MP529/3, TRIBUNAL 4/46). Similarly, Mario Takasuka and his family also received endorsements from people close to them. A statement from his commanding officer attested to the trust he had built with his military colleagues, while at his brother Sho's tribunal, the family reputation was described by neighbours as "absolutely one of the best" (NAA: MP529/3, TRIBUNAL 4/110). The Swan Hill police force felt ashamed and embarrassed at the prospect of arresting the Takasuka family, who were a part of the community, and sought advice from the attorney-general about circumventing the regulations (Oliver 2008, 137-39). The Takasuka family's strong reputation helped to keep not only Mario but also his mother Ichiko and sister Aiko Watters (née Takasuka) out of internment (Nagata 1996, 57). The early release of Winston Ide's father Henry from internment in October 1942 was also influenced by his presence in the community, along with his son's military service. After his release, security service officers reported "positive views of neighbours who respected Ide and welcomed his return" (Oliver 2002, 282). These examples of early release corroborate Oliver's research on the support of Nikkei-Australians by white Australian communities. Local support, 
according to Oliver, was "important in weighing whether a person's release would cause unrest in the community" (Oliver 2002, 284). Although racism in local communities did exist, these examples demonstrate that people who knew Nikkei-Australians showed support for those individuals' freedom at a time when the government declared them enemy aliens.

In general, the treatment of Nikkei-Australian soldiers varied noticeably, case by case. These variations were largely based on coincidental opportunities, circumstances of birth, physical appearance and family background. Takasuka, who had two Japanese parents, and Japanese-born Suzuki had more documented difficulties with regulations and discrimination than did Ide, ostensibly due to their different parentage, birth places and more distinct Japanese features. However, all three families were accepted by their local communities, indicating that their family backgrounds and physical appearance had little bearing on the support they received from their peers. While Nikkei-Australians diverged from the white Australian ideal of racial homogeneity (Collins 2012, 117), the words and actions of the soldiers discussed in this section suggest that they identified as Australians, even if the legal status of their nationality was vague. This also aligns with the documented experiences of North-American Nikkei soldiers and other non-European Australian soldiers during World War II. Despite the prevalence of racism within the government and greater Australian community towards Japanese immigrants and their descendants during World War II, evidence shows that Nikkei-Australians did assimilate, and that their local communities accepted them (Oliver 2002, 276).

\section{CONCLUSION}

This study has explored the stories of three Nikkei-Australian soldiers and their wartime experiences. While these experiences were all distinct and varied, we can draw several conclusions based on their similarities and differences. Firstly, the treatment of Nikkei-Australian soldiers by military and government officials significantly differed from how they were treated by their own communities and peers. While government rhetoric sought to position the Nikkei population as outsiders who were separate from, and a threat to, Australian society, the examples explored in this paper provide evidence that Nikkei-Australians were accepted by their communities and were respected and valued members of society. Furthermore, attitudes within local communities were much more varied than the bipartisan support of the political establishment for immigration restriction. Legislatively, the three Nikkei-Australians at the centre of this study were ambiguously positioned at best and enemy aliens at worst. Nonetheless, socially they displayed evidence of identifying as Australian and were accepted as such within their local communities.

While the scope of this study is limited in focus to the archival documents of three individuals, there is potential for further research. Seventeen NikkeiAustralians soldiers have been identified to date, but there may be more. 
In bringing to light the important stories of Nikkei-Australian community members who served in the armed forces and highlighting how their experiences differed from those of white Australians both legally and socially, we can delve into attitudes towards Australian identity and perceptions of Japan during World War II. Even while anti-immigration and anti-Japanese policies were in force and race-based conceptions of national identity were prevalent, the lives of the three soldiers examined in this study provide evidence that Nikkei-Australians were accepted as compatriots by their peers. With the recent increased interest in non-white Australian military history, the author hopes that this paper will bring to light these little-known NikkeiAustralian stories. These stories are important for recognition of the individual contributions of non-white Australian soldiers during World War II. Further, they highlight that, even during the era of the White Australia Policy, nonwhite immigrants not only lived in Australia but also identified strongly as Australian and integrated successfully into their communities.

\section{GLOSSARY}

\section{AIF}

Australian Imperial Force. This was the main force of the Australian military, and was made up exclusively of volunteers. The First AIF served in World War I and the Second AIF served in World War II.

AMF

Australian Military Forces

AWM

Australian War Memorial

Issei (一世)

First-generation Japanese-born immigrants

Nikkei (日系)

Members of the Japanese diaspora and their descendants

Nikkei-Australians

Japanese migrants to Australia and their Australian-born descendants

Nisei (二世)

Members of the second generation of the Japanese diaspora, born outside of Japan to Japanese (Issei) parents

POW

Prisoner of war

NAA

National Archives of Australia, accessible online at http://naa.gov.au/ 
APPENDIX: LIST OF KNOWN NIKKEI WHO SERVED IN THE AUSTRALIAN MILITARY IN WORLD WAR II

\begin{tabular}{|c|c|c|c|c|c|c|}
\hline & $\begin{array}{l}\text { Name } \\
\text { (Ordered } \\
\text { alphabetically } \\
\text { by family } \\
\text { namel }\end{array}$ & $\begin{array}{l}\text { Birthplace } \\
\text { and Date of } \\
\text { Birth (DOB) }\end{array}$ & $\begin{array}{l}\text { Enlistment } \\
\text { Location }\end{array}$ & $\begin{array}{l}\text { Military } \\
\text { Division } \\
\text { and } \\
\text { Service } \\
\text { Number }\end{array}$ & $\begin{array}{l}\text { Japanese } \\
\text { Heritage }\end{array}$ & Reference \\
\hline 1 & $\begin{array}{l}\text { Son of Okin and } \\
\text { Siam Ahmat } \\
\text { (name } \\
\text { unknown) }^{+}\end{array}$ & $\begin{array}{l}\text { Cossack, WA } \\
\text { or Onslow, } \\
\text { WA } \\
\text { (DOB } \\
\text { unknown) }\end{array}$ & Unknown & Unknown & $\begin{array}{l}\text { Japanese } \\
\text { mother, } \\
\text { Thai father }\end{array}$ & $\begin{array}{l}\text { Nagata } \\
1996,58\end{array}$ \\
\hline 2 & $\begin{array}{l}\text { George Mason } \\
\text { Furuya }\end{array}$ & $\begin{array}{l}\text { Prahran, VIC } \\
\text { Dec 26, } 1904\end{array}$ & $\begin{array}{l}\text { Caulfield, } \\
\text { VIC }\end{array}$ & $V \times 27226$ & $\begin{array}{l}\text { Japanese } \\
\text { father }\end{array}$ & $\begin{array}{l}\text { NAA: } \\
\text { B883, } \\
\text { VX27226 }\end{array}$ \\
\hline 3 & Leo Hasegawa & $\begin{array}{l}\text { (Birthplace } \\
\text { unknown) } \\
\text { Dec 21, } 1905\end{array}$ & $\begin{array}{l}\text { Geelong, } \\
\text { VIC }\end{array}$ & CMF & $\begin{array}{l}\text { Japanese } \\
\text { father }\end{array}$ & $\begin{array}{l}\text { NAA: } \\
\text { CT190/19, } \\
\text { 10/49 }\end{array}$ \\
\hline 4 & Harry Ide & $\begin{array}{l}\text { Sydney, NSW } \\
\text { Jan 17, } 1902\end{array}$ & $\begin{array}{l}\text { Paddington, } \\
\text { NSW }\end{array}$ & $\begin{array}{l}\text { AlF } \\
\text { NX66702 }\end{array}$ & $\begin{array}{l}\text { Japanese } \\
\text { father }\end{array}$ & $\begin{array}{l}\text { NAA: } \\
\text { B883, } \\
\text { NX66702 }\end{array}$ \\
\hline 5 & Winston Ide* & $\begin{array}{l}\text { Sydney, NSW } \\
\text { Sep 17, } 1914\end{array}$ & $\begin{array}{l}\text { North } \\
\text { Sydney, } \\
\text { NSW }\end{array}$ & $\begin{array}{l}\text { AlF } \\
\text { QX13648 }\end{array}$ & $\begin{array}{l}\text { Japanese } \\
\text { father }\end{array}$ & $\begin{array}{l}\text { NAA: } \\
\text { B883, } \\
\text { QX13648 }\end{array}$ \\
\hline 6 & Francis Ito & $\begin{array}{l}\text { Geelong, VIC } \\
\text { Jan 28, } 1917\end{array}$ & $\begin{array}{l}\text { Geelong, } \\
\text { VIC }\end{array}$ & V167421 & $\begin{array}{l}\text { Japanese } \\
\text { father }\end{array}$ & $\begin{array}{l}\text { NAA: } \\
\text { B884, } \\
\text { V167421 }\end{array}$ \\
\hline 7 & $\begin{array}{l}\text { Selby Sakechi } \\
\text { Okamura }\end{array}$ & $\begin{array}{l}\text { Brisbane, } \\
\text { QLD } \\
\text { Jan 10, } 1911\end{array}$ & $\begin{array}{l}\text { Brisbane, } \\
\text { QLD }\end{array}$ & $\begin{array}{l}\text { AlF } \\
\text { QX35217 }\end{array}$ & $\begin{array}{l}\text { Japanese } \\
\text { father }\end{array}$ & $\begin{array}{l}\text { NAA: } \\
\text { B883, } \\
\text { QX35217 }\end{array}$ \\
\hline 8 & $\begin{array}{l}\text { Kazu (Kaz) } \\
\text { Milton Omaye }\end{array}$ & $\begin{array}{l}\text { Parramatta, } \\
\text { NSW } \\
\text { Nov 24, } 1923\end{array}$ & $\begin{array}{l}\text { Strawberry, } \\
\text { WA }\end{array}$ & NX139932 & $\begin{array}{l}\text { Japanese } \\
\text { father }\end{array}$ & $\begin{array}{l}\text { NAA: } \\
\text { B883, } \\
\text { NX139932 }\end{array}$ \\
\hline
\end{tabular}

\section{Notes}

* Case study examined in this paper.

† It is possible that this soldier is Patrick Ahmat, whose name is recorded in Nagata (1996). However, as I have been unable to corroborate this or find any military records to confirm whether the book refers to him or a brother, I have listed him this way. 
APPENDIX: LIST OF KNOWN NIKKEI WHO SERVED IN THE AUSTRALIAN MILITARY IN WORLD WAR II (CONTINUED)

\begin{tabular}{|c|c|c|c|c|c|c|}
\hline 9 & $\begin{array}{l}\text { Tomo (Tom) } \\
\text { Kevin Omaye }\end{array}$ & $\begin{array}{l}\text { Parramatta, } \\
\text { NSW } \\
\text { Feb 25, } 1925\end{array}$ & $\begin{array}{l}\text { Sydney, } \\
\text { NSW }\end{array}$ & NX178247 & $\begin{array}{l}\text { Japanese } \\
\text { father }\end{array}$ & $\begin{array}{l}\text { NAA: } \\
\text { B883, } \\
\text { NX178247 }\end{array}$ \\
\hline 10 & $\begin{array}{l}\text { Albert Joseph } \\
\text { Miller Dicinoski }\end{array}$ & $\begin{array}{l}\text { Brisbane, } \\
\text { QLD } \\
\text { Sep 21, } 1924\end{array}$ & $\begin{array}{l}\text { Redbank, } \\
\text { QLD }\end{array}$ & Q270458 & Unknown & $\begin{array}{l}\text { NAA: } \\
\text { B884, } \\
\text { Q270458 }\end{array}$ \\
\hline 11 & $\begin{array}{l}\text { Joseph } \\
\text { Dicinoski }\end{array}$ & $\begin{array}{l}\text { Glen Innes, } \\
\text { NSW } \\
\text { Feb 23, } 1904\end{array}$ & $\begin{array}{l}\text { Kelvin } \\
\text { Grove, QLD }\end{array}$ & Q265679 & $\begin{array}{l}\text { Japanese } \\
\text { grandfather }\end{array}$ & $\begin{array}{l}\text { NAA: } \\
\text { B884, } \\
\text { Q265679 }\end{array}$ \\
\hline 12 & $\begin{array}{l}\text { Ronald } \\
\text { Reginald } \\
\text { Dicinoski }\end{array}$ & $\begin{array}{l}\text { Charleville, } \\
\text { QLD } \\
\text { Dec 29, } 1924\end{array}$ & $\begin{array}{l}\text { Brisbane, } \\
\text { QLD }\end{array}$ & $\begin{array}{l}\text { RAAF } \\
\text { AC435239 }\end{array}$ & $\begin{array}{l}\text { Japanese } \\
\text { great- } \\
\text { grandfather }\end{array}$ & $\begin{array}{l}\text { NAA: } \\
\text { A9301, } \\
435239\end{array}$ \\
\hline 13 & $\begin{array}{l}\text { Zelda Winifred } \\
\text { Dicinoskił }\end{array}$ & $\begin{array}{l}\text { Charleville, } \\
\text { QLD } \\
\text { Jan 9, } 1927\end{array}$ & $\begin{array}{l}\text { Brisbane, } \\
\text { QLD }\end{array}$ & $\begin{array}{l}\text { RAAF } \\
\text { W102610 }\end{array}$ & $\begin{array}{l}\text { Japanese } \\
\text { great- } \\
\text { grandfather }\end{array}$ & $\begin{array}{l}\text { NAA: } \\
\text { A9301, } \\
102610\end{array}$ \\
\hline 14 & $\begin{array}{l}\text { Ichero (Joseph) } \\
\text { Suzuki* }\end{array}$ & $\begin{array}{l}\text { Kobe, Japan } \\
\text { Feb 28, } 1922\end{array}$ & $\begin{array}{l}\text { Paddington, } \\
\text { NSW }\end{array}$ & $\begin{array}{l}\text { AlF } \\
\text { NX32903 }\end{array}$ & $\begin{array}{l}\text { Japanese } \\
\text { father }\end{array}$ & $\begin{array}{l}\text { NAA: } \\
\text { B883, } \\
\text { NX32903 }\end{array}$ \\
\hline 15 & $\begin{array}{l}\text { Mario } \\
\text { Takasuka* }\end{array}$ & $\begin{array}{l}\text { Swan Hill, } \\
\text { VIC } \\
\text { Nov 15, } 1910\end{array}$ & $\begin{array}{l}\text { Royal Park, } \\
\text { VIC }\end{array}$ & $\begin{array}{l}\text { AIF } \\
\text { VX37123 }\end{array}$ & $\begin{array}{l}\text { Japanese } \\
\text { mother and } \\
\text { father }\end{array}$ & $\begin{array}{l}\text { NAA: } \\
\text { B883, } \\
\text { VX37123 }\end{array}$ \\
\hline 16 & $\begin{array}{l}\text { Arthur } \\
\text { Yamaguchi }\end{array}$ & $\begin{array}{l}\text { Burketown, } \\
\text { QLD } \\
\text { Jan 11, } 1921\end{array}$ & $\begin{array}{l}\text { QLD (exact } \\
\text { location } \\
\text { unknown) }\end{array}$ & $\begin{array}{l}\text { North } \\
\text { Australia } \\
\text { Observer } \\
\text { Unit } \\
\text { Q230474 }\end{array}$ & $\begin{array}{l}\text { Japanese } \\
\text { father }\end{array}$ & $\begin{array}{l}\text { NAA: } \\
\text { B884, } \\
\text { Q230474; } \\
\text { Nagata } \\
1996,58 .\end{array}$ \\
\hline 17 & William Yoshida & $\begin{array}{l}\text { Brisbane } \\
\text { QLD } \\
\text { May 12, } 1917\end{array}$ & $\begin{array}{l}\text { Brisbane, } \\
\text { QLD }\end{array}$ & $\begin{array}{l}\text { CMF } \\
\text { Q28843 }\end{array}$ & $\begin{array}{l}\text { Japanese } \\
\text { father }\end{array}$ & $\begin{array}{l}\text { NAA: } \\
\text { B884, } \\
\text { Q28843 }\end{array}$ \\
\hline
\end{tabular}

Notes

$\ddagger$ Zelda Dicinoski is the only known female Nikkei-Australian to have joined the military during World War II. She served as a clerk/typist for the Australian and US Air Forces. 


\section{REFERENCES}

\section{Primary Sources}

The following sources can be found through the National Archives of Australia.

\section{Winston Ide}

NAA: A8231, 18/IDE WINSTON PHILLIP JAMES

NAA: B883, QX13648

NAA: C123, 18466

NAA: J1193, QX13648

Information about his family can be found in:

NAA ACT: A367/1, C69851 and A367/1, C69304

NAA VIC: MP529/3, 4/74

NAA: C123, 18467; MT1486/1; C123, IDE/HARRY; C123, 18458 and $\mathrm{C} 123,18502$

\section{Mario Takasuka}

NAA: B883, VX37123

Information about his family can be found in:

NAA ACT: A1/15, 25/27797 and A659, 1940/1/5346

NAA VIC: MP729/6, 65/501/147 and MP529/3, 4/110

\section{Joseph Suzuki}

NAA: D4028, SUZUKI JOSEPH

NAA: B883, NX32903

NAA: MP1103/1, NJ17051

NAA: MP1103/2, NJ17051

NAA: A714, 29/11866

NAA: MP529/3, TRIBUNAL 4/46

Information about his family can be found in:

NAA ACT: A367/1, C66204; A367/1, C18000/585 and A11797/1, WP8670

NAA VIC: MP508/1, 255/740/348; MP508/1, 255/742/572 and MP529/3 TRIBUNAL 4/163

NAA NSW: C123, 13681

\section{Secondary Sources}

2nd/3rd Australian Light Anti-Aircraft Regiment Association. 2011. Secretary's Report 1995: The Sentry's Log. Accessed 19 September, 2015. http://www. antiaircraft.org.au/about-us/secretarys-reports/secretarys-report-1995/.

Anderson, B. 2006. Imagined Communities: Reflections on the Origin and Spread of Nationalism. New York: Verso. 
AWM (Australian War Memorial). 2013. The Last Post Ceremony Commemorating the Service of (QX13648) Bombardier Winston Phillip James Ide, 2/10th Field Regiment RAA, Second World War [transcript]. Australian Capital Territory, Australia. Accessed 15 August, 2015. https://www.awm.gov.au/ collection/C1425433/.

.n.d.[a]. Roll of Honour: Winston Phillip James Ide. Accessed 15 August, 2015. https://www.awm.gov.au/people/rolls/R1687787/?query=\&section\%5B 0\%5D=people\&op=Search\&filter\%5Brcdb_id\%5D=528082/.

. n.d.[b]. Australian Prisoners of War: Second World War-Prisoners of the Japanese, Burma-Thailand Railway. Accessed 20 March, 2018. https://www. awm.gov.au/research/guide/pow-ww2-burma-thai/.

Baker, J., Hart, P. and Travers, R. 2017. In "A Chinese Australian Soldier at Gallipoli." Interview by Michael Cathcart [audio, 14:05-18:27]. Books and Arts, RN, 25 April. Accessed 18 August, 2017. http://www.abc.net. au/radionational/programs/booksandarts/a-chinese-australian-soldier-atgallipoli/8442714/.

Beaumont, J., I. Martinuzzi O’Brien and M. Trinca. 2008. Under Suspicion: Citizenship and Internment in Australia During the Second World War. Canberra, Australia: National Museum of Australia Press.

Blackburn, K. 2012. Sportsmen of Changi. Sydney: NewSouth Publishing.

Bryant, R. 1989. "Sergeant Takasuka," Take Post! Newsletter of the 2nd/3rd Australian Light Anti-Aircraft Regiment Association, vol. 6. Accessed 15 August, 2015. https://www.antiaircraft.org.au/take-post/take-post-archive?download $=10$ :take-post-1997/.

Bullard, S. 2006. "Representation of Japanese in Australian Military History and the Effect on Commemoration.' Symposium II: Remembering the Pacific War and Japan-Australia Relations." Ōsutoraria Kenkyu [オーストラリア研 究] 19: 18-23.

Clark, B. and Russell, O. 1945. "Japanese-American Soldiers Make Good," The American Mercury, no. 6 (June), 698-705.

Clyne, J., Smith, R., and Hodges, I. 2015. Chinese Anzacs. Canberra: Department of Veterans' Affairs.

Collins, K. 2012. "Imagining the Golden Race." In Australia's Asia: From Yellow Peril to Asian Century, edited by D. Walker and A. Sobocinska, 99-120. Crawley: UWA Publishing.

Densho. 2017. "Richard Sakakida," Densho Encyclopedia. Accessed 1 October, 2017. http://encyclopedia.densho.org/Richard_Sakakida/.

Eriksen, T. H. 2010. Ethnicity and Nationalism: Anthropological Perspectives. Volume 3. New York and London: Pluto Press. 
Fujita, F. 1993. Foo, A Japanese-American Prisoner of the Rising Sun: The Secret Prison Diary of Frank "Foo" Fujita. Denton: University of North Texas Press.

Growden, G. 2012. "Read It and Weep: Real Heroes Found on the Shelves, Not on the Field," The Sydney Morning Herald, 5 March. Accessed 24 August, 2015. http://newsstore.fairfax.com.au/apps/viewDocument.ac;jsessionid=87B1A5 525D78BB6105C71957BABBC13C?sy=afr\&pb=all_ffx\&dt=selectRange\&dr $=1$ month $\& s o=$ relevance $\& s f=$ text $\& s f=$ headline $\& \mathrm{rc}=10 \& \mathrm{rm}=200 \& \mathrm{sp}=$ brs $\& \mathrm{cl}$ $s=15 \&$ clsPage $=1 \&$ docID $=$ SMH120305JP5CPOI3KB6 $/$.

Haid, P. 2011. Reformulating Citizenship: The Nikkei in Canada and Australia. PhD thesis, School of History and Philosophy, University of New South Wales.

Hasegawa, A. 2014. "Story of Hasegawa Family," Nikkei Australia. Accessed 24 August, 2015. http://www.nikkeiaustralia.com/story-hasegawa-family/.

Hayman, R. 1980. Episodes: A Glimpse of Australia-Japan Relations 1859-1979. Canberra: Union Offset Co.

Hui, J. 2002. "Chinese-Australian Servicemen to be Honoured," The Sydney Morning Herald, 25 April. Accessed 18 August, 2017. https://www.smh.com. au/articles/2002/04/24/1019441262394.html.

Ishii, K. 2008. Caught Between Cultures. Australia: Platypus Graphics.

Ito, R. 1984. We Went to War. Canada: Canada's Wings.

Kaniya, T. [蟹谷 勉]. 1993. Shi ni itaru nōsaido [死に至るノーサイド]. Gushikawa, Japan: Asahi Bungei Bunko [朝日文芸文庫].

Kembrey, M. 2015. “Tony Albert's 'Confronting' Tribute to Indigenous Diggers Unveiled in Sydney's Hyde Park". The Sydney Morning Herald, 31 March. Accessed 18 January, 2018. http://www.smh.com.au/entertainment/artand-design/tony-alberts-confronting-tribute-to-indigenous-diggersunveiled-in-sydneys-hyde-park-20150331-1mbuzo.html.

“Kimi wa nōsaido no fue wo kītaka [君はノーサイドの笛を聞いたか] trailer 3min.” 2009. YouTube video, 3:18, posted by "Roundohmac," 8 September. Accessed 28 August, 2015. https://www.youtube.com/watch?v=9_mrRqVm404/.

Lane, D. 2011. "Hero's 'Enemy' Connections," The Sydney Morning Herald, 24 April. Accessed 24 August, 2015. http://www.smh.com.au/rugby-union/unionnews/heros-enemy-connections-20110423-1ds3s.html.

Lewis, G. 2012. The Growers' Paddy: Land, Water, and Co-Operation in the Australian Rice Industry to the 1990s. Sydney: The University of Sydney Co-Operatives Research Group.

Londey, P. 2015. "Indigenous Australian Servicemen," Australian War Memorial. Accessed 24 August, 2015. https://www.awm.gov.au/encyclopedia/ aborigines/indigenous/. 
Maranzani, B. 2011. "Unlikely World War II Soldiers Awarded Nation's Highest Honor," History Stories. Accessed 10 October, 2017. http://www.history.com/ news/unlikely-world-war-ii-soldiers-awarded-nations-highest-honor/.

Meaney, N. K. 2009. Australia and the World Crisis, 1914-1923. Sydney: Sydney University Press.

Moremon, J. n.d. "Indigenous Australians at War," Department of Veterans' Affairs. Accessed 20 September, 2017. https://www.dva.gov.au/i-am/aboriginalandor-torres-strait-islander/indigenous-australians-war/.

Nagata, Y. 1996. Unwanted Aliens: Japanese Internment in Australia. St Lucia: University of Queensland Press.

. 2001. "Certain Types of Aliens': The Japanese in Australia, 1941-1952." In Relationships: Japan and Australia, 1870s-1950s, edited by P. Jones and V. Mackie, 217-39. Parkville: University of Melbourne, Department of History.

2008. "Naive Patriotism: The Internment of Moshi Inagaki in Australia during the Second World War." In Under Suspicion: Citizenship and Internment in Australia during the Second World War, edited by J. Beaumont, I. Martinuzzi O'Brien and M. Trinca, 112-24. Canberra: National Museum of Australia Press.

Nagata, Y. and Nagatomo, J. 2007. Japanese Queenslanders: A History. St. Lucia: Bookpal for School of Languages and Comparative Cultural Studies, University of Queensland.

NAA (National Archives of Australia). 2017. Australia's Prime Ministers: John Curtin in Office. Accessed 26 April, 2017. http://primeministers.naa.gov.au/ primeministers/curtin/in-office.aspx.

O, Y. 2011. "Cultural Origins of the Kamikaze Special Attack Corps and the 442nd Regimental Combat Team During World War II: A Comparison Between the Japanese Soldiers Raised in Japan and the Nisei Soldiers Raised in America." PhD dissertation, Oklahoma State University. Accessed 26 April, 2017. https://shareok.org/handle/11244/6784/.

Oliver, P. 2002. "Who Is One of Us? (Re)discovering the Inside-Out of Australia's Japanese Immigrant Communities, 1901-1957." Japanese Studies 22 (3): 273-88.

. 2007. "Japanese Relationships in White Australia: The Sydney Experience to 1941." History Australia 4 (1): 5.1-5.20.

. 2008. "Citizens Without Certificates or Enemy Aliens? Japanese Residents Before 1947." In Under Suspicion: Citizenship and Internment in Australia during the Second World War, edited by J. Beaumont, I. Martinuzzi O'Brien and M. Trinca, 125-41. Canberra: National Museum of Australia Press.

Oliver, P. and NAA (National Archives of Australia). 2004. Allies, Enemies and Trading Partners: Records on Australia and the Japanese. Volume 20. Canberra: National Archives of Australia. https://doi.org/10.1080/10371390 22000036968/.

\section{T}

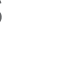


Pearson, C. H. 1893. National Life and Character: A Forecast. London: Macmillan and Co.

Piper, C. 2014. After Darkness. Sydney: Allen \& Unwin.

Queensland Government. 2014. Allied Translator and Interpreter Section (ATIS); Australian 1st Battalion; POW Compound and Interrogation Centre. Accessed 4 August, 2015. http://www.ww2places.qld.gov.au/places/?id=786/.

Rando, G. 2005. "Italo-Australians during the Second World War: Some Perceptions of Internment." Italian Studies in Southern Africa 18 (1): 20-51.

Rowland, M. 2017. "Fall of Singapore Anniversary: How a Military Defeat Changed Australia," ABC News, 14 February. http://abc.net.au/news/2017-02-14/fallof-singapore-75-year-anniversary-commemorated/8267650/.

San Francisco Maritime National Park Association. 2007. USS Pampanito (SS-383): The Third War Patrol. Accessed 22 August, 2015. http://maritime.org/ pamphist/patrol3.htm.

Saunders, K. 1994. "The Dark Shadow of White Australia: Racial Anxieties in Australia in World War II." Ethnic and Racial Studies 17 (2): 325-41. https:// doi.org/10.1080/01419870.1994.9993827/.

Sissons, D. C. S. 1956. Attitudes to Japan and Defence, 1890-1923. Masters thesis, Faculty of Arts, The University of Melbourne.

1980. "A Selector and His Family." Hemisphere 25 (3): 168-74.

. 1986. "Muramats, Jirō (1878-1943)." Australian Dictionary of Biography, National Centre of Biography, Australian National University. Accessed 6 May, 2018.http://adb.anu.edu.au/biography/muramats-jiro-7689/text13459/.

State Library of South Australia. 2017. "T 1917-2016”, Savill Index of The Advertiser Funeral Notices. Accessed 1 November, 2017. http://www.slsa.sa.gov.au/fh/ savill/savill-T.html.

Stead, A. 1904. "Japan and the Policy of a 'White Australia'" The Monthly Review 16: 84-104.

Yazdiha, H. 2010. "Conceptualizing Hybridity: Deconstructing Boundaries through the Hybrid." Formations 1 (1): 31-38.

Yu, O. 2017. “A Chinese Australian Soldier at Gallipoli." Interview by Kate Evans [audio, 18:27]. Books and Arts, RN, 25 April. Accessed 18 August, 2017. http://www.abc.net.au/radionational/programs/booksandarts/a-chineseaustralian-soldier-at-gallipoli/8442714/. 


\section{Governor Takeshi Onaga and the US Bases in Okinawa: The Role of Okinawan Identity in Local Politics}
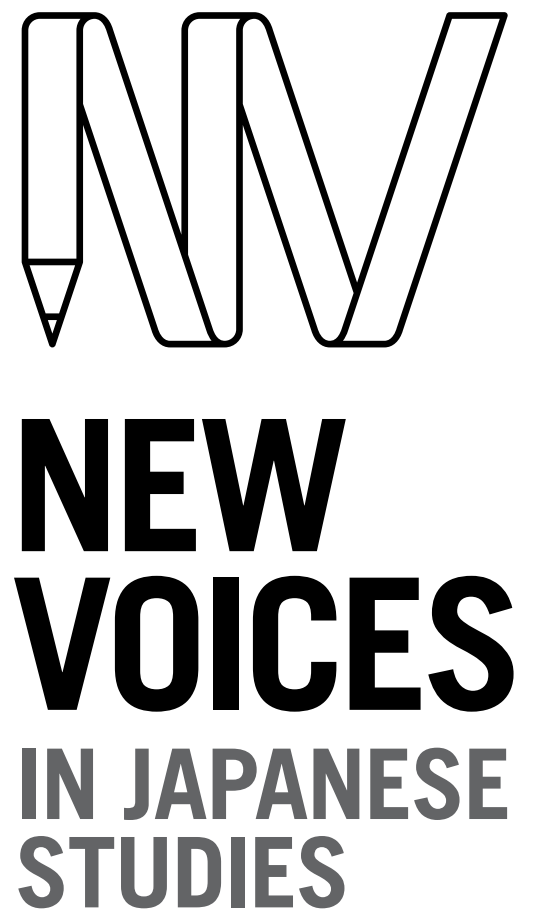

\section{MONICA FLINT}

The University of Sydney

\section{ABSTRACT}

With the increasing importance of the US-Japan Security Alliance amidst heightening regional tensions between Japan and its neighbours, the debate concerning the US base presence in Okinawa has polarised many and garnered significant attention in scholarship and the media. Using a qualitative approach, this article analyses the political rhetoric of Takeshi Onaga, who assumed office as Governor of Okinawa in December 2014. The article finds that Onaga uses an essentialist notion of Okinawan cultural identity and history as a tool for political gain to further an anti-base agenda. It contributes a new perspective to the literature on US bases in Okinawa by shedding light on the convergence of representations of contemporary Okinawan identity, ethnicity and history in the local Okinawan political debate. Further, in drawing on examples from Onaga's Twitter and YouTube accounts, the article responds to the scarcity of literature on the relationship between social media and politics in Japan.

\section{KEYWORDS}

contemporary; social and cultural identity; Futenma; ideology; international relations; narrative; occupation; Okinawa; Pacific War; political communication; politics; representation; social media; state; Takeshi Onaga; US bases

\section{JAPANEOUNDATION \& BRINGING JAPAN TO YOU \\ To link to this article: https://doi.org/10.21159/nvjs.10.02}

\section{ISSN 2205-3166}

New Voices in Japanese Studies is an interdisciplinary, peer-reviewed journal showcasing the work of emerging scholars from Australia and New Zealand with research interests in Japan.

All articles can be downloaded free at newvoices.org.au

(c) The Japan Foundation, Sydney and Monica Flint, 2018

\section{(c) $(1)$}

This work is licensed under a Creative Commons Attribution-NonCommercialNoDerivatives 4.0 International License. 


\section{INTRODUCTION}

Okinawa Prefecture, a small island chain southwest of Kyushu in Japan, is renowned for its distinct history, culture and geography. ${ }^{1}$ Formerly an independent state known as the Ryukyu Kingdom, Okinawa's history and its relationship with mainland Japan over the past 500 years has been tumultuous. Defining events include the Satsuma Invasion in 1609, annexation to mainland Japan in 1879, the Battle of Okinawa in 1945 and the establishment of a permanent US military presence from $1945 .^{2}$ Against this background, and with growing contention around the US base presence in recent decades, the construction of a master historical narrative and notion of a collective 'Okinawan' identity vis-à-vis the mainland has become increasingly salient in local politics. With an estimated population of 1.4 million (Okinawa Prefectural Government 2018), Okinawa currently hosts 47,300 Americansincluding military personnel, affiliates and their families-on 32 bases (see map, Figure 2). The land area of these bases accounts for $73.7 \%$ of all US base land area in Japan (Okinawa Prefectural Government 2016). The base controversy centres around Okinawa's disproportionate responsibility (imposed by the central Japanese government) for hosting US military bases. The bases have been associated with increased air and noise pollution, crime and a lack of prefectural autonomy, which intersect with a number of other significant issues such as economic development, regional security concerns, environmentalism and pacifism (Cooley and Marten 2006; Chanlett-Avery and Rinehart 2014; Hook et al. 2015). The base issue has ignited debate among scholars and activists regarding Okinawa's alleged position as an internal 'colony' of Japan that has suffered from continued exploitation and oppression since its annexation (Arakawa 2013; Arasaki 2001; McCormack 2007; McCormack and Norimatsu 2012). The most notable similarity amongst anti-base politicians, activists and scholars-despite their vastly different motivations, interests and goals-is the attempt to define what it means to be Okinawan and to use this constructed identity as a persuasive and at times emotive argument against the US military presence.

This article will examine how notions of contemporary Okinawan identity have become integral to anti-base discourse, and explore the implications of this in local politics. In doing so, the analysis will challenge assumptions of Okinawan identity as unitary or fixed; it will shed light on the pliable nature of collective identity and the internal diversity and fissures present within Okinawa. Specifically, the article focuses on the use of Okinawan identity in the political rhetoric of Governor Takeshi Onaga [翁長 雄志; b. 1950] during his election campaign of October-November 2014 and his time in office from December 2014 to the present. Okinawa's 2014 gubernatorial election centred upon the contentious plan to relocate the Marine Corps Air Station (MCAS) in Futenma ('the Futenma base'), currently within the densely populated city of Ginowan,

\footnotetext{
1 At present, Okinawa Prefecture is comprised of the central Okinawa Islands and southern Sakishima Islands, whilst the neighbouring Amami Islands belong to Kagoshima Prefecture (see map, Figure 1). All three island groups belonged to the indigenous Ryukyu Kingdom until 1609, when Amami was ceded to the Satsuma clan after the Satsuma Invasion. Throughout this article, 'Okinawa' is used to refer to Okinawa Prefecture. 
to the small coastal town of Henoko. ${ }^{3}$ Onaga campaigned as an independent conservative candidate on a fervent anti-base platform, committed to blocking base construction at Henoko. He was previously a member of the Liberal Democratic Party (LDP) and served as Mayor of Naha, Okinawa's capital city, from 2000 to 2014. In the 2014 election, Onaga achieved a clear victory over his three rival candidates, winning $51.6 \%$ of votes. ${ }^{4}$ As governor, Onaga has used various political and legal means to block the construction of the Henoko base.

This article analyses Onaga's public speeches, press conferences and social media posts to shed light on the central role of a constructed 'authentic' Okinawan identity in his anti-base rhetoric. By drawing upon existing insights into the fluid and political nature of identity in the specific sociocultural and historical context of Okinawa, the article will reject reductionist views that characterise Onaga's election victory as a manifestation of unanimous antibase sentiment amongst a unified Okinawan people. The analysis builds upon a rich body of literature that explores history as a powerful resource in identity and community formation to show how representations of group identity and historical legacies in Okinawa have been used by Onaga to secure the antibase vote (Anderson 2006; Reicher and Hopkins 2001; Liu and Hilton 2005).

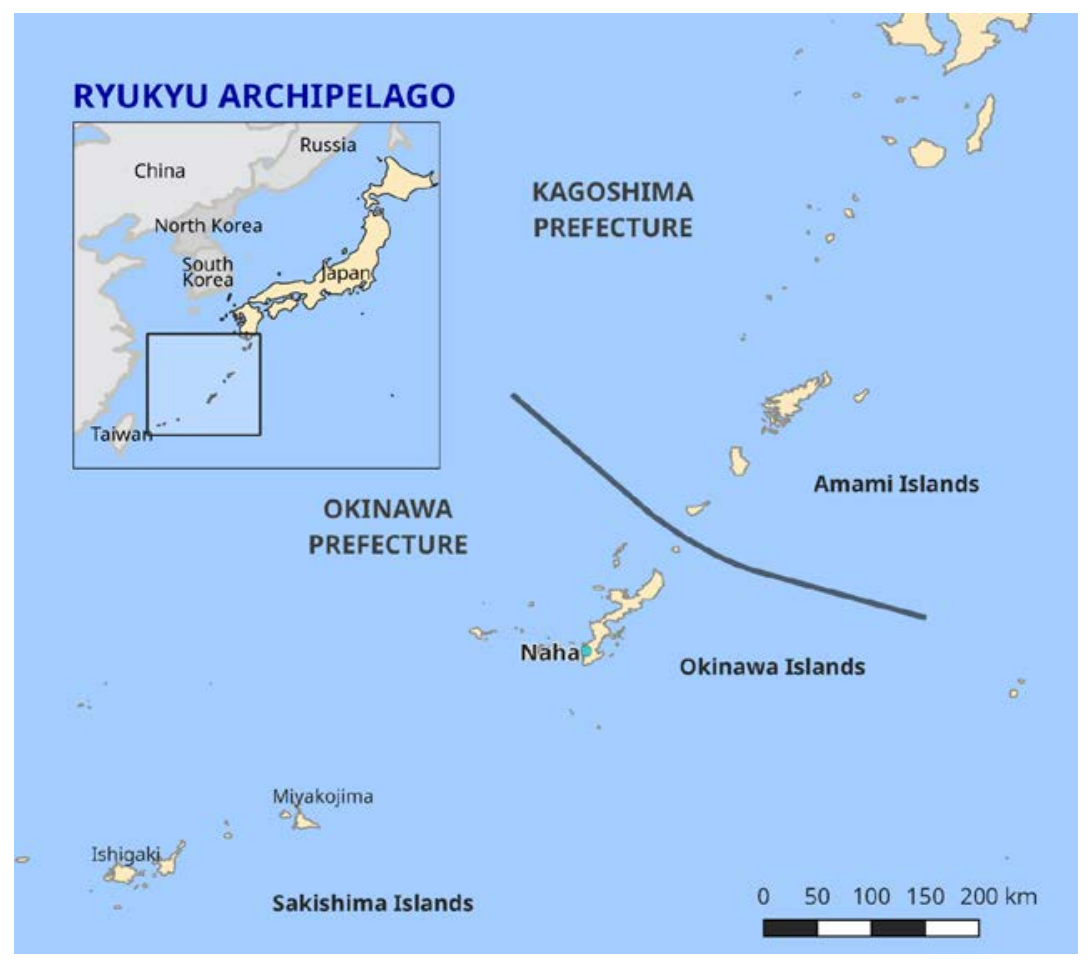

Figure 1: Map of the Ryukyu Archipelago

Source: https://www.naturalearthdata.com

3 In 1996, the Japanese and US governments agreed to close the US base in Futenma upon completion of offshore replacement facilities on the coast of Henoko (a less populated area on Okinawa Main Island), due to safety concerns for nearby Ginowan residents. However, the closure has not been executed as the central Japanese and Okinawan prefectural governments are yet to reach an agreement regarding the location of the replacement base. The preceding Okinawan governor, Hirokazu Nakaima, initially rejected plans to construct the new base at Henoko. However, in December 2013, Nakaima conceded that Tokyo's solution was the most pragmatic and approved construction to start at Henoko. In October 2015, newly elected Governor Onaga revoked Nakaima's approval, thereby suspending construction of the Henoko base. This led to a series of court battles, culminating in December 2016 when the Supreme Court ruled in favour of the national government and declared Onaga's action illegal. Construction at Henoko recommenced soon after (Shimada 2016). 


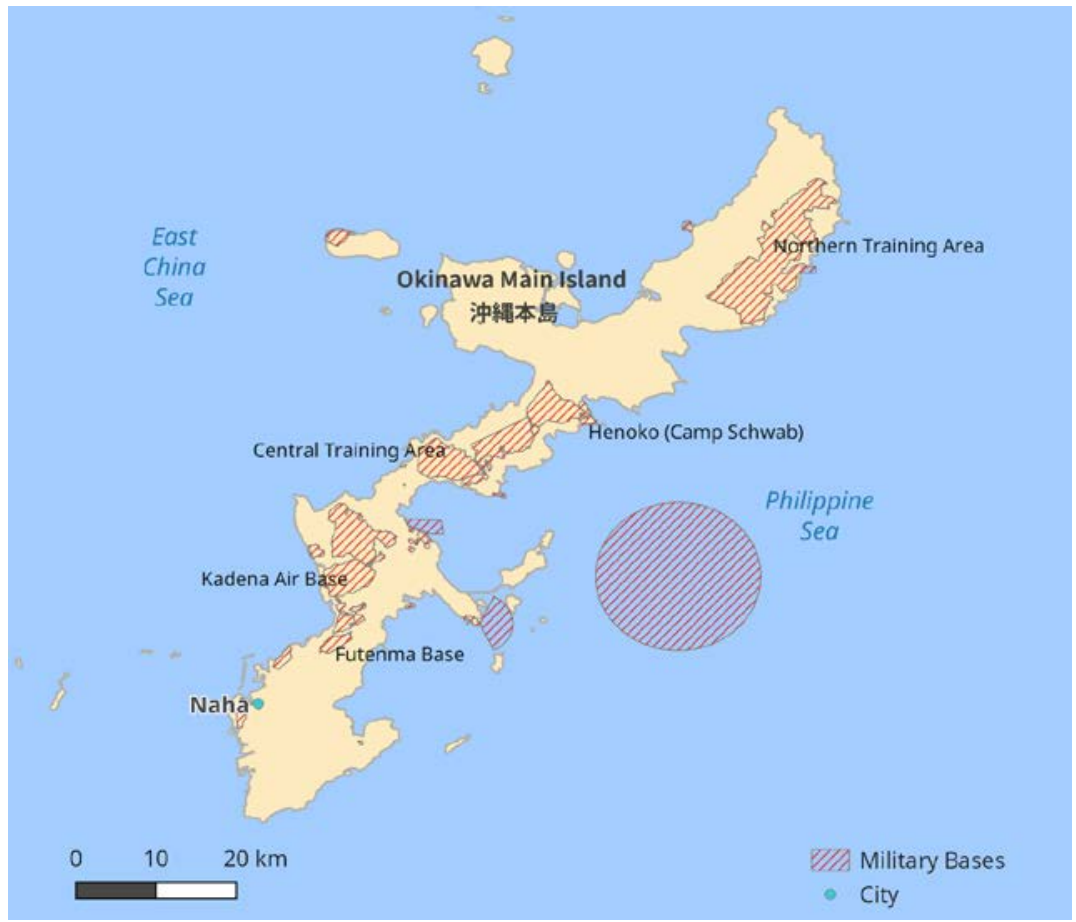

Figure 2: Map of US Military Facilities on Okinawa Main Island

Source: OpenStreetMap (https://www.openstreetmap.org). (C) OpenStreetMap contributors. Licensed under Creative Commons Attribution-ShareAlike 2.0 (CC BY-SA 2.0)

\section{OKINAWAN HISTORY AND IDENTITY}

Okinawa's history has largely been shaped by the competing political and strategic agendas of significant stakeholders in the region. As a result, the constant flux in Okinawa's geopolitical relationships has informed the complex and multifaceted nature of Okinawan identity today. Close trading ties with neighbouring countries, including the tributary relationship with China established in the fourteenth century, have imbued Okinawan traditions, architecture and cuisine with hybrid elements from diverse cultures. In the more recent past, the foreign policy objectives of Japan and the US have been the driving forces behind the key turning points in contemporary Okinawan history, beginning with the chain of events that led to Japan's annexation of Okinawa in 1879 in the context of Japan's expansionist agenda. Since Japan's defeat in World War II, the US's approach to Okinawa has been informed by the foreign policy objective of consolidating a US-centred regional order and cultivating strong allies in the Western bloc. The US-Japan Security Treaty, concluded during the US occupation of Japan, legitimated the stationing of US military bases in Okinawa, and remains of particular relevance today as geopolitical tensions in the region (such as North Korea's nuclear and ballistic missile testing) increase. ${ }^{5}$

In addition to cultural legacies from the former Ryukyu Kingdom, Okinawa's interactions with key actors in the twentieth century have had complex implications for its historical narrative and shared notions of Okinawan identity. A common narrative of Okinawan history describes its demise from former glory as a flourishing trading hub during the era of the Ryukyu 
Kingdom, its subjection to Japanese colonialism after the Satsuma Invasion and its eventual annexation to Japan (Siddle 1998, 117). However, a coherent idea of what being 'Ryukyuan' means and how it may differ to being 'Japanese' did not develop until long after the Ryukyu Kingdom had been deposed (Siddle 1998, 119), and has changed over time ever since. At the beginning of the fifteenth century, Shō Hashi [尚 巴志; 1372-1439] unified Okinawa Main Island, which had previously been divided into three separate kingdoms (Takara 1980, 43). The monarchical regime exerted influence across the entire Ryukyu archipelago, establishing the Ryukyu Kingdom. During this era, Ryukyuan vernaculars across the archipelago were diverse and often mutually unintelligible due to geographical diffusion (Heinrich et al. $2015,1) .{ }^{6}$ It is therefore unconvincing that there existed a strong consciousness of a united Ryukyuan identity at that time, despite its frequent idealisation in contemporary political rhetoric, as will be discussed later in this article. Okinawan cultural identity is a fluid construction that is not founded in inherent truths; its contemporary characterisations must therefore be examined within the context of Okinawans' ongoing political struggle since the process of the Ryukyu Kingdom's annexation into Japan.

Shortly after the Meiji Restoration in 1868, the Meiji government moved towards fully incorporating the Ryukyu Kingdom into Japan. In 1874, it sent an expedition to Taiwan as a punitive measure after shipwrecked Ryukyuans were massacred by Taiwanese aboriginal groups in southern Taiwan. This act demonstrates an affirmation of Japanese sovereignty over the islands (Mizuno 2009 , 683). In 1875, the government prohibited the tributary relationship between Ryukyu and Qing-dynasty China, and in 1879, the Ryukyu Islands were formally annexed and became Okinawa Prefecture. The Meiji government promoted language standardisation and new education reforms that emphasised Japanese nationalism, amongst other assimilation measures (Tanji 2006, 26). Initially, the Ryukyu ruling elite resisted the incorporation into Japan and maintained pro-China sentiment until Japan's 1895 victory in the Sino-Japanese war (Siddle 1998, 120-21). Subsequently, in addition to pressure from the central government to assume a 'Japanese' identity, there emerged a will from Okinawans-particularly the elite-to assimilate and be associated with the powerful, modernised nation-state of Japan for their own economic advantage (Tanji 2006, 27). Some scholars have interpreted this active will to assimilate as the internalisation of colonialism, whereby the Okinawan public wanted to be treated as equals in Japanese society, necessitating the denial of their own customs and language which were perceived by some as inferior and backwards (Clarke 2015, 622-23).

The next major turning point in the history of Okinawan identity politics came in the aftermath of the Battle of Okinawa. The US had strategised to retain the islands in the Ryukyu archipelago as separate from Japan for military use. ${ }^{7}$ In order to provide a rationale for this separation and to lessen objections from 
Japan, US officials classified the inhabitants of the archipelago as 'Ryukyuans' (rather than 'Okinawans'), and therefore as non-Japanese (Siddle 2003, 134). In a process described as "De-Japanization" and "Ryūkyūanization", the US military authorities aimed to construct an independent Ryukyuan identity by emphasising its cultural and ethnic uniqueness and repatriating Okinawans in mainland Japan back to Okinawa (Augustine 2015, 217-18). However, the "Ryūkyūanization" policy ultimately backfired when its tacit implications of decolonisation and liberation were not realised under direct US military rule, fuelling a movement (known as 'the reversion movement') which called for the US military to withdraw from Okinawa, and for Okinawa's return to Japan (Augustine 2015, 222). ${ }^{8}$ Furthermore, as this article will demonstrate, this idealisation of a unique Ryukyuan identity that was promoted by US officials in the post-war era is now being used against the US in contemporary Okinawan politics.

The reversion movement gained traction in the late 1950s and 1960s, following the end of the US occupation of mainland Japan in 1952. Many Okinawan proponents of the reversion movement promoted their identities as being Japanese rather than Ryukyuan, underlining the need for "ethnic unity" to the "ancestral land" of Japan (Siddle 2003, 136). However, the desire to return to mainland Japan did not necessarily indicate a denial or rejection of an Okinawan identity altogether. Rather, it should be understood within the context of frustration at the increasing gap between Okinawa and the mainland, as Japan was enjoying high economic growth and democratic freedoms at the time (Siddle 2003, 136). Okinawa was returned to Japan in 1972 under the Okinawan Reversion Agreement, and the way in which Okinawans define their relationship with the mainland remains integral to how they conceptualise their collective identity today. ${ }^{9}$

More recent characterisations of Okinawan identity describe a unified people who are fighting back against centuries of suffering, oppression and exploitation (Nakano and Arasaki 1976; Arakawa 2013; McCormack and Norimatsu 2012). Tanji (2006) argues that it is the "myth" of Okinawan "struggle" that unites the otherwise diverse and fractured "community of protest" within Okinawa (8). The "myth" is defined as a story or narrative that resonates widely by drawing upon a "large reservoir of memory" to legitimise a sense of collective identity and collective action (Tanji 2006, 7-8). The pliability and accessibility of such a myth, which draws upon key historical events including the Battle of Okinawa, US military rule and the infamous 1995 gang-rape of an Okinawan girl, allows for diverse groups to identify with this collective identity, creating a façade of unity and homogeneity (Tanji 2006). ${ }^{10}$ This research will build upon this conceptualisation of the identity "myth" through the case study of Takeshi Onaga by examining how contemporary notions of Okinawan identity are constructed and how this plays out in local politics.

\footnotetext{
8 The Amami Islands were returned to Japan in December 1953; however, Okinawa Prefecture (Okinawa and Sakishima Islands) was not returned until 1972.

9 The Okinawa Reversion Agreement [沖縄返還協定] is an agreement between Japan and the US in which the US returned control of Okinawa Prefecture to Japan.

10 In 1995, a twelve-year-old Okinawan girl was abducted and raped by three US military service members. The incident took place near Camp Hansen on Okinawa Main Island, where the three US military service members were stationed. The crime was widely publicised in Okinawan and mainland Japanese media, and sparked public outrage and debate on the continued presence of US forces in Okinawa. As a result, the US and Japanese governments established the Special Action Committee on Okinawa (SACO) [沖縄に関する特別行動委員会] in November 1995 to examine ways to reduce the base burden on Okinawan people (Chanlett-Avery and Rinehart 2014, 7).
} 
This section will look more closely at Onaga's campaign rhetoric to explain how and why his election campaign was successful. Takeshi Onaga campaigned as an independent anti-base candidate, despite having been a core member of the LDP and campaign manager for the LDP-backed incumbent Hirokazu Nakaima in the previous gubernatorial election [2010]. Onaga's election campaign centred on his policies to significantly reduce the number of US bases on Okinawa Main Island and his commitment to suspend the Henoko base construction. He won the election with 100,000 more votes than the incumbent governor Nakaima (Ryūkyū Shimpō 2014). The $14.7 \%$ swing against Nakaima (Okinawa Election Administration Committee 2015, 27) can be seen as indicative of strong voter backlash against his approval of the landfill project at Henoko-against his 2010 election pledge-so that base construction could commence. Many media reports and scholars, including prominent Okinawan Studies scholar Gavan McCormack, seemed to position the election win as a demonstration of the overwhelming anti-base sentiment in Okinawa:

A week in Okinawa during November 2014...left this author with an overwhelming impression of...the determined, non-violent, democratic resistance of the Okinawan people [...]. The contradiction was never so manifest as in the outcome of the 16 November election, in which the Okinawan people delivered a massive majority to the anti-base construction candidate for Governor, Onaga Takeshi, thereby declaring in effect that Okinawa would not allow construction to go ahead on the new base for the US Marine Corps on Oura Bay.

(McCormack 2014)

However, as the following analysis will show, rather than solely reflecting the electorate's antipathy towards US military presence, the election presented insights into the power of nuanced campaign messaging, crafted to leverage the aspects of Okinawan identity with the broadest potential resonance across Okinawa's diverse population.

Arguably, one element behind the success of Onaga's campaign was his use of Twitter, which was ground-breaking at the time in the context of Japanese politics. ${ }^{11}$ In 2016, Twitter reported that there were over 40 million active Twitter users in Japan (Twitter Japan 2016), making it Japan's most popular social media platform. In spite of this, the use of online platforms for political communication has lagged considerably behind its prolific use in other nations. This is likely to be a result of strict election regulations. Enacted in 1950, the Public Offices Election Law (公職選挙法) regulates electoral campaigning by controlling spending and media access with the aim to eliminate unfair advantages between candidates. It was not until April 2013 that the Japanese Diet passed revisions to the law to specifically allow candidates to use the internet as a campaign tool (Ministry of Internal Affairs and Communication 2013). The revisions came amidst growing global trends to leverage the

11 The 140-character limit on Twitter allows for quite substantial messages in Japanese, particularly with the use of kanji character compounds (it was for this reason that Japanese, along with Chinese and Korean, was exempt from Twitter's 2017 character-limit increase). For further information, see https://blog.twitter.com/official/ en_us/topics/product/2017/Giving-you-more-characters-to-express-yourself.html. 
accessibility and interactivity of digital platforms for political use (for example, digital platforms allegedly played a central role in Barack Obama's successful presidential campaigns in 2008 and 2012). Japanese lawmakers anticipated that the revisions would invigorate political discussion amongst citizens, and ultimately increase political participation and voter turnout (Mie 2013). ${ }^{12}$

In this context, Onaga's use of social media in his 2014 campaign was innovative, and in drawing on examples from Onaga's Twitter and YouTube accounts, this article responds to the scarcity of literature on the relationship between social media and politics in Japan. Onaga's rhetoric leverages Okinawans' preexisting affinities and sense of belonging to a wider Okinawan community to build collective agreement in alignment with his political objectives. Throughout his campaign, Onaga consistently framed the election not as a choice between different policies and politicians, but as an opportunity to send a powerful message to the central Japanese government: that one's identity as an Okinawan trumps any other political allegiance. Onaga's use of slogans such as “All Okinawa” (オール沖縄), “Identity over ideology” (イデオロ ギーよりアイデンティティー) and “Okinawans together as one” (県民の心を一つ に) operated throughout his campaign to appeal to prefectural citizens' sense of ethnic attachment. For example, in one YouTube video, Onaga states:

I will resolve Okinawa's base problem by rallying the power of the 'All Okinawa' identity over ideology. I will bring together the heart of Okinawans as one and overcome the political left/right binary. ${ }^{13}$

(Onaga 2014b)

On both a semantic and symbolic level, the slogans reinforce a sense of oneness and the importance of Okinawans coming together to successfully challenge the central Japanese government. Further, they also function powerfully in the digital media landscape: as Noakes and Johnston have demonstrated, slogans and symbols are effective mechanisms to "crystallize the essential components of a frame in an easily recalled clip", to ensure that a message can be spread quickly and efficiently $(2005,8)$. Onaga's emphasis on collective action and unity in this example is characteristic of his entire campaign strategy, deploying Okinawa's cultural identity as the unifying principle that transcends all other allegiances.

Onaga's campaign also demonstrates an attention to detail around language choice that aligns with the central trope of Okinawan unity. Onaga judiciously chooses the word 'kenmin' (県民; lit., 'people of the prefecture') as an inclusive definition of who is Okinawan, as seen in "Okinawans together as one” (県民の心をつに). In the Okinawan context, 'kenmin' is a “term of self-demarcation" that closely embodies a sense of Okinawan nationalism, whilst still acknowledging a sense of belonging to mainland Japan (Tanji and Broudy 2017, 179). The use of 'kenmin' connotes a sense of a cohesive community amongst the diverse island groups across the prefecture. It is significant that Onaga uses the term 'kenmin' and not 'uchinānchu' (also 
meaning 'Okinawans'), which is a term commonly used by Okinawans to distinguish themselves from mainland Japanese and convey a sense of pride in Okinawan culture, ethnicity and historical legacies (Siddle 2003, 133). The word 'uchinānchu' derives from 'Uchinä', the name for Okinawa Main Island in local dialect; thus, 'uchinānchu' only refers to inhabitants of the main island. In choosing the word 'kenmin' over 'uchinānchu', Onaga includes all island groups into the scope of his overarching "All Okinawa" identity.

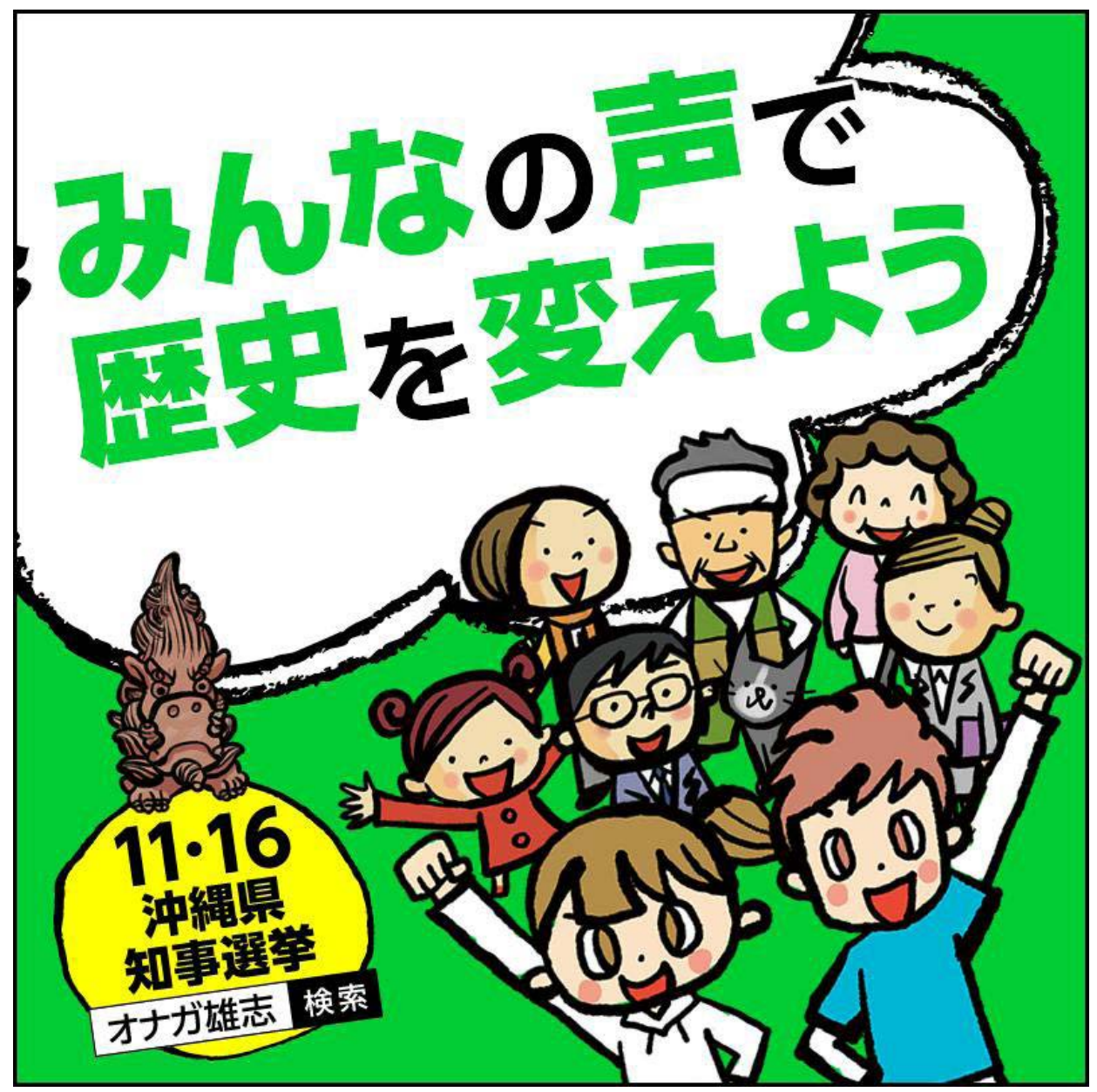

Figure 3: The image accompanying a tweet on Onaga's official Twitter page, captioned: “With everyone's voice, let’s change history” (みんなの声で歴史を変えよう). Source: Twitter post by “onagatakeshi102", 9 November, 2014, 3:18pm. https://twitter. com/onagatakeshi102/status/531314798504329216/. Artist unknown. Reproduced in accordance with Section 41 (fair dealing), Australian Copyright Act 1968.

Eye-catching visuals in conjunction with slogans, as exemplified in Figures 3 and 4 from Onaga's Twitter page, help to further amplify Onaga's message of an inclusive community of 'us Okinawans', whose collective voices have the power to sway the central government. The animal resembling a lion in both images is a depiction of a shiis $\bar{a}$, an imaginary beast from Ryukyuan mythology that is said to ward off evil spirits. It is a significant indigenous totem that symbolises the convergence of tradition, group identity and cultural continuity (Hunter 2012, 83). Statues of shiisa are commonly seen today at the entrances and gates of homes and buildings across Okinawa. As the shiis $\bar{a}$ originated from China before being adopted by the former Ryukyu Kingdom in the 13th to 14th century (Okinawa Prefectural Government 2015), the totem has become a salient symbol of Okinawa's hybrid culture that is distinct from mainland Japan. A small shiisā statue is the quintessential Okinawan souvenir 
for mainland Japanese tourists as it is seen to symbolise Okinawan culture (Hunter 2012, 83). The shiisā's enduring presence and ubiquitous nature in everyday life show how contemporary Okinawan identity remains deeply rooted in its ancient Ryukyuan past. By tapping into cultural symbols, Onaga appeals to Okinawans' sense of pride in their rich history and its legacies, thereby reinforcing his message of "identity over ideology".

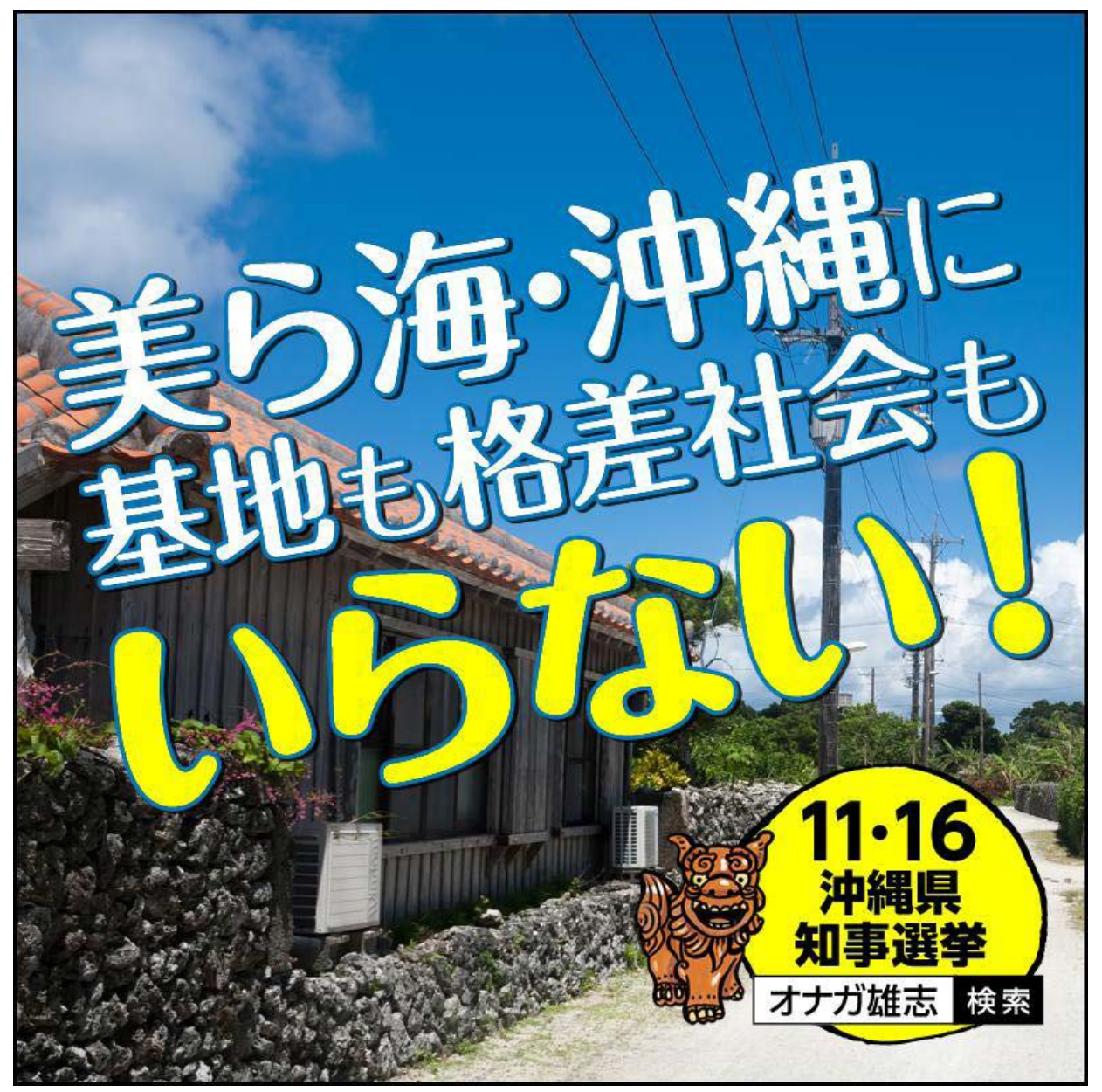

Figure 4: An image from another of Onaga's tweets, captioned with use of Okinawan vocabulary: "We don't need bases and inequality in Okinawa and our beautiful oceans!" (美ら海・沖縄に基地も格差社会もいらない!).

Source: Twitter post by “onagatakeshi102”, 9 November, 2014, 3:18pm. https://twitter. com/onagatakeshi102/status/531314946143825920/. Artist unknown. Reproduced in accordance with Section 41 (fair dealing), Australian Copyright Act 1968.

\section{ONAGA IN OFFICE}

Since taking office in December 2014, Onaga has actively sought media opportunities to mobilise support within Okinawa and bring his anti-base agenda before the central Japanese government. Onaga draws upon history as a symbolic resource to redefine what it means to be Okinawan and connects this with his political objectives to gain followers. In office, as with his campaign, Onaga continues to emphasise collective identity, successfully attracting public support by tapping into two emotionally sensitive aspects of Okinawan consciousness: (1) a shared ancestry and history, and (2) the collective memory of war and hardship. 
The previous section illustrated how Onaga successfully framed the election as a choice of local identity over political ideology, a message which he has continued to foreground throughout his time in office to date. Since assuming office, Onaga has often drawn upon allusions to shared ancestry and the legacy of the ancient Ryukyu Kingdom. For example, in his 2014 inauguration address, Onaga outlined his policy visions, emphasising the importance of recognising and drawing inspiration from Okinawa's ancient history in order to build a prosperous future:

As outlined in the Okinawa $21^{\text {st }}$ Century Vision plan, which was created with the collective wisdom of Okinawan residents, I will leverage the soft power inherited by our uyafäfuji [ancestors], and...open up Okinawa to create a place where umanchu [all Okinawans] can smile. ${ }^{14}$

(Onaga 2014a)

The strategic use of Okinawan vocabulary ('uyafäfuji', discussed below, and 'umanchu', meaning 'everyone' or 'all [Okinawans]') in preference to standard Japanese encourages a sense of familiarity and togetherness by highlighting a shared origin with other Okinawans and denies access to those outside of the Okinawan cultural sphere. In particular, the culturally significant Okinawan word 'uyafäfuji', meaning 'ancestors', alludes to the central tradition of ancestor veneration in the indigenous Ryukyu religion (琉球神道) and increases the speech's resonance by reaching into the depths of the Okinawan cultural consciousness.

In the contemporary context, Onaga's use of local vocabulary in highly publicised official speeches may also be seen as an act of resistance and revival in response to historical efforts to impose standard Japanese upon the prefecture. The Meiji government's measures to standardise language in Okinawa were implemented in the early $20^{\text {th }}$ century, following Okinawa's annexation. These measures included penalising children at school for speaking in local dialects, with punishments including reduction of grades or being made to wear a wooden "dialect tag" (方言札) around their necks (Anderson 2009, 31-34). In addition to employing Okinawan lexicon, at times Onaga also speaks entire paragraphs in Shuri dialect. ${ }^{15}$ For example, in a speech at a prefectural citizens' assembly, he begins his address thus:

Hello everyone. My name is Onaga Takeshi, the Governor of Okinawa Prefecture. I am pleased to be here today. Thank you everyone for gathering here to stop the new Henoko base...I think there are over 30,000, maybe 4050,000 Okinawans here. Thank you to so many that have gathered here today despite the heat. Let's do our best. ${ }^{16}$

(Onaga 2015e; underline added to indicate use of Okinawan vocabulary) 
By deploying the notion of common ancestry and kinship for political means, Onaga appears to insinuate that being a 'genuine' Okinawan inherently necessitates an anti-base point of view.

The important role of kinship in constructing an oppositional consciousness against the Henoko base has been identified in previous studies. Inoue's (2007) anthropological research represents the most comprehensive study into the relationship between identity construction and attitudes towards US bases. Specifically, Inoue elucidates the internal diversity and emerging societal fissures in the town of Henoko, revealing an explicit demarcation between "genuine" Henoko residents and the so-called "out-of-towners" (2007, 142). According to the study, "genuine" Henoko residents were those with extended familial lineage from the area, sometimes tracing back to the Ryukyu Kingdom, whilst "out-of-towners" were residents who immigrated to Henoko later, particularly after the war. It was perceived that the new "outof-towner" Henoko residents "wanted the offshore base because they did not share Okinawa's collective memories of war, the bases, and the servicemen, while genuine natives did share those memories and, consequently, did not and should not want the new base" (Inoue 2007, 142-43). Inoue (2007) concludes that this "genuine, righteous" anti-base identity of the native Henoko residents was being constructed as the authentic Okinawan perspective that was combatting the "immoral" and "corrupt" power of Tokyo and Washington (143). I argue that Onaga similarly uses the notion of ethnicity and the historical differences between Okinawa and mainland Japan to frame the US base dispute as a conflict between the inherently peaceful island of Okinawa and an overbearing central government.

Furthermore, Onaga often juxtaposes positive images of the historical Ryukyu Kingdom as a peaceful trading hub with the tragic events that have occurred since its annexation to Japan, thereby implying that the Japanese government's policies have led to Okinawa's economic stagnation. ${ }^{17}$ Okinawa remains Japan's poorest prefecture, as it did not share the post-war high economic growth period with the mainland and it relies on economic stimulus measures from Tokyo (Cooley and Marten 2006). In one press conference, Onaga begins his speech by describing the former Ryukyu Kingdom's flourishing culture and economy, asserting that the Ryukyuans were the centre of naval trade between China, Japan and Southeast Asia for many centuries, until the islands became part of the greater Japanese territory and their prosperity was systematically taken away (Onaga 2015d). He similarly echoes this message in another speech, following the lawsuit filed by the central government against Okinawa Prefecture regarding Onaga's cancellation of landfill permission at Henoko:

For a period of about 500 years, Okinawa was the Ryukyu Kingdom. We enjoyed a great period of trade that encompassed Japan, China, Korea and Southeast Asia. Ryukyu was annexed to Japan in 1879, 136 years ago. Ryukyu strongly resisted [the annexation], so the Japanese government employed

17 For example, the Battle of Okinawa is widely accepted as one of the bloodiest battles of the Pacific War, with a considerable number of civilian casualties (see footnote 7). The 1972 reversion of Okinawa to Japan after the US occupation has also been seen by some as a deception: while Japan regained administrative control, much of Okinawa's land was not returned to locals, but rather allocated for the construction of US military bases (McCormack and Norimatsu 2012). Onaga also foregrounds incidents of crime, such as the 1995 rape incident, 
armed forces under the label 'Ryūkyū shobun' [処分; 'disposal']. What awaited after the annexation was World War II, 70 years ago. Japan's only ghastly ground warfare took place [in Okinawa], incurring both military and civilian casualties. Two hundred thousand people, including approximately 100,000 Okinawan civilians, were sacrificed. ${ }^{18}$

(Onaga 2015c)

The phrase 'Ryūkyū shobun' (琉球処分) is often translated as the 'disposal of Ryukyu', and originally referred to the process of Japan establishing Okinawa Prefecture in 1879 by formally annexing the Ryukyu domain. However, many Okinawans refer to a number of events in Okinawan history as acts of shobun, including the Satsuma invasion, the US occupation and the 1972 reversion to Japan, thus connecting a series of tragic and oppressive events enforced by the powers of Japan and the US (McCormack 2007, 155).

Moreover, in the conclusion of his speech, Onaga again stresses the 'true' cultural essence of Okinawa as being the legacy of the once-thriving Ryukyu Kingdom. He asserts:

The future of Okinawa should exhibit the spirit of bankoku shinryō and become the bridge between Japan and Asia, and someday become a neutral zone of peace for the Asia-Pacific region. That is my wish. ${ }^{19}$

(Onaga 2015c)

Bankoku shinryō (万国津梁; 'bridge between nations'), is an Okinawan expression alluding to a famous bronze bell that was cast in 1458 and hung in the main hall of Shuri Castle in Naha. The bell is known as the Bridge of Nations Bell due to its inscription describing Ryukyu Kingdom's prominence in maritime trade between East and Southeast Asia (Ota 1996, 40), and it has come to symbolise the former prosperity of Ryukyu as a dynamic and hybrid trading hub. In a sense, the governor's frequent allusions to Okinawa's past as inspiration can be perceived as reclaiming the notion of being 'uncivilised' - a notion embedded in the Meiji Government's assimilation policies towards Okinawa soon after its annexation-and redefining it as meaning "not yet corrupted by power and militarisation" (Siddle 1998, 127).

\section{Collective Memory of War and Hardship}

Both during his electoral campaign and later as Governor, Onaga has also effectively used evocative imagery of and allusions to the experiences of war and suffering to capitalise on the powerful memories of the Battle of Okinawa that are embedded into the social fabric of the Okinawan community. For example, in one speech, Onaga emphasises the historic vulnerability of Okinawan citizens to US military forces by evoking images of weaponry and powerful machinery: 
After the war, Futenma Air Station and other bases were seized while Okinawan citizens were being housed in refugee camps. Then, residential land was forcibly taken with bayonets and bulldozers, and bases were constructed. ${ }^{20}$ (Onaga 2015e)

The image of the peaceful everyday life of innocent citizens juxtaposed with the forceful seizure of Okinawan land and usurpation by the US military portrays Okinawans' sense of displacement and loss in the face of an overwhelming and domineering power. In another example, Onaga criticises the government for exploiting Okinawa purely "as a territory" (Onaga 2015f), and contrasts mainland Japan's economic success with Okinawa's struggles:

For 27 years, from the time under US military administration to the reversion, we Okinawans were not Japanese citizens, nor American citizens. Yet, Okinawan bases were used for wars like Vietnam [...]. I think that, while Japan had peace and high economic growth after the war, Okinawa, for 27 years, was made to be used freely by the US military. ${ }^{21}$

(Onaga 2015f)

The persuasiveness of Onaga's use of wartime and postwar imagery is reinforced by his ability to seamlessly connect historical events with today's Henoko base dispute to position Okinawa as shouldering a prolonged burden in the form of the US military presence. For example, in a press conference on the lawsuit filed by the central Japanese government against Okinawa for revoking approval for Henoko construction, Onaga argues:

[The base construction at Henoko] appears to be just like the bayonets and bulldozers from the war. Okinawa's lack of right to self-determination is no different from 70 years ago, except that this time it is not the US military, but the Japanese government that is using the law as its shield. ${ }^{22}$

(Onaga 2015b)

Linking past and present, Onaga insinuates that the new base construction at Henoko is yet another instance of the central government subjugating the Okinawan people to its will by actively dismissing their opposition and using any means possible to ensure that the Henoko plan goes ahead. Onaga also positions the anti-base movement as a natural response by Okinawans to the collective cultural memory of wartime atrocities. For example, in an address on Okinawa Memorial Day, the governor states:

[The reason why Okinawans can never forget the grief caused by the Battle of Okinawa] is because we Okinawans remember clearly the tragedy brought on by war, with our eyes, ears and skin; from our hearts, we wish for peace for the people who were made victims of war, and we hope for eternal peace. ${ }^{23}$

(Onaga 2015a)

20 「普天間飛行場もそれ以外の基地も戦後、県民が収容所に収容されている間に接収をされ、また、居住場所をはじめ、銃剣 とブルドーザーで強制接収をされ、基地建設がなされた。」

21 「沖縄は、27年間、米軍の施政権下から外された時には、日本国民でもない、アメリカ国民でもないなかで、べトナム戦争を、 沖縄の基地を使って戦争をしたわけなんです……本の戦後の平和と高度経済成長は、沖縄が 27 年間、米軍が自由に使うこと によって、私は成り立ったもんだというふうう思っております。」

22 「回、海上での銃剣とブルドーザーの様相を呈してきていることは、やはり沖縄県民の自己決定権のなさについては、あの 70 年前も今回もそうは違わないなといらようなことを、今度は米軍ではなく、日本政府が法律を盾に取ってやることである。」

23 「れは私たち沖縄県民が、その目や耳、肌に戦争のもたらす悲惨さを鮮明に記憶しているからであり、戦争の犠牲になられ 
Furthermore, Onaga also frequently links recent crimes committed by US military service members with broader historical contexts, redeploying them as powerful symbols for the injustice and oppression historically suffered by Okinawa at the hands of the US. ${ }^{24}$ One example of this is violence against women by US military servicemen. In a speech at a prefectural gathering in June 2016, following the sexual assault and murder of a twenty-yearold Okinawan woman by a US base employee that April, Onaga connects individual crimes against women committed by US service members with the presence of the US military as a whole:

This kind of inhumane and cowardly crime that violates women's rights is absolutely unforgivable and I feel strong indignation [...]. As Governor, I have strongly requested a review of the US-Japan Status of Forces Agreement in order to protect Okinawans' lives, assets, dignity, human rights, and for the safety and security of future children and grandchildren. ${ }^{25}$

(Onaga 2016)

Onaga draws a causal relationship between the rape and the US military base presence, positioning the individual crime as symptomatic of the asymmetrical power dynamic between Okinawa and the US military.

As the above examples illustrate, Onaga has leveraged the strong collective memory of wartime atrocities, linking these historical instances of injustice to the current base dispute to bolster his anti-base position. The findings from this analysis align with those of Inoue's (2007) study on the activist work by a grassroots anti-base organisation centred in Henoko. Inoue's study found that the Henoko residents' "oppositional collective consciousness" and strongly negative attitude toward the US military was grounded in their collective memory of historical issues of subjugation, war and adversity (Inoue 2007, 144). By evoking these memories, Onaga appeals to the deep sense of loyalty and solidarity of a people who have been subjected to the violence of ground warfare and prolonged hardship.

\section{CONCLUSION}

The US base controversy in Okinawa has been a polarising and highly contentious issue in local Okinawan politics in recent years. Central to the base debate is the perception of Okinawa's position in relation to mainland Japan, and the interplay of shared notions of collective identity with politics. Takeshi Onaga led a successful campaign in the 2014 Okinawan gubernatorial election as an independent anti-base candidate. Whilst many anti-base activists touted the election as a clear reflection of unanimous, prefecturewide anti-base sentiment, I have argued that the reality is more complex.

\footnotetext{
24 Another widely recognised symbol of Okinawan sacrifice and victimhood is the Himeyuri Student Nurse Corps Unit. The unit was comprised of over 200 female students from two Okinawan high schools during the Battle of Okinawa. They were deployed as student nurses for Japanese soldiers at the frontline, and the majority perished in the last days of the battle (Angst 2001, 250). 
Fissures and frictions between different interest groups still exist. The US base presence and the Futenma relocation dispute-the most important issue of the 2014 election-directly involves environmentalists, landowners, pacifists and individuals spanning the political spectrum. Onaga successfully leveraged the notion of a collective Okinawan identity to bridge ideological divides between these diverse groups and mobilise political support. The fact that one's affiliation with a particular political party or ideology can be eclipsed by an attachment to the imagined community of Okinawa shows the power of historical representation and identity in local politics.

It is precisely because the base issue intersects with so many different interests that an "All Okinawa" unity is possible. Okinawan identity has been continually defined, redefined and expanded throughout history. It is often inextricably linked to a political function and always encompasses Okinawa's selfperception of its position vis-à-vis mainland Japan. Agreements between the US and the central Japanese government legitimise the US military presence in the island prefecture (in spite of local protests), and the Futenma dispute has driven the question of Okinawa's place within Japan to the forefront. In essence, this article aimed to answer the question: what does it now mean to be Okinawan and how does this play out in local politics?

Okinawa belongs to Japan but is simultaneously separate from it. The seemingly paradoxical and dual nature of Okinawan identity affords local politicians like Onaga great potential for leveraging local identity and related sentiment when politically advantageous. In the context of the US base controversy, Onaga uses a romanticised version of a pacifist Ryukyuan legacy and stories of suffering from war and colonialism to emphasise Okinawa's different-and tragic-history compared with mainland Japan. The three main threads that underpin the prevalent version of Okinawan history include: (1) prosperity and peace during the Ryukyu Kingdom days, (2) oppression, destruction and tragedy at the hands of Japanese colonialism, and finally (3) a united front of resistance and struggle against inequality and continued suffering. This account of history under-represents the relationship between Tokyo and Okinawa and the will of the people to join (or return to) the Japanese state at different times throughout history. As a result, the story of Okinawa's relationship with Japan is one of one-sided, continual oppression and victimhood. Not only does this narrative present as a persuasive argument to Tokyo for freedom from a disproportionate US base presence, but it also emotively ties diverse groups of people within the prefecture together under one collective identity. In reality, it is the anti-colonial struggle that has given rise to the present form of Okinawan collective identity. Seen in this light, the power of the narrative deployed by Onaga lies in its seamless construction: it does not appear carefully crafted, but seems to have been inherited from Ryukyuan ancestors.

This article has illustrated how Onaga taps into this shared sense of attachment and community to promote engagement and support for his political agenda. Onaga effectively draws upon a rich stock of stories, cultural symbols and memories to bind diverse individuals and communities into one "All Okinawa" 
identity. In doing so, Onaga also builds up his own symbolic and cultural capital to gain greater electoral support. My analysis of the 2014 gubernatorial election reveals the immense unifying power of collective identity which can override clashing political ideologies. This article has also shown how a deep understanding of Okinawan social consciousness can provide an abundance of symbolic resources and persuasive power in the local electorate. Given the success of Onaga's unifying strategy, backed by the innovative use of social media (particularly Twitter), it will be interesting to observe how Onaga and other candidates approach the upcoming gubernatorial election towards the end of 2018.

\section{APPENDIX: OKINAWAN HISTORY TIMELINE}

1372

China's Ming Dynasty sends a representative to the Ryukyu Islands to demand tributes to China

All three kingdoms on the main island of Okinawa have established diplomatic relations with, and pay tribute to, China

Shō Hashi [尚 巴志; 1372-1439] unifies the three kingdoms on the main island of Okinawa and exerts influence across the Ryukyu archipelago, establishing the Ryukyu Kingdom. Vernaculars across the archipelago are diverse and often mutually unintelligible

Satsuma Invasion: the Japanese Satsuma clan invades the Ryukyu Kingdom, a trading hub with strong links with Taiwan, Southeast Asia, China and Japan. The Ryukyu Kingdom becomes a vassal state under the Satsuma domain, while maintaining its tributary relationship with China

1872 Japan moves to formally annex the Ryukyu Kingdom by reconfiguring the kingdom as a domain of Japan (Ryukyu domain)

Japan sends a military envoy to Taiwan in response to the massacre of shipwrecked Ryukyuans by Taiwanese aboriginal groups, as an expression of sovereignty over the Ryukyu Islands

Japan's Meiji government prohibits the tributary relationship between Ryukyu and Qing-dynasty China

Annexation of Ryukyu Kingdom to mainland Japan; Ryukyu Kingdom is renamed Okinawa and becomes a prefecture of Japan. The Meiji government rolls out assimilation measures, including language standardisation and education reforms that emphasise Japanese nationalism, but the ruling elite resist and maintain strong pro-China sentiment more positive following Japan's victory in the Sino-Japanese War, due to perceived economic advantage 

purposes of military use during the Pacific War [1941-45] through a "de-Japanization"/"Ryūkyūanization" policy, which sought to construct and promote a Ryukyuan identity that was independent from Japan.

The Battle of Okinawa is fought between US and Japanese forces from April to June, resulting in an estimated 130,000 civilian deaths; the US occupation of Okinawa and mainland Japan (and construction of US bases) begins

$1950 \mathrm{~s}$

1995

1996

Oct 2015

Nov 2015

Dec 2015

Mar 2016

Dec 2016

Apr 2017
Reversion movement begins to gain traction in Okinawa after the end of the US occupation of mainland Japan

Okinawa Reversion Agreement takes effect; US returns Okinawa Prefecture to Japan

Gang rape of twelve-year-old Okinawan girl by three US military service members who were serving at Camp Hansen; following public outcry, SACO is established to reduce impact of US military presence on Okinawan residents

Japanese and US governments agree to close the US military base at Futenma due to safety concerns for residents of Ginowan city

Governor Nakaima gives approval for the landfill project at Henoko, allowing construction of the replacement facilities for the Futenma base to begin

Takeshi Onaga is elected as governor on an anti-base platform, defeating the incumbent Hirokazu Nakaima, after a successful campaign centred on the notion of Okinawan identity taking precedence over political ideology

Onaga revokes approval for landfill at Henoko, passed during Nakaima's time in office, thereby suspending construction of the Henoko base

Central Japanese government files lawsuit against Okinawa Prefecture for Onaga's revocation of landfill approval. Japan's Ministry of Land, Infrastructure, Transport and Tourism suspends Onaga's cancellation of landfill approval

Okinawa Prefecture files a lawsuit against the central Japanese government, claiming that the Ministry of Land, Infrastructure, Transport and Tourism illegally suspended Onaga's cancellation

Tokyo suspends construction at Henoko base to allow for talks with Okinawan authorities

Supreme Court of Japan overturns Onaga's revocation of approval

Construction at Henoko recommences following the Supreme Court ruling

(n)


Jul 2017

Mar 2018

\section{GLOSSARY}

MCAS

Okinawa

沖縄

Okinawa Main Island 沖縄本島

Ryukyu archipelago

琉球列島

Ryukyu Islands

Ryukyu Kingdom

琉球王国

Ryukyu domain

琉球藩

Ryukyuan

SACO

SOFA

琉球諸島

\section{Marine Corps Air Station}

The term can either refer to Okinawa Main Island or Okinawa Prefecture. The use of 'Okinawa' in this article refers to Okinawa Prefecture

The largest island in Okinawa Prefecture, where the capital Naha is located

A geographical reference to the chain of islands extending from the south of Kyushu to Taiwan (see map, Figure 1)

This geopolitical term encompasses the Okinawa and Sakishima Islands only, excluding the Amami Islands (see Figure 1)

A monarchical regime centred in Shuri on Okinawa Main Island that once exerted control across the entire Ryukyu archipelago from the beginning of the 15th century

The feudal domain that became Okinawa Prefecture after its annexation

This term is used to mean 'indigenous Okinawan'

Special Action Committee on Okinawa, established in 1995 to examine ways to reduce the burden of bases on Okinawan residents

Status of Forces Agreement; governs how US military forces, related personnel and civilians are to be treated by Japanese authorities for any crime 


\section{REFERENCES}

Angst, L. 2001. "The Sacrifice of a Schoolgirl: The 1995 Rape Case, Discourses of Power, and Women's Lives in Okinawa”. Critical Asian Studies 33 (2): 243 66.

Anderson, B. 2006. Imagined Communities: Reflections on the Origin and Spread of Nationalism. New York: Verso.

Anderson, M. 2009. "Emergent Language Shift in Okinawa". PhD thesis, The University of Sydney. Accessed 17 January, 2018. https://ses.library.usyd. edu.au/handle/2123/15513/.

Arakawa, A. 2013. "Confronting Home-Grown Contradictions: Reflections on Okinawa's 'Forty Years Since Reversion””. The Asia-Pacific Journal 25 (1). Accessed 1 November, 2017. http://apjjf.org/2013/11/25/Arakawa-Akira/ 3960/article.html/.

Arasaki, M. 2001. "The Struggle against Military Bases in Okinawa-Its History and Current Situation". Inter-Asia Cultural Studies 2 (1): 101-08. https://doi. org/10.1080/14649370120039506/.

Augustine, M. 2015. "Dividing Islanders: The Repatriation of 'Ryūkyūans' from Occupied Japan". In Japan as the Occupier and the Occupied, edited by C. de Matos and M. Caprio, 206-25. New York: Palgrave Macmillan. https://doi.org/10.1057/9781137408112_11/.

Calder, K. 2004. "Securing Security through Prosperity: The San Francisco System in Comparative Perspective". The Pacific Review 17 (1): 135-57.

Chanlett-Avery, E. and I. Rinehart. 2014. "The U.S. Military Presence in Okinawa and the Futenma Base Controversy". Current Politics and Economics 23 (4): 467-91.

Clarke, H. 2015. "Language and Identity in Okinawa and Amami: Past, Present and Future". In Handbook of the Ryukyuan Languages: History, Structure, and Use, edited by P. Heinrich, S. Miyara and M. Shimoji, 631-47. Berlin: De Gruyter Mouton. https://doi.org/10.1515/9781614511151.631/.

Cooley, A. and K. Marten. 2006. "Base Motives: The Political Economy of Okinawa's Antimilitarism”. Armed Forces and Society 32 (4): 566-83. https:// doi.org/10.1177/0095327X05283557/.

Heinrich, P., M. Shinso and M. Shimoji. 2015. Handbook of the Ryukyuan Languages: History, Structure and Use. Berlin: De Gruyter Mouton. https:// doi.org/10.1515/9781614511151/.

Hook, G., R. Mason and P. O'Shea. 2015. Regional Risk and Security in Japan: Whither the Everyday. New York: Routledge.

Hunter, W. C. 2012. “The Good Souvenir: Representations of Okinawa and Kinmen Islands in Asia”. Journal of Sustainable Tourism 20 (1): 81-99. https://doi.org/ 10.1080/09669582.2011.586571/. 
Inoue, M. 2007. Okinawa and the U.S. Military: Identity Making in the Age of Globalization. New York: Columbia University Press. https://doi.org/ 10.7312/inou13890/.

Liu, J. H. and D. J. Hilton. 2005. "How the Past Weighs on the Present: Social Representations of History and Their Role in Identity Politics". British Journal of Social Psychology 44 (4): 537-56. https://doi.org/10.1348/ 014466605X27162/.

McCormack, G. 2007. Client State: Japan in the American Embrace. London: Verso.

. 2014. "The End of the Postwar? The Abe Government, Okinawa, and Yonaguni Island". The Asia-Pacific Journal 12 (3). Accessed 1 November, 2017. https://apjjf.org/2014/12/49/Gavan-McCormack/4233.html.

McCormack, G. and S. O. Norimatsu. 2012. Resistant Islands: Okinawa Confronts Japan and the United States. Lanham: Rowman and Littlefield.

Mie, A. 2013. "Election Campaigning Takes to Net". Japan Times. Accessed 2 March, 2018. https://www.japantimes.co.jp/news/2013/04/11/national/politicsdiplomacy/election-campaigning-takes-to-net/.

Ministry of Internal Affairs and Communication [総務省]. 2013. “Kōshoku senkyohō no ichibu o kaisei suru hōritsu no shikō ni tsuite (tsūchi) [公職選挙法の一部 を改正する法律の施行について (通知) ]”. Accessed 8 March, 2018. http:// www.soumu.go.jp/senkyo/senkyo_s/naruhodo/img02/pdf/000223260.pdf.

Mizuno, N. 2009. "Early Meiji Policies towards the Ryukyus and the Taiwanese Aboriginal Territories". Modern Asian Studies 43 (3): 683-739. https://doi. org/10.1017/S0026749X07003034/.

Nakano, Y. [中野 好夫] and M. Arasaki [新崎 盛睴]. 1976. Okinawa sengoshi [沖縄 戦後史]. Tokyo: Iwanami Shoten [岩波書店].

Noakes, J. A. and H. Johnston. 2005. "Frames of Protest: A Road Map to a Perspective". In Frames of Protest: Social Movements and the Framing Perspective, edited by J. A. Noakes and H. Johnston, 1-32. Maryland: Rowman and Littlefield.

Okinawa Election Administration Committee [沖縄県選挙管理委員会]. 2015. Senkyo kanri iinkai nenpō [選挙管理委員会年報]. Accessed 1 December, 2017. http:// www.pref.okinawa.lg.jp/site/senkan_i/documents/h26nenpou.pdf.

Okinawa Prefectural Government [沖縄県庁]. 2015. “Shiisā [シーサー]”. Okinawa Prefecture. Accessed 3 September, 2017. http://www.pref.okinawa.jp/site/ kodomo/sumai/machinami/minka/shisa.html.

. 2016. “Okinawa no beigun oyobi jieitai kichi [沖縄の米軍及び自衛隊基地]”. Okinawa Prefecture. Accessed 20 March, 2017. http://www.pref.okinawa.jp/ site/chijiko/kichitai/toukeisiryousyu2703.html.

. 2018. “Suikei jinkō [推計人口]". Okinawa Prefecture. Accessed 18 February, 2018. http://www.pref.okinawa.jp/toukeika/estimates/estimates_ suikei.html.

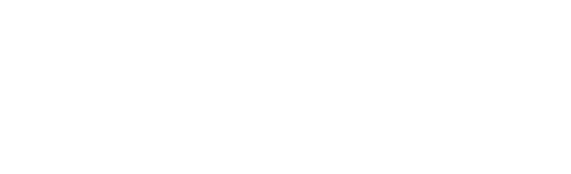

.

$$
\text { . }
$$


Onaga, T. [翁長 雄志]. 2014a. “Chiji shūnin aisatsu [知事就任挨拶]”. Speech [transcript]. Okinawa Prefectural Assembly, 12 December. Accessed 10 May, 2017. http://www.pref.okinawa.jp/site/chijiko/hisho/kense/chiji/ message/back/h2612/message.html.

. 2014b. “Kichi mondai ni tsuite: Onaga Takeshi Okinawa-ken chiji kōhō [基 地問題について 翁長雄志沖縄県知事広報]”. YouTube video, 0:54, posted by “Onaga Takeshi [翁長雄志]," 12 November. Accessed 2 April, 2017. https:// www.youtube.com/watch?v=84qJ74hXhbI.

.2015a. “Heiwa sengen [平和宣言]”. Speech [transcript]. Itoman, Okinawa, 23 June. Accessed 28 April, 2017. http://www.huffingtonpost.jp/2015/06/23/ okinawa-heiwa-sengen_n_7641970.html.

. 2015b. “Kuni no teiso o uketa Onaga chijii kisha kaiken [国の提訴を受け た翁長知事記者会見]”. Press conference [transcript]. Naha, Okinawa, 17 November. Accessed 27 April, 2017. https://ryukyushimpo.jp/news/ entry-173561.html.

. 2015c. “Nihon no dokuritsu wa shinwa ka [日本の独立は神話か]”. Speech [transcript]. Naha, Okinawa, 2 December. Accessed 6 May, 2017. http:// www.okinawatimes.co.jp/articles/-/21524.

2015d. "Okinawa Gov. Takeshi Onaga Goes to Washington: My Message on U.S. Bases”. Press conference. Foreign Correspondents' Club of Japan, 20 May. YouTube video, 1:12:09, posted by “日本外国特派員協会 会見映像 才 フイシャルサイトFCCJchannel,” 20 May. Accessed 24 May, 2017. https://www. youtube.com/watch?v=9Gr6l1Depng.

.2015e. “Onaga chiji aisatsu [翁長知事挨拶]”. Speech [transcript]. Prefectural Citizens' Assembly, 17 May. https://ryukyushimpo.jp/news/prentry243054.html.

. 2015f. "Takeshi Onaga (his original voice in Japanese): Okinawa Face-off Deepens.” Press conference. Foreign Correspondents' Club of Japan, 24 September. YouTube video, 1:06:57, posted by “日本外国特派員協会 会 見映像オフィシャルサイトFCCJchannel,” 24 September. Accessed 10 May, 2017. https://www.youtube.com/watch?v=J-Gg-Lo851Q.

. 2016. “Kenmin taikai: Onaga chiji aisatsu [県民大会 翁長知事挨拶]." Speech [transcript]. Naha, Okinawa, 20 June. Accessed 10 May, 2017. http://www.okinawatimes.co.jp/articles/-/5943.

Ota, M. [大田 昌秀]. 1996. Okinawa: sensō to heiwa. [沖縄 戦争と平和]. Tokyo: Asahi Shinbunsha [朝日新聞社].

Reicher, S. and N. Hopkins. 2001. Self and Nation. London: Sage.

Ryūkyū Shimpō [琉球新報]. “Shin chiji ni Onaga-shi: Nakaima-shi ni 10-man hyōsa [新知事に翁長氏、仲井間氏に10万票差]”. 17 November. Accessed 3 May, 2017. https://ryukyushimpo.jp/photo/prentry-234626.html. 
Shimada, N. [島田 信幸]. 2016. “Okinawa-ken no haiso kakutei: saikōsai, jōkoku o kikyaku [沖縄県の敗訴確定 最高裁、上告を棄却]”. Mainichi Shimbun. Accessed 1 September, 2017. http://mainichi.jp/articles/20161220/k00/ 00e/040/204000c.

Siddle, R. 1998. "Colonialism and Identity in Okinawa before 1945". Japanese Studies 18 (2): 117-33. https://doi.org/10.1080/10371399808727647/.

2003. "Return to Uchinā: The Politics of Identity in Contemporary Okinawa". In Japan and Okinawa: Structure and Subjectivity, edited by G. Hook and R. Siddle, 133-47. London: Routledge Curzon.

Takara, K. [高良 倉吉]. 1980. Ryūkyū no jidai: ōinaru rekishizō o motomete [琉球の 時代: 大いなる歴史像を求めて]. Tokyo: Chikuma Shobō [筑摩書房].

Tanji, M. 2006. Myth, Protest and Struggle in Okinawa. New York: Routledge.

Tanji, M. and D. Broudy. 2017. Okinawa Under Occupation: McDonaldization and Resistance to Neoliberal Propaganda. Singapore: Palgrave Macmillan. https://doi.org/10.1007/978-981-10-5598-0/.

Twitter Japan. 2016. Twitter post (“Okagesama de Nihon kokunai... [おかげさまで日 本国内......]”), 1 November, 8:01pm. Accessed 10 March, 2018. https:// twitter.com/TwitterJP/status/793649186935742465/. 


\section{"Watashi-tachi wa ningen da!": A Corpus-Assisted Analysis of a Non-Human Character in the Anime Series 'From the New World'}

\section{KELVIN K. H. LEE}

The University of Sydney

\section{ABSTRACT}

This paper focuses on how social meanings indexed by language use in the real world can be recontextualised in telecinematic texts such as anime to construct and convey different aspects of a character's identity. In a case study of the science-fiction anime series, From the New World (Shinsekai Yori; 2012 13), the paper analyses three corpora comprised of dialogue from the series in order to shed light on the discursive construction of the non-human character Squealer. A non-human character was selected to minimise the influence of preconceptions about identity. Drawing on Androutsopoulos's (2012) three-level film analysis framework and Bucholtz and Hall's (2005) identity framework, the approach incorporates both computerised and manual discourse analysis. The computer-facilitated keyword analysis provides initial insights into the character's demographic information and speech style, showing the key linguistic features used by the character's species, and by extension, the focal character. This is complemented by a detailed analysis of dialogue from selected scenes which shows how various aspects of the character's identity are expressed using different linguistic devices in different contexts. The analysis demonstrates that shifts between the use and non-use of certain linguistic features serve to foreground different aspects of a character's identity-namely, stances and presentational personae. By integrating corpus linguistic analysis with scene-based analysis drawing on sociolinguistic concepts, the study shows how we can gain insights into telecinematic characters' identities through language. The paper also highlights issues encountered in applying corpus linguistic methodologies to analyses of Japanese language, which may be of use to future researchers and software developers in this area.

\section{KEYWORDS}

anime; corpus linguistics; discourse analysis; frequency analysis; indexicality; keyword analysis; linguistic repertoire; language; linguistics; sociolinguistics; social and cultural identity; speech style shift

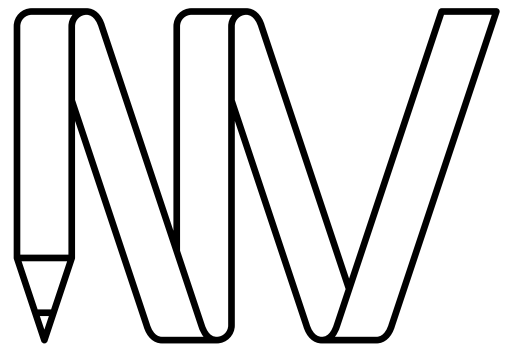

NEW

VOICES

IN JAPANESE STUDIES

JAPANFOUNDATION \&

BRINGING JAPAN TO YOU

To link to this article:

https://doi.org/10.21159/nvjs.10.03

\section{ISSN 2205-3166}

New Voices in Japanese Studies is an interdisciplinary, peer-reviewed journal showcasing the work of emerging scholars from Australia and New Zealand with research interests in Japan.

All articles can be downloaded free at newvoices.org.au

(c) The Japan Foundation, Sydney and Kelvin K. H. Lee, 2018

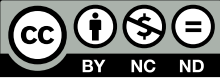

This work is licensed under a Creative Commons Attribution-NonCommercialNoDerivatives 4.0 International License. 


\section{INTRODUCTION}

This paper examines how social meanings prototypically indexed by language use in the real world are recontextualised in the fictional world of telecinematic texts such as anime to convey various aspects of character identity. ${ }^{1}$ Using the anime series From the New World [新世界より; 2012-13] as a case study, it explores how sociolinguistic differences are used as a resource for the discursive construction of characters, with analysis centred on the dialogue of a non-human character from the series. The study uses a mixedmethod approach facilitated by the use of corpus linguistics, which is an emerging form of investigation involving the computerised analysis of a large volume of selectively compiled linguistic data known as a 'corpus'. To date, corpus linguistics has been used in a range of linguistic studies focusing on characterisation (e.g., Bednarek 2011, 2012) and other features (e.g., Vignozzi 2016) in (mostly English) telecinematic texts. ${ }^{2}$ The corpus linguistic approach is slowly growing in a number of Japanese linguistic research areas, including linguistic register (e.g., Fujimura et al. 2012), phonetics and phonology (e.g., Maekawa 2015) and educational linguistics (e.g., Abe 2016; Lee and Nakagawa 2016; Miyata and MacWhinney 2016). However, corpus linguistics seems to be completely unused in any prior studies on discourse in Japanese telecinematic texts such as anime, television dramas and feature films. Based on this shortfall, the key purpose of this paper is to demonstrate how corpus linguistics can be used in a mixed-method (socio)linguistic study to examine the ways in which social meanings indexed by language use in the real world are recontextualised for the purpose of constructing fictional characters.

\subsection{Anime and Character Analysis}

As a burgeoning popular phenomenon, anime receives a substantial amount of scholarly interest in a number of areas, including gender studies (e.g., Saito 2014), cultural studies (e.g., Fennell et al. 2012), language pedagogy (e.g., Armour and Iida 2014) and fan-translation/fan-subtitling (e.g., Lee 2011). However, despite the extensive interdisciplinary study of anime, linguistic examination of discourse in anime and other Japanese telecinematic texts remains limited. Among the few existing linguistic studies of identity in Japanese telecinematic texts, there are a number of studies that examine character identity (e.g., Hiramoto 2013; Hollis 2014; Toh 2014). Hiramoto (2013), for example, draws on Kinsui's $(2000,2003)$ notion of yakuwarigo (役割語; 'role language') to examine how pronouns and sentence-final particles are used to construct the imagined identities of the female character archetypes in the anime series Cowboy Bebop [カウボーイビバップ; 1998]. ${ }^{3}$ Hollis (2014), meanwhile, examines how sentence-final particles are used to construct gendered identities in two anime series: Toradora! [とらドラ!; 2008] and 'Reaching You' [君に届け; 2011]. Although these studies offer valuable

1 'Telecinematic discourse' (or 'telecinematic text') was coined by Piazza et al. (2011) as an umbrella term for the type of discourse found in films and television series (i.e., fictional, scripted discourse).

2 Vignozzi (2016) examines the multimodal semiosis of idioms in Disney films. The study demonstrates that visual representation of idioms in dialogue helps generate audio-visual humour that entertains the audience.

Even when they are not used to elicit laughter, these audio-visual puns can help "make the movie[s] more winsome and captivating" (Vignozzi 2016, 260).

3 A definition of yakuwarigo and other Japanese terms can be found in the glossary. 
insights into how language (specifically, sentence-final particles and pronouns) is used to construct and convey gendered identities, the focus on gender can be limiting since gender is but one aspect of (character) identity that is discursively constructed.

The identity of both real and fictional beings can be shaped by physical traits such as age, gender or race. However, identity can also be shaped by intangible traits such as one's personality, stances and affiliations, and by the manner in which one may choose to present oneself. Richardson (2017) observes this phenomenon in dialogue from (primarily American and British) television dramas, which can be seen as parallel with anime due to their shared telecinematic nature:

[T] he speech of any character, at any time, is a performance of that character as a 'persona,' with plausible traits of identity (regional/national origins; gender, ethnicity, age - as well as rudeness, sentimentality and other kinds of personality traits). [...] The fact that characters' lines are mostly interactive, i.e., that speech in drama is realised as dialogue, affords a range of possibilities that can be exploited for communicative effects, specifically about the acceptance or otherwise [of] identities and stances that characters project, through a combination of wording and delivery in context.

(Richardson 2017, 40-41)

This study adopts Richardson's (2017) stance on language use by fictional characters, which regards characters as though they are 'real' people by examining them with the identities and traits of 'real' people in mind.

Although fictional characters are representative of 'real' people to some degree, they do not have to resemble specific humans, nor do they have to be humanoid in form. As Richardson (2010) explains:

Narratives need characters, but there is no requirement that the characters should be human beings. They can be whatever imagination allows and the medium affords, though human nature is always the point of reference.

(130, emphasis in original)

The examination of non-human characters offers a way for researchers to respond to the aforementioned limitations of identity analysis that focuses on gender. In human characters, major social "categories" such as age, gender and race are easily communicated and interpreted by visual means (Bucholtz and Hall 2005). This results in "the tendency to 'bend' texts so that the analysis fits a pre-determined stance" (Wagner and Lundeen 1998, in Mandala 2011, 6). In contrast, the same social categories are less predictable and more difficult to ascertain in non-human characters, which means that analysis of nonhuman characters is less likely to be influenced by preconceptions. This study examines the dialogue of one non-human anime character, Squealer (スクイ ーラ), to demonstrate how language use can provide insight into character identity. In doing so, it also illustrates that language is a salient tool for identity construction in telecinematic characters, particularly in the absence of easily parsable visual cues. 


\section{INTRODUCING FROM THE NEW WORLD}

The data for this study consists of the dialogue from all 25 episodes of the science-fiction anime series, From the New World. The series is adapted from a Japanese novel of the same name, written by Yùsuke Kishi (貴志 祐介) and published in 2008 by Kodansha. It was directed by Masashi Ishihama (石浜 真史) and aired in Japan between September 2012 and March 2013. The story is set in Japan, a thousand years in the future (c. 3012), where all humans possess a power known as 'Juryoku' which allows them to telekinetically manipulate almost everything in their environment, effectively rendering technology obsolete. The narrative focuses on a human female protagonist, Saki Watanabe (from age 12 to 26 in the main story, 40 in the Epilogue), and her friends, who live in an idyllic village isolated from the outside world. Over time, Saki and her friends come to learn about the true nature of their world, including the dark history that has shaped their current society.

From the New World was selected as the data source as it depicts a world in which a society of a non-human species co-exists and interacts with a human society, thereby allowing analysis of a non-human protagonist acting within a human-centric social and linguistic frame. The non-human species in question is the 'Bakenezumi', who appear to be naked mole-rats. The anthropomorphic Bakenezumi live in eusocial colonies, similar to ants or bees, under the control of a queen. They communicate amongst themselves using their own language, which is presented as a mixture of squeaking and grunting vocalisations that are intelligible to neither the viewer nor the human characters in the series. However, each colony has at least one envoy who is fluent in human language and can directly communicate with human officials. These Bakenezumi are able to adeptly use human language (in this case, Japanese) to express aspects of their identity and convey their place in a world dominated by humans.

\section{FRAMEWORK}

The mixed-method analysis of Squealer's dialogue adopted in this paper begins with a quantitative analysis of the character's linguistic repertoire, based on a computerised keyword analysis. This is supplemented below with a manual analysis of dialogue involving Squealer, Saki and her human male friend Satoru. The discussion of findings about Squealer's language use draws on Bucholtz and Hall's (2005) identity framework, described in more detail below.

\subsection{A Sociocultural Approach to Identity: The Indexicality Principle}

The overarching approach used for the analysis of identity in this study is the framework proposed by Bucholtz and Hall (2005), which synthesises research in several fields to offer a general sociocultural linguistic perspective on identity. In this approach, identity is regarded as an individual subscription to categories of membership that are observed in discourse, rather than as a static and individualistic attribute ascribed by society and internalised 
by the individual. The strength of this framework is that it views identity as "intersubjectively rather than individually produced and interactionally emergent rather than assigned in an a priori fashion" (Bucholtz and Hall $2005,587)$. Based on this perspective, the framework proposes five principles for analysing "the social positioning of self and other" $(2005,586)$. These are "emergence", "positionality", "indexicality", "relationality" and "partialness" (2005, 587-607). This study draws primarily on the indexicality principle of the framework, which relates to the use of language to discursively construct identity position. Bucholtz and Hall argue that the indexicality function of language relates strongly to normative language use and draws heavily on linguistic ideologies regarding "the sorts of speakers who (can or should) produce particular sorts of language” $(2005,594)$.

It must be noted that Bucholtz and Hall's (2005) framework is designed for the purpose of analysing and examining the identities of real people. Therefore, by applying this framework, the examination and discussion of language in this study treats fictional character(s) as though they are 'real' people who are using language with volition. While the characters may be fictional constructs, it is nonetheless possible to make inferences about "the broad demographic characteristics the character(s) inhabit" and "the personality quirks and traits (they) exhibit” (Queen 2015, 155) using this framework.

\subsection{Three-Level Framework: Repertoires, Characters and Scenes}

The approach used for analysing characterisation is adapted from Androutsopoulos' (2012) three-level framework for sociolinguistic film analysis, which draws on the concept of repertoire (Gumperz 1964). Linguistic repertoires can be defined as a summary of linguistic codes used by a community (i.e., sociolects) or an individual (i.e., idiolects). When examining telecinematic texts, it is possible to think of the linguistic repertoire of an entire television series or film as the sum of the linguistic codes used by all of the characters in that series or film. Likewise, a character is a summary of how they speak in the film or television series they appear in (Androutsopoulos 2012, 305). Examinations of linguistic repertoire at the level of individual characters can be complemented by examining selected scenes. This allows for more focus on how characters use language in particular contexts and how consistently they use their established linguistic repertoire(s), which can help produce a more holistic picture of the character (Androutsopoulos 2012, 306).

In this study, repertoire analysis is used to profile the salient or dominant speech patterns-that is, language that is the norm or default for these characters in relation to a variety of social and contextual factors-of humans and Bakenezumi. In order to conduct this analysis, corpus linguistic software and the following three electronic corpora are used:

- FNW: a 59,282-word corpus of transcripts for all 25 episodes of From the New World, developed from Japanese subtitle files downloaded from https://kitsunekko.net/. This corpus includes speaker attributions (e.g., Squealer, Saki, Teacher) written in romanised Japanese or English. 
- HUMANS: a 49,705-word corpus of dialogue by all human characters, extracted from the FNW corpus and including speaker attributions.

- BAKENEZUMI: a 6,997-word corpus comprising the dialogue of Bakenezumi characters who are capable of human speech (e.g., Squealer, Kirōmaru), extracted from the FNW corpus (excluding speaker attributions). ${ }^{4}$

By comparing the linguistic markers in the HUMANS and BAKENEZUMI subcorpora, it is possible to determine the most salient linguistic codes used by each species. To achieve this, corpus linguistic methodologies of keyword analysis are used, as detailed below.

\subsection{Corpus Linguistic Analysis: A Brief Introduction}

Corpus linguistic software allows for a summative analysis of the linguistic repertoire in a film or television series. ${ }^{5}$ To uncover patterns of language use, this study uses frequency and keyword analysis, which can be achieved using corpus linguistic software. Keyword analysis requires using software to produce lists of words that occur in a corpus, along with their frequencies. The software is then able to compare the frequencies in the wordlist of one corpus against another. This allows the program to generate a list of words or word-forms/clusters that are statistically significant in a node corpus (i.e., the corpus that is being analysed) compared with a reference corpus (i.e., the corpus being used as a point of comparison or comparative norm/standard) (Baker 2006; Scott and Tribble 2006). The resulting words are referred to as keywords due to their unusually high frequency in the node corpus relative to the reference corpus, as determined by their statistical significance. ${ }^{6}$ The unusually high frequency of a word indicates its keyness or salience in the node corpus (compared with the reference corpus).

Since corpora are encoded electronically, and due also to the large volumes of data involved, computer processing is the most efficient and realistic mode of corpus analysis (Anthony 2009; Baker 2006). However, the use of automated computational analysis is not without problems, especially when analysing a language such as Japanese that has received limited attention from corpus linguists. During this study, three key methodological issues emerged. One is that corpus linguistic software can only recognise words if their boundaries are determined using space- $-\mathrm{a}$ feature that is rarely used in Japanese writing, if at all (Benešová and Birjukov 2015; Den n.d.). Therefore, to prepare the

4 Since the HUMANS and BAKENEZUMI corpora are derived from a larger corpus (i.e., the FNW corpus), they are referred to as subcorpora (sing., 'subcorpus').

5 The corpus linguistic software used in this study is AntConc (Anthony 2016).

6 To determine statistical significance, the software carries out statistical tests on each word (using the chi-

squared or log-likelihood test) and then assigns a $\mathrm{p}$ (or probability) value. The lower the p-value, the more likely that the (high) presence of the word is less random and therefore more likely to be due to the author's/speaker's choice to use the word more frequently. Since AntConc does not allow adjustment of the p-value, the equivalent keyness (or $\mathrm{G}^{2}$ ) value is used as a cut-off (see http://ucrel.lancs.ac.uk/llwizard.html for more detail): 
Japanese-language corpora for analysis, the text first needs to be segmented using segmenting software-here, SegmentAnt (Anthony 2017). SegmentAnt was chosen as it was specifically designed to segment large volumes of Japanese (and Chinese) texts. Despite this, the resulting segmentation was characterised by numerous inconsistencies. Corrections were made to the inconsistent or incorrect segmentations in the FNW corpus, using word and phrase structures outlined in Siegel et al. (2016) as a guide.

The second issue relates to terminology, which has some implications for clear discussion of the findings. Up until this point, the term 'word' has been used when referring to lexical units in written Japanese. However, what the corpus software identifies as 'words' consists of lexical words (e.g., です), grammatical particles (such as $の$ and に), affixes (such as 一ます and お-) and other bound morphemes. ${ }^{8}$ This is a result of the way in which the segmentation software parses and then segments the Japanese text, which often involves separating affixes from their word stems. For the sake of consistency and clarity, the term 'word(s)' is used to refer to lexical words and grammatical particles, and 'morpheme(s)' is used to refer to affixes and bound morphemes.

The third issue is that corpus software creates wordlists based on the form rather than the function or meaning of words and morphemes. This means that the software is unable to distinguish between words and morphemes that are polysemous in nature. For example, ' $d e$ ' (で) is one of the most frequently occurring morphemes in the FNW corpus. However, the software does not distinguish between the many functions of 'de', which include its use as a location marker, as an allomorph of the '-te' (-て) suffix, or as the conjunctive variant of the copula. Additionally, ' $d e$ ' can also be considered a marker of honorific language, as the segmenting software separates the super-polite copula 'degozaru' (でござる) and its inflections, resulting in 'de' and 'gozaru' being treated as separate words. For this reason, it is not possible to make conclusions or generalisations about the use of homographic morphemes in the FNW corpus - or by extension, any Japanese-language corpus data that has undergone computerised segmentation-without undertaking further analysis of their meanings and functions. This is a known issue in corpus linguistics that also affects homographs in corpora in other languages. In cases where homographic morphemes or word forms are central to the analysis, it is possible to disambiguate the functions of these morphemes/word forms using part-of-speech tagging (e.g., Weisser 2016, 101-20) and morphological tagging (e.g., Kübler and Zinsmeister 2015, 45-55). In this particular study, 'de' was the only affected morpheme salient to the discussion, and it was possible to circumvent the ambiguity by relying on other data; therefore, further analysis was not required. ${ }^{9}$ However, in the absence of more sophisticated segmenting tools, this issue could prove to be problematic with future corpus-based Japanese-language research where homographic morphemes are more central to the analysis.

\footnotetext{
7 For example, the word 'kudasai' (ください; 'please'), which does not require segmenting, was incorrectly segmented by the software and appeared as 'kuda sai' (ください) or ' $k u$ dasai' (ください). As this example shows, words that did not require segmentation were sometimes segmented by the software. To ensure consistency and the reliability of the data, incorrect segmentations were all manually corrected in the node corpus prior to the extraction of the subcorpora. 


\section{FINDINGS AND DISCUSSION}

\subsection{Keyword Analysis: Linguistic Repertoires of Humans and Bakenezumi}

Keyword analysis was applied to the BAKENEZUMI subcorpus with HUMANS as the reference corpus to determine the key linguistic features in the repertoire of Bakenezumi speech compared with human speech. By analysing linguistic differences based on the socio-demographic traits of each species, it was possible to determine the sociolect or linguistic code allocated to Squealer based on socio-demographic membership-that is, how Squealer does (and should) speak as a Bakenezumi in a world governed by humans.

Table 1: Keywords: BAKENEZUMI

Keywords in the BAKENEZUMI subcorpus with a minimum critical/keyness value of $15.13(\mathrm{p}<0.0001)$ and a minimum frequency of 5

\begin{tabular}{|c|c|c|}
\hline Keyness & Word/Morpheme & Meaning/Function \\
\hline 186.771 & ーません & negative polite suffix \\
\hline 180.995 & 神様 & $\operatorname{god}(\mathrm{s})$ \\
\hline 167.999 & です & polite form of だ \\
\hline 158.15 & ーます & polite suffix (non-past) \\
\hline 130.062 & 我々 & we (formal) \\
\hline 120.276 & ーまし- & polite suffix \\
\hline 104.929 & ござい-* & to be (polite) \\
\hline 92.299 & わたくしども & we (humble) \\
\hline 80.556 & お- & bikago prefix \\
\hline 76.564 & 女王 & queen \\
\hline 71.754 & コロニー & colony \\
\hline 65.405 & のです & 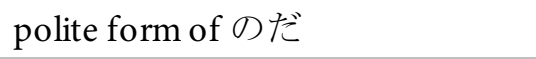 \\
\hline 62.931 & 我が & my, our (formal) \\
\hline 54.704 & よう & appearing..., looking..., a way of... \\
\hline 52.101 & あり- & to exist [inanimate], to have \\
\hline 46.267 & おり－ & to exist [animate] (humble) \\
\hline 42.769 & ご- & bikago prefix \\
\hline 39.342 & なり- & to become \\
\hline 38.669 & ので & because of..., given that... \\
\hline 35.961 & しかし & however \\
\hline 33.611 & は & topic marker \\
\hline 33.533 & どうか & somehow or other \\
\hline 30.158 & を & direct object marker \\
\hline 27.851 & いたし- & to do (humble) \\
\hline
\end{tabular}




\begin{tabular}{|c|c|c|}
\hline 27.32 & こちら & this way (formal) \\
\hline 27.182 & ーましょー† & polite tentative suffix \\
\hline 25.989 & 木冨蛾 & $\begin{array}{l}\text { name of a Bakenenezumi colony; also, } \\
\text { goat moth (Cossus cossus) }\end{array}$ \\
\hline 24.747 & など & et cetera \\
\hline 20.752 & ども & plural marker \\
\hline 20.631 & に & location/direction/indirect object marker \\
\hline 20.418 & 者 & thing \\
\hline 19.955 & ーば & if...then, when... \\
\hline 19.704 & 存在 & existence \\
\hline 19.693 & 地下 & underground \\
\hline 18.436 & が & subject marker \\
\hline 17.569 & で & time/location marker, variant of $\sim \tau$ \\
\hline 17.549 & 骨 & bone \\
\hline 17.125 & でし- & polite variant of だっ- \\
\hline 16.346 & 土蜘蛛 & $\begin{array}{l}\text { name of a Bakenenezumi colony; also a } \\
\text { species of spider (Atypus karschi) }\end{array}$ \\
\hline 15.832 & かしこまり- & to obey respectfully \\
\hline 15.519 & 二 & two \\
\hline
\end{tabular}

\section{Notes}

* The segmenting software parses 'gozaru' as a complete word, but splits all suffixes from the corresponding stems, such that 'gozaimasu' (ございます) becomes 'gozai-' (ござい-) and '-masu' (-ます), 'gozatta' (ござった) becomes 'goza(t)-' (ござっ-) and '-ta' (-た).

$\dagger$ The segmenting software also segments out the ' $u$ ' for all tentative forms, such that 'mashou' (ましょう) becomes 'masho' (ましょ-) and 'u' (-う), 'deshou' (でしょう) becomes 'desho' (でしょ-) and 'u' (-う).

From this keyword analysis (Table 1), several markers of honorific language can be seen, including teineigo (丁寧語; 'polite language' or addressee honorific language, e.g., 一ます, です, でしょう) and teichōgo (丁重語; 'courteous language' or humble language, e.g., おり-, いたし-). There are also a number of nonhonorific verbs in their stem form-for example, ‘かしこまり’ (to obey), ‘あり_' (to be/have) and ‘なり-’ (to become)—which can also flag the presence of addressee honorific language (see Figure 1). Additionally, there are a few markers of bikago (美化語; 'beautified language', e.g., お-, ご-), which can also be classified as honorific language in many instances (Jarkey 2015, 196-97). The particle 'o-' (お-) can also be a marker of sonkeigo (尊敬語; 'respectful language' or subject honorific language), since it is used as one of the affixes for productive subject honorific forms一for example, ‘お書きにな る' ('to write'). The relatively high keyness of these linguistic markers suggests that the linguistic repertoire of the Bakenezumi is characterised by honorific language. In the fictional world of the anime (hereafter, 'the text'), the high frequency of these honorific language markers is attributable to the power imbalance between the humans and the colonies of Bakenezumi to which Squealer belongs. 


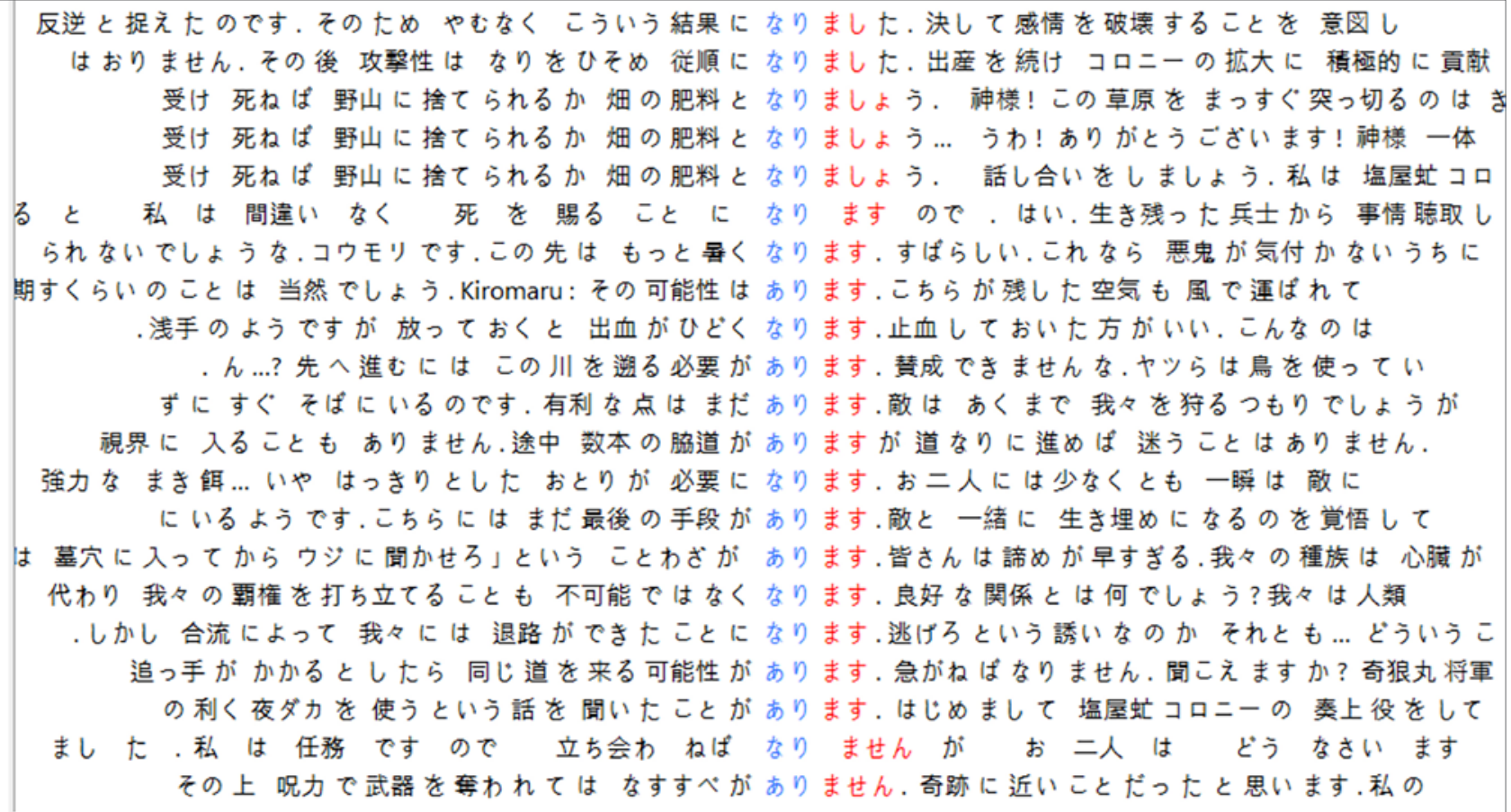

Figure 1: Concordance of ‘あり-’ and ‘なり-’ in the BAKENEZUMI subcorpus ${ }^{10}$

Given the relatively low social status of Squealer and the Bakenezumi species in the world of the text, the high frequency of honorific language markers reflects the typical use of honorific language, which is "to acknowledge and reinforce static social categories in a hierarchical system" (Jarkey 2015, 192). Honorific language is used when referring to or addressing individuals who are perceived as superiors in terms of age, seniority and social status, thereby indexing the hierarchical relationship of interlocutors as well as their relative power distance. This use of honorific language, therefore, indexes the relatively low social status of Bakenezumi in the world of the text.

Among the list of keywords, there are words that are concerned with selfreference-for example, 'ware ware' (我々; a formal variant of 'we') and 'waga' (我が; a formal variant of 'our')—or referencing/addressing others, for example 'kami-sama' (神梯; 'god(s)') or 'jo- $\vec{o}$ (女王; 'queen'). The keyness of the two words for referencing others conveys the socially conventional ways of addressing or referencing social superiors, which is influenced by the two power relationships experienced by the Bakenezumi. These terms also index the social position of the Bakenezumi in the fictional world of the text. The use of 'kami-sama' reinforces the relationship that the Bakenezumi have with humans. This term of address/reference elevates the status of humans while conveying the relatively low position of the Bakenezumi, reflecting a world order in which humans are dominant. Meanwhile, the use of ' $j o-\vec{o}$ ' as a term of reference creates another rung in the hierarchy between the humans and Bakenezumi, where one Bakenezumi (i.e., the queen) is elevated above the others, further lowering the social status of the general Bakenezumi populace. Overwhelmingly, self-referencing words used by the Bakenezumi are highly formal collective nouns or pronouns used to reference the speaker's 
in-group rather than the speaker themselves: for example, 'wareware' and 'watakushidomo' (わたくしども; humble form of 'we'). The collectivity of these expressions indexes the Bakenezumi's strong affiliation with their own ingroup, evident in the numerous ways in which they reference their colony and possibly their entire species-for example, 'waga koron’’ (我がコロニー; 'our colony' or 'our colonies').

In comparison, the keywords in the HUMANS subcorpus are characterised by markers of plain or casual language (e.g., だ, 一てる) and first names (e.g., Saki, Satoru, Mamoru) (see Table 2). These linguistic markers in the repertoire of the humans suggests that the humans regularly engage in conversations with those who are equal or lower in status to them, or those who are highly familiar to them. Additionally, the second-person pronoun 'anata' (あなた) appears as a keyword in the HUMANS subcorpus and is generally used as a term of address. Although its use can be either polite or informal depending on context (see Yonezawa 2014), the term seems to be avoided by the Bakenezumi, who prefer terms that explicitly convey power relationships, such as ' $k a m i$ sama' and ' jo- $\vec{o}$. The fact that the humans freely use 'anata', either despite or because of its hierarchical ambiguity, suggests that they are often in social contexts where they are not required to clearly recognise superiors, thereby indicating that humans themselves have a relatively superior social standing in the world of the text. Conversely, the fact that 'anata' did not emerge as a keyword for the Bakenezumi indicates that ambiguity around the observation of social hierarchy is less permissible, corroborating other indications that their social standing is lower than that of the humans. It should also be noted that the Bakenezumi do use 'anatagata' (あなたがた; formal variant of the secondperson plural) to address groups of humans. In this context, the addition of the formal humble plural suffix '-gata' (-がた) serves to align the pronoun with the other honorific forms of speech used by the Bakenezumi, supporting the interpretation that the Bakenezumi consciously eschew the singular form due to its hierarchical ambiguity. This further indexes the relatively low social status of Bakenezumi in the world of the text.

Table 2: Keywords: HUMANS

Keywords in the HUMANS subcorpus with a minimum critical/keyness value of 15.13 $(\mathrm{p}<0.0001)$

\begin{tabular}{|l|l|l|}
\hline Keyness & Word/Morpheme & English translation \\
\hline 110.089 & よ & emphatic sentence-final particle \\
\hline 71.653 & だ & be, is \\
\hline 57.261 & -てる & contraction of -ている \\
\hline 53.601 & ない & not..., not have/exist \\
\hline 44.128 & じゃ & then, well, so, casual form of では \\
\hline 41.093 & 早季 & Saki [name] \\
\hline 37.319 & ん & $\begin{array}{l}\text { variant of } \text { の, casual variant of negative } \\
\text { suffix }\end{array}$ \\
\hline 36.248 & うん & yes, uh huh, huh? \\
\hline
\end{tabular}




\begin{tabular}{|c|c|c|}
\hline 31.52 & って & variant of という \\
\hline 30.732 & んだ & non-polite variant of のです or んです \\
\hline 30.067 & ーたら & if...then, when, after \\
\hline 29.419 & わ & emphatic sentence-final particle (feminine) \\
\hline 26.501 & だっ- & variant of だ, non-polite variant of でし- \\
\hline 24.131 & なん & what \\
\hline 23.389 & あなた & you \\
\hline 22.327 & さん & $\begin{array}{l}\text { respectful honorific (occurs as a suffix with } \\
\text { names) }\end{array}$ \\
\hline 22.163 & 覚 & Satoru [name] \\
\hline 21.539 & 守 & Mamoru [name] \\
\hline 20.751 & ねえ & hey, come on, listen \\
\hline 20.751 & 僕 & I (masculine) \\
\hline 20.488 & 瞬 & Shun [name] \\
\hline 20.453 & だろ & $\begin{array}{l}\text { seems, I think, non-polite variant of } \\
\text { でしょ (colloquial) }\end{array}$ \\
\hline 19.361 & 何 & what \\
\hline 18.124 & けど & but, however \\
\hline 17.336 & ちょっと & a little, a bit, slightly \\
\hline 16.548 & 思う & to think, to feel \\
\hline 15.76 & 本当 & really \\
\hline 15.142 & 町 & town, city \\
\hline
\end{tabular}

Additionally, there are two types of linguistic markers that emerge as keywords in the linguistic repertoire of the humans, but are either highly infrequent or completely absent from the linguistic repertoire of the Bakenezumi. The first is ' $y o$ ' (よ), an emphatic sentence-final particle. While ' $y o$ ' does appear in the speech of Bakenezumi characters, its occurrence is highly infrequent (see Figure 2). Since ' $y o$ ' is associated with assertions in statements, its infrequency in Bakenezumi speech suggests that the Bakenezumi generally avoid making assertions when communicating with humans, in accordance with social protocols. By extrapolation, the Bakenezumi's avoidance of assertions can be interpreted as a strategy to appear polite or subservient towards their human interlocutors. Furthermore, Maynard (2001) argues that "the use and non-use of yo indexes how one wishes to express one's feelings and one's selves" (34). By limiting the use of ' $y o$ ', the Bakenezumi avoid showing their inner personae, which represent their thoughts and beliefs, while maintaining a subservient presentational persona that behaves according to social protocols established by the humans. 


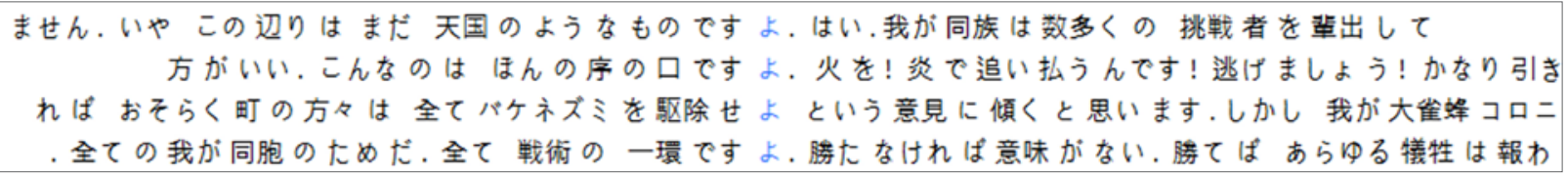

Figure 2: Concordance of ' 2 ' in the BAKENEZUMI subcorpus

The second type of linguistic marker that is highly frequent in the linguistic repertoire of the humans is gendered language, such as the masculine selfreference pronoun 'boku' (僕) and the feminine emphatic sentence-final particle ' $w a$ ' (わ). These markers allow speakers to express and assert their gender identity. The keyword analysis reveals that gendered language is common in the humans' speech. However, similar linguistic markers do not appear in the speech of the Bakenezumi, who instead rely on gender-neutral, plural self-reference terms such as 'ware ware' (我々; formal variant of 'we') and 'watakushidomo' (わたくしども; humble variant of 'we'), and generally avoid emphatic sentence-final particles, as discussed previously. This could be related to their strong association with their colonies and their general avoidance of any kind of linguistic markers that would otherwise represent them individually. The relatively high frequency of personal names in human speech compared with Bakenezumi speech also relates to this. Although the Bakenezumi possess their own personal names, these are rarely used by the Bakenezumi beyond the point of self-introduction and are quickly replaced by one of the collective first-person pronouns introduced above.

As this section has shown, a keyword analysis of dialogue can reveal linguistic patterns that are specific to socio-demographic groups in a telecinematic context, which in turn can offer insights into the language use of a focal character. The following section takes an in-depth look at the implications of Squealer's linguistic code when seen alongside those of other characters who feature in the narrative.

\subsection{Character-Based Analysis: Squealer's Default Linguistic Code}

Drawing on the findings of the repertoire analysis, Squealer's language use is examined in more detail through excerpts from selected scenes in order to establish the character's idiolect. Here, Bucholtz and Hall's (2005) framework is used to discuss the indexicality of the use and non-use of certain linguistic items or patterns, as well as the potential indexicality of deviating from the established sociolect. The focus of the discussion is on how the use and non-use of these linguistic features index certain aspects of Squealer's identity.

As a Bakenezumi, Squealer's idiolect contains a number of linguistic features that are also present in the Bakenezumi sociolect, such as the markers of honorific language. However, while the use of honorific language indexes Squealer's relatively low social status in a world governed by humans, the high frequency of markers for honorific language in comparison with their 
frequency in the dialogue of other Bakenezumi also indexes Squealer's demeanour (see Table 3). Squealer's typical speech patterns (until the final episode of the series) are illustrated in Excerpt 1, below.

Table 3: Raw frequencies of honorific language markers (comparing Squealer and other Bakenezumi)

\begin{tabular}{|c|c|c|c|c|}
\hline Word/Morpheme & Lemmas* in the subtitles & Meaning/Function & Freq. (Squealer) & Freq. (Others) \\
\hline ーます & -ません，-まし-，一ましょ- & polite verbal suffix & 170 & 127 \\
\hline です & でしょ-, でし- & be, is, polite variant of だ & 74 & 102 \\
\hline お- & & bikago prefix & 45 & 17 \\
\hline ござい- & & to be (super-polite) & 34 & 4 \\
\hline のです & のでしょ-, んでしょ-, んです & 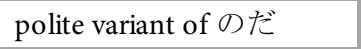 & 22 & 23 \\
\hline ご- & & bikago prefix & 19 & 5 \\
\hline おり- & & to be, exist (humble) & 19 & 3 \\
\hline ください & & please do (respectful) & 11 & 6 \\
\hline いたし- & 致し- & to do (humble) & 8 & 2 \\
\hline いただく & $\begin{array}{l}\text { いただける, いただか-, いただき-, } \\
\text { いただけ-, いただけれ-, 頂い-, } \\
\text { 頂き-, 頂く }\end{array}$ & $\begin{array}{l}\text { to receive, eat, drink } \\
\text { (humble) }\end{array}$ & 8 & 4 \\
\hline 申し上げる & 申し上げ- & to say, tell (humble) & 4 & 1 \\
\hline なさる & なさい-, なさら-, なさっ- & to do (respectful) & 3 & 2 \\
\hline 参り- & まいり- & to come, go (humble) & 3 & 1 \\
\hline 存じ- & & to know, think (humble) & 3 & 0 \\
\hline 申し- & & to say (humble) & 3 & 0 \\
\hline ご覧- & & to look, see (respectful) & 2 & 0 \\
\hline いらっしゃる & いらっしやい- & to come, go, be (respectful) & 2 & 0 \\
\hline おっしやる & & to say, speak (respectful) & 1 & 0 \\
\hline 申し開き & & excuse (humble) & 1 & 0 \\
\hline
\end{tabular}

\section{Notes}

${ }^{\star}$ Inflectional or orthographical variations of a wordform or morpheme

In this excerpt, Saki (the protagonist) and her friend Satoru become reacquainted with Squealer, whom they have not seen for two years. Here, Squealer uses an elaborate combination of honorific language, including teineigo (addressee honorifics, bolded in lines 1, 3, 6, 7 and 9), sonkeigo (subject honorifics, underlined in line 1), kenjōgo (謙䜇語; object honorifics, underlined in line 5) and teichōgo (humble language, underlined in line 9). This combination of multiple honorific language types, along with the term of address ' $k a m i$-sama' (underlined in lines 3 and 5), communicates a deferential attitude towards the humans as social superiors (i.e., as 'gods'). In the following excerpts, usage of the different types of honorific language is indicated with corresponding acronyms and the '+' symbol, while the absence of any type of honorific language is indicated by '-HON'.

\section{Excerpt (1) ${ }^{11}$}

1 Squealer: お目覚めになられたようですね。

"It looks(+AH) like you have regained(+SH) consciousness." 
Squealer: お久しぶりでございます、神様。

"It has been(+SP, +AH) a long time, gods."

Saki:

本当ね。スクイーラは元気にしてたの?

"It really has. Have you been doing well, Squealer?"

Squealer:

はい。最近は神様にご奉仕させていただく機会も多く なりましてありがたいことに大変名誉ある名前まで 賜りました。

"Yes. Lately the opportunity to be of service $(+\mathrm{OH})$ to my gods has been $(+\mathbf{A H})$ plentiful, that I was honoured to have a most noble name bestowed(+AH) upon me."

Saki:

どんな名前?

"What kind of name is it?"

Squealer: はい! 野狐丸と申します！

"Right. I am(+HL, +AH) (now) Yakomaru!"

(from Episode 15, “Afterimage”)

In line 3, Squealer uses the super-polite 'degozaru' (in bold), in combination with the honorific suffix '-masu', as 'degozaimasu' (でございます). Additionally, Squealer uses a particularly polite grammatical construction (bolded in line 6). Here, the linking suffix '-te' is affixed to the polite suffix '-masu', resulting in the polite conjunctive form (i.e., なりまして) of the word 'naru' (なる; 'to become')-even though the plain conjunctive 'natte' (なって) is acceptable in honorific speech. By using this form, Squealer's normally high level of honorific language is effectively increased.

Based on this wide variety of honorific language markers, it can be inferred that Squealer's use of honorific language, in addition to expressing and acknowledging social status or hierarchical relationships (discussed in 4.1), may also relate to Goffman's (1956) notion of demeanour. Goffman describes demeanour as being "conveyed through deportment, dress, and bearing" in order "to express to those in [one's] immediate presence that [one] is a person of certain desirable or undesirable qualities" $(1956,489)$. The appropriate use of honorific language can therefore convey a refined demeanour, since it implies strong understanding and mastery of social protocols relating to language use.

Relating to the use of honorific language to express politeness and demeanour, Hasegawa (2006) further relates politeness to the idea of "prudence" and argues that it is "linked to social class and socio-political power" (211). Thus, mastery over the use of honorifics is likely to signal membership of a high social class, as well as an overall "high degree of mental cultivation, elegant refinement, 
polished manner, and good taste" (Hasegawa 2006, 211). Therefore, while frequent honorific use indexes a low social standing, it also paradoxically indexes cultivation and refinement. Furthermore, Squealer's interlocutors rarely reciprocate a comparable level of honorific use, resulting in consistent juxtaposition of Squealer's honorifics with the less polite or refined speech of others. This calls attention to Squealer as possessing a particularly refined demeanour and suggests a degree of social superiority over other Bakenezumi and humans.

As shown here, a character-based analysis can build on a keyword analysis to reveal a focal character's repeated and salient linguistic patterns (i.e., the character's idiolect), which gives further insight into aspects of that character. As a Bakenezumi, Squealer uses language patterns strongly associated with the species, which demonstrates the character's social membership and relative social rank in the fictional world of the text. However, some aspects of the character's personal traits can be inferred from the overuse of honorific markers-most notably, the apparent desire to present a refined persona. The following section examines a key scene in which Squealer deviates from the established idiolect or character-specific linguistic code, and explores the potential social meanings that this entails.

\subsection{Scene-Based Analysis: Speech Style Shifts and Squealer's Other Persona}

The character-based analysis provides a general overview of Squealer's character and salient characteristics. However, as Bucholtz and Hall point out, identity is not static nor a fixed construct but "a discursive construct that emerges in interaction" $(2005,587)$. To address this point, the following analysis of one key scene demonstrates how different aspects of Squealer's identity emerge in unfolding interactions, and which linguistic forms index these aspects of the character's identity. Despite the prevalence of honorific language markers in Squealer's dialogue, it is important to note that these markers are not always used consistently, even within a single conversation or interaction. In the final episode, Squealer begins to use non-honorific language for the first time in the series, which is highly uncharacteristic given the character's idiolect. This section examines a scene in which Squealer shifts between using and not using honorific language. Drawing excerpts from a conversation between Squealer, Saki and Satoru, this scene-based analysis examines how different aspects of Squealer's character are foregrounded by adherence to or deviation from the speech patterns established over the preceding episodes.

The conversation from which the following two excerpts derive involves Saki and Satoru visiting Squealer, who has been imprisoned for leadership in a revolt against the human society. In this scene, Saki and Satoru attempt to elicit Squealer's motives for the revolt, which resulted in a massacre of humans. Excerpt 2 begins following a comment by Squealer about the volatile co-existence of the Bakenezumi and the humans, where the humans would occasionally eliminate large numbers of Bakenezumi. In response, Saki 
explains that the massacre of Bakenezumi is a heavy punishment which is used as a final resort towards incriminated Bakenezumi and their colonies. She implies that if Squealer had not initiated a revolt, deaths of both humans and the Bakenezumi species could have been avoided.

\section{Excerpt (2) ${ }^{12}$ \\ 1 Saki: \\ 2 \\ 3}

5

6

7

8

9
コロニーの抹消はいちばん重い処分よ。よほどのこと がなければないわ。それこそ人間を殺傷したり反逆を 企てたりしなければ...

"The eradication of a colony incurs the heaviest punishment. It is reserved for the gravest offences. If you hadn't killed human beings, or revolted against us, then..."

Squealer: 鶏が先か、卵が先か…いずれにせよ、我々はよどみ に浮かぶうたかたのような立場です。そこから脱した いと願うのは当然のことではないですか?我々は高度 な知性を持った存在です。あなた方と比べても何ら劣 るところはない。違いと言えば呪力という悪魔の力を 持つか否かだけだ。

"[Which came(-HON) first,] the chicken or the egg...? Either way, we are $(+\mathbf{A H})$ like bubbles on the surface of a pond. Is $(+\mathbf{A H})$ it not natural to wish to escape that fate? We are $(+\mathbf{A H})$ beings who possess high intelligence. We are not(-HON) inferior to you in any way. The only difference is(-HON) that you possess the demonic power called 'Juryoku', and we do not."

(from Episode 25, "From the New World")

Responding to Saki's comments, Squealer employs the non-polite style to ask the rhetorical question: ‘鶏が先か、卵が先か...' ('Which came first, the chicken or the egg?'; line 4). However, following this, Squealer returns briefly to more typical honorific language and polite speech style (bolded in lines 5, 6 and 7). In the context of a criticism of humans, Squealer shifts into the non-polite style (double-underlined in lines 4, 8 and 9). Based on this, the subservient demeanour indicated by Squealer's typical use of honorifics can be seen as a façade which breaks down when his true thoughts emerge. This suggests that Squealer is simply acting out a public persona that the humans ascribe to members of the Bakenezumi species.

This is emblematic of the broader conversation from which Excerpt 2 is taken, where Squealer similarly shifts between polite/honorific and nonpolite styles. It is likely that these shifts index the switch between a Japanese speaker's 'innate' self and the social persona they choose to present (e.g., Cook 2008; Yamaji 2008). According to Cook, the polite style indexes public self-presentation, whereas the non-polite style foregrounds the "innate self" $(2008,15)$. Cook goes on to suggest that these differences in self-presentation further index different social personae. When using the polite style, a speaker 
is literally or figuratively acting "on-stage" and is showing their presentational persona or professional self (Cook 2008, 15). On the other hand, a speaker is acting naturally or spontaneously when using the non-polite style, which indexes their private or innate self. The explicitness of the criticisms in Squealer's non-polite speech aligns with the idea that the non-polite speech style is actually the one that indexes the character's true persona (i.e., one that resents the humans).

Excerpt 3 below is from the same conversation as Excerpt 2 and forms the latter half of the overall scene. In this excerpt, Squealer is mainly responding to accusations and comments made by Satoru. This example shows the gradual breakdown of Squealer's established presentational persona, represented by the polite speech style, and the emergence of a previously repressed inner persona, represented by the non-polite or plain speech style.

\section{Excerpt (3)}

1 Satoru:

お前はコロニーのためのようなことを言ってるけど 奇狼丸は違う意見だった。女王の権力をさん篡奪して あんまりな扱いをしたことはどう正当化するんだ?

"You say that you acted for the good of your colony, but Kirōmaru thought differently. How do you justify the dethroning of your queens and how you treated them afterwards?"

4

5

6

$7 \quad$ Satoru:

8

9

Satoru:

11 Squealer:

12 Satoru:

Squealer: 奇狼丸は旧弊な思想に凝り固まった爺いで本質が全 く見えていなかった。実権を女王が握っている限り 改革など不可能だということを。

"Kirōmaru was an old geezer who was obsessed with antiquated ways of thinking and could not see(-HON) the truth at all. As long as the queens held power, reform was not possible."

奇狼丸は改革など望んでいなかった。

"Kirōmaru did not desire reform."

$$
\begin{aligned}
& \text { Squealer: 私が改革をもたらそうとしたのは自分のコロニーのた } \\
& \text { めではない。 } \\
& \text { "I } \underline{\underline{\text { didn't(-HON) }}} \text { enact reform for the sake of my own }
\end{aligned}
$$

お前の醜い権力欲を満たすためか?

"Was it to satiate your own despicable lust for power?"
全ての我が同胞のためだ。

"It was(-HON) for the sake of my brethren."

調子のいいこと言うな!お前は自分の兵士を平気で捨 て駒にしたじやないか?!

“That's rich coming from you! Didn't you use your own soldiers as sacrifices without batting an eyelid?!"

t


"It was(+AH) all part of the strategy. Only victory has(-HON) meaning. If we'd won, then all of the sacrifices would have been rewarded(-HON)."

Satoru:

お前は負けたんだ。

"But you lost."

Squealer:

\begin{tabular}{l} 
そう…私が万死に值するのはこの一点です。メシア \\
\hline という絶対的な切り札を得ながら単純なトリックに
\end{tabular} ひっかかり全てを失ってしまった。歴史を変えられる はずだった。これほどの好機はおそらくもう二度と訪 れない。 "Yes(-HON)...That is(+AH) why I deserve to die. I held the ultimate trump card, the Messiah, but lost($\underline{\underline{H O N})}$ everything to a simple trick. I could have changed(-HON) history. An opportunity like this may never come(-HON) again."

Satoru:

行こう。これ以上話したって時間の無駄だ。

"Let's go. It's a waste of time to talk any further."

(From Episode 25, "From the New World")

Here, Squealer speaks primarily using the non-polite or plain style (doubleunderlined), briefly returning to the polite style in lines 14,17 and 21 (in bold). These final flashes of politeness can be interpreted as the gradual breakdown of Squealer's established public persona. In comparison, the increasing use of the plain style marks the gradual shift to dominance of Squealer's true persona, reflected by the character's increasingly candid speech. One explanation for this is that Squealer, as a representative of a socially repressed society with much at stake, realises that the only remaining chance for the Bakenezumi is to speak frankly, perhaps in an attempt to gain the humans' understanding. As such, the fact that Squealer is speaking predominantly in the plain style suggests that the socially repressed inner persona is gradually achieving prominence over the presentational persona at an emotionally charged point in the narrative.

In the scene examined above, uncharacteristic language is used as a device to highlight a character's inner persona, which in turn is used to candidly reveal thoughts and opinions hitherto hidden from interlocutors. The scenebased analysis demonstrates that (character) identity is not static nor a fixed construct but "a discursive construct that emerges in interaction" (Bucholtz and Hall 2005, 587). It also demonstrates how a character's deviation from an established idiolect can allow different aspects of that character's identity to emerge in unfolding interactions. Taken in its entirety, this section has shown that a corpus-based mixed-method approach to telecinematic texts can offer a highly nuanced level of insight into the identity construction of characters through language. 


\section{CONCLUSION}

This study has examined how language is used to construct the non-human character Squealer in the anime series, From the New World. Drawing primarily on the notions of the indexicality principle and corpus linguistic methodologies, it shows that salient aspects of a character's identity can be understood from the character's established linguistic repertoire, including (but not limited to) strong in-group affiliation, low social status and overall presentation of subserviency. Additionally, the scene-based analysis demonstrates how shifts between use and non-use of certain linguistic features help to foreground different stances and personae. This study demonstrates that insights about the discursive construction of telecinematic characters can be gained by integrating corpus linguistic analysis with scene-based analysis, drawing on sociolinguistic concepts.

A number of issues were encountered when using corpus programs for the segmentation and analysis of Japanese linguistic data in this study, despite the fact that the programs used were designed to be compatible with Japanese linguistic data. In future studies of this nature, meticulous effort will be needed to limit inconsistencies (as with this study, which required manual correction of large volumes of data due to software limitations) or more appropriate software will need to be developed. These issues notwithstanding, this study has demonstrated that corpus linguistics can be used effectively in a mixed-method approach to examine characterisation. In doing so, it has contributed to the emerging area of corpus linguistics in Japanese linguistic research as well as the still under-represented area of Japanese telecinematic discourse studies.

\section{GLOSSARY}

bikago (美化語) lit., 'beautified language'. Also known as 'word beautification'. Bikago often involves adding the prefixes お- or ご- to nouns. The main function of these forms is to make words more polite or more aesthetically pleasing ('beautiful'), which leads to the speaker being perceived as having an elegant or refined manner of speech.

kenjōgo (謙譲語) lit., 'modest language'. Also known as 'object honorific language'. It is generally used when speakers talk about their own actions or the actions of their in-group members that are related to a person with higher social status (e.g., doing something for someone, helping someone with something). The main function of object honorific language is to show respect to the recipient of the action (i.e., the object of a transitive or ditransitive verb) while humbling the initiator of the action.

sonkeigo (尊敬語) lit., 'respectful language'. Also known as 'subject honorific language'. It is typically used when speaking about the actions of a referent who is older or higher in status. 
teineigo (丁寧語)

teichōgo (丁重語)

yakuwarigo (役割語) lit., 'polite language'. Also known as 'addressee honorific language'. It is normally used when the speaker considers the addressee psychologically distant, and/or the speaker wishes to honour or show respect to the addressee. This type of honorific language is generally characterised by sentences ending with conjugations of the copula 'です' and conjugations of the predicate suffix ‘ーます’.

lit., 'courteous language'. Also known as 'humble forms' or 'humble language'. These forms neither show explicit respect to the referents nor the addressee, but mainly serve to humble the actions of the speaker.

lit., 'role language'. A term coined by Kinsui (2003) which refers to the spoken linguistic (e.g., vocabulary and grammar) and phonetic (e.g., intonation patterns and accents) features that are strongly associated with particular character archetypes.

\section{ANIME REFERENCES}

Ishihama, M. [石浜 真史] (dir). Shinsekai Yori [新世界より]. 2012-13; Tokyo: TV Asahi. Television series.

Kaburagi, H. [鏑木 ひろ] (dir). Kimi ni Todoke [君に届け]. 2009-10; Tokyo: NTV. Television series.

Nagai, T. [長井 龍雪] (dir). Toradora! [とらドラ!]. 2008-9; Tokyo: TV Tokyo. Television series.

Watanabe, S. [渡辺 信一郎] (dir). Cowboy Bebop [カウボーイビバップ]. 1998-99; Tokyo: TV Tokyo. Television series.

\section{REFERENCES}

Abe, S. 2016. "An L2 Corpus Study of the Japanese Grammatical Marker -te-simau: An Application of Force Dynamics". In Cognitive-Functional Approaches to the Study of Japanese as a Second Language, edited by K. Kabata and K. Toritani, 203-36. Berlin: Mouton de Gruyter. https://doi.org/10.1515/ 9781614515029-011/.

Androutsopoulos, J. 2012. "Repertoires, Characters and Scenes: Sociolinguistic Difference in Turkish-German Comedy." Multilingua 31: 301-26. https:// doi.org/10.1515/multi-2012-0014/.

Anthony, L. 2009. "Issues in the Design and Development of Software Tools for Corpus Studies: The Case for Collaboration”. In Contemporary Corpus Linguistics, edited by P. Baker, 87-104. London \& New York: Continuum.

. 2016. "AntConc (Version 3.4.4)" [computer software]. Tokyo, Japan: Waseda University. Available from http://www.laurenceanthony.net/ 
Armour, W. S. and S. Iida. 2014. "Are Australian Fans of Anime and Manga Motivated to Learn Japanese Language?” Asia Pacific Journal of Education 36 (1): 3147. https://doi.org/10.1080/02188791.2014.922459/.

Baker, P. 2006. Using Corpora in Discourse Analysis. London \& New York: Continuum.

Bednarek, M. 2011. "The Stability of the Televisual Character: A Corpus Stylistic Case Study". In Telecinematic Discourse: Approaches to the Language of Film and Television Series, edited by R. Piazza, M. Bednarek \& F. Rossi, 185-204. Amsterdam/Philadelphia: John Benjamins Publishing Company. https://doi.org/10.1075/pbns.211.13bed/.

. 2012. "Constructing 'Nerdiness': Characterisation in The Big Bang Theory". Multilingua 31: 199-229.

Benešová, M. and D. Birjukov. 2015. "Application of the Menzerath-Altmann Law to Contemporary Written Japanese in the Short Story Style." In Recent Contributions to Quantitative Linguistics, edited by A. Tuzzi, M. Benešová and J. Macutek, 13-25. Berlin: Mouton de Gruyter. https://doi. org/10.1515/9783110420296-003/.

Bucholtz, M. and K. Hall. 2005. "Identity and Interaction: A Sociocultural Linguistic Approach.” Discourse Studies 7 (4/5): 585-614. https://doi. org/10.1177/1461445605054407/.

Cook, H. M. 2008. "Style Shifts in Japanese Academic Consultations." In Style Shifting in Japanese, edited by K. Jones and T. Ono, 9-38. Amsterdam/ Philadelphia: John Benjamins Publishing Company. https:/doi.org/10.1075/ pbns.180.00sty/.

Den, Y. n.d. Challenges in Japanese Corpus Linguistics. Accessed 15 October, 2017. http://www.chiba-u.ac.jp/e/research/distinctive/files/den.pdf.

Fennell, D., A. S. Q. Liberato, B. Hayden and Y. Fujino. 2012. "Consuming Anime." Special Section: TV and New Media Audiences 14 (5): 440-56.

Fujimura, I., S. Chiba and M. Ohso. 2012. "Lexical and Grammatical Features of Spoken and Written Japanese in Contrast: Exploring a Lexical Profiling Approach to Comparing Spoken and Written Corpora." Proceedings of the VII $^{\text {th }}$ GSCP International Conference. Speech and Corpora: 393-98.

Goffman, I. 1956. “The Nature of Deference and Demeanor." American Anthropologist 58: 473-502. https://doi.org/10.1525/aa.1956.58.3.02a00070/.

Gumperz, J. J. 1964. "Linguistic and Social Interaction in Two Communities." American Anthropologist 66 (6/2): 137-53.

Hasegawa, Y. 2006. "Embedded Soliloquy and Affective Stances in Japanese." In Emotive Communication in Japanese, edited by S. Suzuki, 209-29. Amsterdam/Philadelphia: John Benjamins Publishing Company. https:// doi.org/10.1075/pbns.151.11has/. 
Hiramoto, M. 2013. "Hey, You're A Girl? Gendered Expressions in the Popular Japanese Anime, Cowboy Bebop." Multilingua 32 (1): 51-78. https://doi. org/10.1515/multi-2013-0003/.

Hollis, L. 2014. "Anime and the Real World Gendered Use of Sentence Final Particles across Genres." Griffith Working Papers in Pragmatics and Intercultural Communication 6: 20-27.

Jarkey, N. 2015. "The Housewife's Companion: Identity Construction in a Japanese Women's Magazine." In Language and Identity Across Modes of Communication, edited by D. N. Djenar, A. Mahboob and K. Cruickshank, 179-201. Berlin: Mouton de Gruyter. https://doi.org/10.1515/9781614 $513599.179 /$.

Kinsui, S. [ [金水 敏]. 2000. Yakuwarigo tankyū no teian [役割語探求の提案]. In 'Kokugo-shi no shin-shiten' Kokugo Ronkyū, dai hachi shū [『国語史の新視 点』国語論究、第8集], edited by K. Sato, 311-35. Tokyo, Japan: Meiji Shoin [明治書院].

2003. Vācharu Nihongo: Yakuwarigo no Nazo [ヴァーチャル日本語 役割語の 謎]. Tokyo, Japan: Iwanami Shoten [岩波書店].

Kübler, S. and H. Zinsmeister. 2015. Corpus Linguistics and Linguistically Annotated Corpora. London: Bloomsbury Academic.

Lee, H.-K. 2011. "Participatory Media Fandom: A Case Study of Anime Fansubbing." Media, Culture and Society 33 (8): 1131-47. https://doi.org/10.1177/ 0163443711418271/.

Lee, J.-H. and N. Nakagawa. 2016. "KY Corpus." In Handbook of Japanese Applied Linguistics, edited by M. Minami, 255-82. Berlin: Mouton de Gruyter. https://doi.org/10.1515/9781614511830-015/.

Maekawa, K. 2015. “Corpus-Based Phonetics." In Handbook of Japanese Phonetics and Phonology, edited by H. Kubozono, 651-80. Berlin: Mouton de Gruyter. https://doi.org/10.1515/9781614511984.651/.

Mandala, S. 2011. "Star Trek: Voyager's Seven of Nine: A Case Study of Language and Character in a Televisual Text." In Telecinematic Discourse: Approaches to the Language of Film and Television Series, edited by R. Piazza, M. Bednarek \& F. Rossi, 205-223. Amsterdam/Philadelphia: John Benjamins Publishing Company. https://doi.org/10.1075/pbns.211.14man/.

Maynard, S. K. 2001. "Falling in Love with Style: Expressive Functions of Stylistic Shifts in a Japanese Television Drama Series." Functions of Language 8 (1): 1-39. https://doi.org/10.1075/fol.8.1.02may/.

Miyata, S. and B. MacWhinney. 2016. "CHILDES for Japanese: Corpora, Programs, Perspectives." In Handbook of Japanese Applied Linguistics, edited by M. Minami, 283-312. Berlin: Mouton de Gruyter. https://doi.org/10.1515/ 9781614511830-014/. 
Piazza, R., M. Bednarek and F. Rossi, eds. (2011). Telecinematic Discourse: Approaches to the Language of Films and Television Series. Amsterdam/Philadelphia: John Benjamins Publishing Company. https://doi.org/10.1075/pbns.211/.

Queen, R. 2015. Vox Popular: The Surprising Life of Language in the Media. Oxford/ Malden: Wiley-Blackwell.

Richardson, K. 2010. Television Dramatic Dialogue: A Sociolinguistic Study. Oxford: Oxford University Press. https://doi.org/10.1093/acprof:oso/9780195374056. 001.0001/.

. 2017. "Dialogue and Character in 21st Century TV Drama: The Case of 'Sherlock Holmes'." In Dialogue Across Media, edited by J. Mildorf and B. Thomas, 39-70. Amsterdam/Philadelphia: John Benjamins Publishing Company. https://doi.org/10.1075/ds.28/.

Saito, K. 2014. "Magic, Shōjo, and Metamorphosis: Magical Girl Anime and the Challenges of Changing Gender Identities in Japanese Society." The Journal of Asian Studies 73 (1): 143-64. https://doi.org/10.1017/S0021911813001708/.

Scott, M. \& C. Tribble. 2006. Textual Patterns: Key Words and Corpus Analysis in Language Education. Amsterdam/Philadelphia: John Benjamins Publishing Company. https://doi.org/10.1075/scl.22/.

Siegel, M., E. M. Bender and F. Bond. 2016. Jacy: An Implemented Grammar of Japanese. Stanford: CSLI Publications/Center for the Study of Language \& Information.

Toh, W. 2014. “A Multimodal Framework for Tracking Sesshomaru’s Character Development in an Anime Movie-Inuyasha: Swords of an Honourable Ruler-An Appraisal and Gestural Perspective." Social Semiotics 24 (1): 124-51. https://doi.org/10.1080/10350330.2013.833722/.

Vignozzi, G. 2016. "How Idiomatic are Disney Animated Films? The Multimodal Meaning-Making of Idioms." In Multimodality Across Communicative Settings, Discourse Domains and Genres, edited by V. Bonsignori and B. C. Camiciottoli, 236-64. Newcastle-upon-Tyne: Cambridge Scholars Publishing.

Weisser, M. 2016. Practical Corpus Linguistics: An Introduction to Corpus-Based Language Analysis. Oxford/Malden: Wiley-Blackwell. https://doi.org/10. 1002/9781119180180/.

Yamaji, H. 2008. "Manipulation of Honorifics in First-Encounter Conversations in Japanese." PhD dissertation, The University of Arizona, Tucson.

Yonezawa, Y. 2014. 'Nininshō daimeishi 'anata' ni kansuru ichikōsatsu: Kokkaigijiroku no bunseki o tōshite” [二人称代名詞「あなた」に関する一考 察：国会議事録の分析を通して]. Proceedings of the 18th Biennial Conference of the Japanese Studies Association of Australia. http://japaninstitute.anu. edu.au/sites/default/files/u6/26_Yoko_Yonezawa-JSAA2013.pdf. 


\section{Straddling the Line: How}

Female Authors are Pushing the Boundaries of Gender Representation in Japanese Shōnen Manga
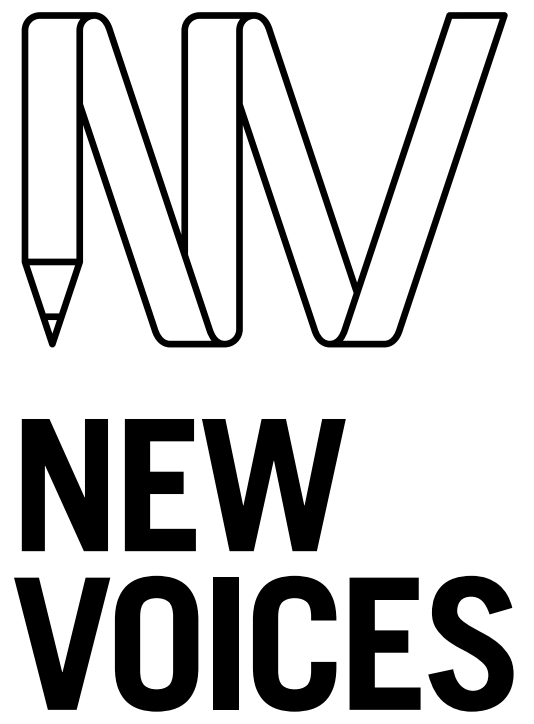

IN JAPANESE STUDIES

\section{DANIEL FLIS}

Murdoch University

\section{ABSTRACT}

This paper will show the ways in which authors of shonen (boys') manga can offer representations of gender performance that depart notably and significantly from the conventional framework which characterises many shōnen manga works (the 'shonen framework'). It does this through a comparative analysis of gender performance in two shōnen manga series: Noragami [2010-], by female author duo Adachitoka, and Akame ga Kill! [2010-16], by male authors Takahiro and Tetsuya Tashiro. The paper seeks to demonstrate how the authors of Noragami have been able to subvert the gendered framework of shonen manga while still writing within the genre. Examples of non-conventional gender performance in the femaleauthored work include resistance to gendered power dynamics and parody of traditional gender roles. These departures do not always reject the shonen framework altogether, but instead present new ways for gender performance to be represented within it. In straddling the line between conforming to and subverting shonen tropes, Noragami shows the potential for texts to shape and contest ideas about gender identity within a genre that is still dominated by hegemonic masculinity.

\section{KEYWORDS}

contemporary; femininity; gender; genre; hegemonic masculinity; manga; parody; popular culture; representation; shōnen; stereotypes; women

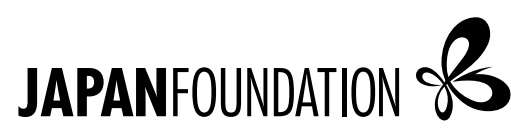

BRINGING JAPAN TO YOU

To link to this article: https://doi.org/10.21159/nvjs.10.04

\section{ISSN 2205-3166}

New Voices in Japanese Studies is an interdisciplinary, peer-reviewed journal showcasing the work of emerging scholars from Australia and New Zealand with research interests in Japan.

All articles can be downloaded free at newvoices.org.au

(c) The Japan Foundation, Sydney and Daniel Flis, 2018

\section{(c) $(i)(8)$}

This work is licensed under a Creative Commons Attribution-NonCommercialNoDerivatives 4.0 International License. 


\section{INTRODUCTION}

This paper is interested in the intersection of gender and popular culture in Japan, and specifically, representations of gender in Japanese manga. In this discussion I demonstrate how two female authors of contemporary shōnen (少年; boys') manga have been able to portray representations of gender which are non-conventional in the genre while still remaining successful in the market. To show how this is achieved, I will analyse and compare the images and language of two shōnen manga texts with similar target readerships. Firstly, I will examine the male-authored shōnen manga series Akame ga Kill! (アカメが斬る! ['Akame Kills!']; 2010-2016) as an example of how shōnen manga is written when conforming to the commonly used framework for gender performance in the genre (the 'shōnen framework'). ${ }^{1}$ Secondly, I will analyse the female-authored shōnen manga series Noragami (ノラガミ; 2010-) to reveal how it straddles the line between conforming to and subverting the shōnen framework, thus opening up new ways for gender to be represented in this context.

Japanese manga has seen a surge in global popularity in recent years (Alverson 2017). It would be unusual to enter a Western comic book store in 2018 and not find a dedicated 'Japanese manga' section showcasing a diverse range of titles. In Japan, manga is marketed and sold in four distinct genres: shōnen (boys'), shōjo (少女; girls'), seinen (青年; young men's) and josei (女性; women’s) manga (Matanle et al. 2014, 475). These genres are named to correspond with the assumed gender and age of their target readers, and the characters represented within "are likely to reflect the characteristics of the desired readership" (Ueno $2006,16)$. This has given form to a framework which influences the way gender is commonly represented within each genre. For example, the shōnen manga genre is so named because it is targeted at boys in their late teens; as such, its content is commonly intended to appeal to boys at an age where they typically undergo puberty and develop romantic and sexual interests (Jones 2013). Shōnen manga often offers up simplistic heteronormative narratives centring on a male protagonist who "goes through multiple trials and setbacks as he ventures on to a bright and glorious future" (Ingulsrud and Allen 2010, 13). The gendered framework in shonen manga ensures that the male protagonist exemplifies 'hegemonic masculinity' as understood by R. W. Connell (2005): he acts in ways which legitimise the dominant position of men in society and justify the subordination of women. ${ }^{2}$ On the other hand, female characters in this genre are relegated to supporting roles and/or sexualised (Ito 2000, 10-11).

Until the 1990s, there were very few shōnen manga series written by women. However, over the last few decades, female authors of shonen manga have become more common and their works often reach a mainstream audience. Popular examples include Rumiko Takahashi’s Inuyasha (犬夜叉; 19962008), Hiromu Arakawa's Fullmetal Alchemist (鋼の錬金術師; 2001-2010) and Shinobu Ōtaka's Magi (マギ; 2009-2017). During this time, the female

1 The official title in Japanese is read as 'Akame ga Kiru!', but the series' tankōbon (単行本; 'stand-alone book'; non-serial manga) publications officially romanise the title as 'Akame ga Kill!', which I adopt here for simplicity. 
readership of shōnen manga has also been on the rise ("Hakkō busū" 2012). This paper is interested in the phenomena of female authors writing popular works for a genre which is targeted primarily at young males, and how these authors can challenge perspectives rooted in hegemonic masculinity. While challenges to stereotypical gender representations can come from any author, regardless of their gender, this paper draws inspiration from feminist standpoint theory which holds that "only women's perspective[s] can open up epistemic space to radically reorganise the gendered relations of domination in society" (Cattien 2017, 8). From this position, I argue that female authors writing in the shōnen genre are more likely to critique or subvert the dominant gendered framework than male authors. ${ }^{3}$ My aim is to explore one example of how female-authored shonen manga has been able to loosen the genre's rigid gender framework and create spaces within it which allow for a greater variety of gender performances.

\section{THE SHŌNEN FRAMEWORK}

Manga with a male target readership, including shōnen and seinen manga, has long been criticised for its exploitative and oppressive representations of women. One of the earliest comprehensive studies of gender representations in shōnen manga was Kinko Ito's (1994) analysis of thirty-one weekly shōnen manga comics from 1990 to 1991. Ito found that, in most stories, the female characters are bystanders-if they exist at all. Anne Allison (1996) remarks that "sexuality is heavily imbricated with violence in Japanese comics" (71), and Susan Napier (1998) criticises the depiction of women and girls in manga as representing negative stereotypes. While these criticisms date back to the 1990s, when English-language manga scholarship was first emerging, they still apply today. In a 2013 study of four twenty-first century shōnen manga series, Hattie Jones finds that shōnen manga still "reflect[s] a lack of understanding about the [female] sex" (73). These representations of female characters are evidence of what I propose is the gendered framework of the shōnen manga genre. The shonen framework restricts the genre's capacity to represent gender performances in two key ways: by inviting the male gaze, and by portraying female characters as 'Good Wife, Wise Mother' (良妻賢母; ryōsai kenbo) archetypes. In doing so, it ensures that shōnen manga appeals to its male readership through narratives rooted in hegemonic masculinity.

John Berger's insights into female representation in visual art underpin my examination of the male gaze in shōnen manga. While the term 'male gaze' was coined by Laura Mulvey in 1975, Berger highlighted the phenomenon in 1972 by showing how some European oil paintings invite viewers to perceive female subjects as primarily sex objects. Operating in this way, a work that adopts the male gaze can be seen as assisting the perpetuation of hegemonic masculinity. Additionally, the preference for the Good Wife, Wise Mother archetype in the shonen framework limits the possible representations of female subjectivity in shonen manga. The Good Wife, Wise Mother is a model of femininity that began as a nineteenth-century education project 
(Inoue 2002) and still persists as an ideal in the minds of many Japanese (Koyama 2013). I argue that these two elements are the central pillars of the shōnen framework, which Akame ga Kill! conforms to and Noragami subverts.

Through my analysis of the male-authored shōnen manga series, Akame ga Kill!, I will show how the shonen framework influences the way male and female characters perform their gender on the page. Against this, I will then show how the female-authored shonen manga series, Noragami, is able to adhere to aspects of the shonen framework while simultaneously challenging them through its characters' gender performances. Noragami is a contemporary example of a female-authored shōnen manga series which is able to further loosen the rigidity of the shonen framework and open the way for greater representation of gender performances in mainstream manga.

\section{Akame ga Kill! and Noragami}

Akame ga Kill! and Noragami have many similarities that make them eligible for comparison. Both titles were serialised in shōnen magazines, followed by tankōbon publications and anime adaptations due to their popularity. ${ }^{4}$ Both titles began serialisation within a year of each other and exist within the same sub-genre of fantasy action/adventure. Due to these similarities a significant crossover of target readerships is likely, making these titles suitable for an analysis of the gendered framework in shōnen manga. A further reason why these series were selected was their characters' gender ratios. Both Akame ga Kill! and Noragami centre on a male character, which is standard for shōnen manga. However, both titles also feature a large cast of female characters, which is atypical for the shonen genre. ${ }^{5}$ As Unser-Schutz (2015) found, it is still common in shōnen manga for male characters to number over $80 \%$ of the total (142), and for male characters take up the majority of the dialogue on the page (141). Because Akame ga Kill! and Noragami each feature a wide range of prominent female characters, they offer an opportunity to analyse the treatment of both male and female characters by authors of both sexes within the shonen manga framework.

\section{Akame ga Kill!}

Akame ga Kill! is a shōnen manga series written by Takahiro (タカヒロ) and illustrated by Tetsuya Tashiro (田代 哲也), who are both male. ${ }^{6}$ It was serialised in Square Enix’s Gangan Joker (ガンガン JOKER) magazine from March 2010 until December 2016, and was adapted into a 24-episode television anime series which aired in 2014. The series title refers to one of the main characters, Akame, describing her as one who "kills". More specifically, the Japanese

\footnotetext{
4 Akame ga Kill! sold 2.1 million tankōbon copies by the release of its tenth volume (“'Akame ga Kiru!' dai-18-wa tōjō" 2014) and Noragami sold 2.2 million tankōbon copies between November 2013 and November 2014 (“TopSelling Manga” 2014).

5 There have been other popular shōnen manga series which centre on a male character and feature a large cast of female characters, including Rumiko Takahashi’s Maison Ikkoku (めぞん一刻; 1980-1987) and Ken Akamatsu’s Love Hina (ラブひな; 1998-2001). However, the plots of these series revolve primarily around romantic and/or sexual encounters between characters.

6 The writer's pen-name is 'Takahiro' only, with no last name.
} 
characters used for “kill” (斬る; kiru) denote the specific meaning of killing a human with a bladed weapon, as Akame does throughout the series.

As the name suggests, Akame ga Kill! is billed as an action manga. Almost every chapter contains bloody and visceral battles between a team of assassins called Night Raid and members of a corrupt government and military. The story begins with Tatsumi, a brown-haired warrior in his mid-teens, who arrives at the capital of a fictional country in search of a job in order to send money back to his poverty-stricken village. On Tatsumi's first day in the capital he meets Leone, a buxom, blonde-haired young woman who swindles him out of all his money. Tatsumi is sleeping on the streets when he is taken in by a wealthy family, but the next evening Night Raid attacks their mansion and kills the family. Tatsumi, who tries to defend the family that sheltered him, becomes engaged in combat with Akame, a sword-wielding, black-haired female fighter around Tatsumi's age. Akame is the superior fighter and is on the verge of killing Tatsumi when Leone emerges and stops her. Leone then reveals why the noble family was targeted by Night Raid: they were known to capture and torture people for their own amusement and would have done the same to Tatsumi had Night Raid not intervened. Leone feels guilty for taking Tatsumi's money, and upon seeing that he is a talented fighter invites him to join Night Raid. The series then follows Tatsumi and the other members of Night Raid as they work to overthrow the corrupt government that has brought poverty and strife to the nation. Akame ga Kill! appeals to its male readership by perpetuating notions of hegemonic masculinity and by sexualising its female characters, and as such follows the general shōnen framework.

\section{Noragami}

Noragami is a shōnen manga series created by Adachitoka (あだちとか), a penname which is a combination of the surnames of Adachi, the character artist, and Tokashiki, the background artist, who are both female. It was serialised in Kodansha's Monthly Shōnen Magazine from December 2010 but has been on hiatus since May 2017 due to the authors' ill health and therefore is presently unfinished ("Noragami Manga" 2017). Noragami was also adapted into two television anime series called Noragami and Noragami Aragoto in 2014 and 2015, respectively. The series title combines the words 'nora' (野良), meaning 'stray' and ' gami' (the suffix form of 'kami'; 神) meaning 'god,' in reference to Yato, the male protagonist of the series. Although Yato is a god, his "stray" label denotes him as a lowly wanderer and also as someone who may change his loyalties at any time.

Noragami tells the fictional story of Yato, one of Japan's lesser-known gods, and a human girl, Hiyori Iki, who is able to leave her body and exist as a spirit. In the tale, Japanese gods are portrayed as answering the prayers of their shrine patrons when given a five-yen tribute. As Yato does not have a shrine of his own, he takes up odd-job requests for a fee of five yen. Calling himself the “Delivery God” (デリバリーゴッド), Yato advertises his services by writing his phone number on public walls. While he is carrying out a job for a client, a chance encounter with Hiyori intertwines their fates and Yato accepts 
Hiyori's request to help prevent her spirit from being able to leave her body. As a shōnen manga series, Noragami conforms to some of the elements in the shonen framework while challenging others through a variety of means, including giving autonomy to female characters and subverting the Good Wife, Wise Mother archetype.

\section{GENDER AND POWER}

Female characters in shōnen manga are often represented as bystanders (Ito 1994) or sexual "commodities" (Jones 2013, 35). This form of representation invites the reader to regard female characters as merely secondary to the male protagonist, or as little more than sexual objects. This approach has been shown to be successful with the genre's target readership: in 1968, Weekly Shōnen Jump "became an instant hit" when it launched with serialisations such as Gō Nagai’s Harenchi Gakuen (ハレンチ学園; 1968-1972), which depicted male characters "catching glimpses of girls' panties or naked bodies" (Ito 2005, 469). This style of sexualisation has been used in shonen manga over the last half-century and has become a consistent part of the shonen framework.

These problems of gender and power are hardly unique to Japan. Commenting on the sexualisation of women through visual representation in European oil paintings, John Berger stated that "men act and women appear. Men look at women" (1972, 47; emphasis original). In describing the phenomenon of women in Western films being depicted as objects of male pleasure, Laura Mulvey noted that "pleasure in looking has been split between active/male and passive/female. The determining male gaze projects its fantasy on to the female figure which is styled accordingly" $(1975,11)$. The "active/male" and "passive/female" elements of the male gaze are very common in shōnen manga. Anne Allison describes the male gaze in shōnen manga as containing three elements: "gender (men look, women are looked at), power (lookers are empowered subjects, the looked at are disempowered objects) and sexuality (looking produces one's own sexual pleasure, being looked at produces another's sexual pleasure)" (Allison 1996, 31). As mainstream shōnen manga series, both Akame ga Kill! and Noragami reproduce the male gaze in some way. This typically involves sexualising female characters outside of the narrative context, a practice often referred to as 'fan service' (Brenner 2007, 88-92). In shōnen manga, 'fan service' typically takes the form of illustrations of female characters that allow the reader to peer up skirts or focus upon breasts, without the characters being privy to the reader's exploitation. Further, it often involves scenes that are irrelevant to the story. For this discussion I will draw on two examples of fan service in Akame ga Kill! in order to demonstrate their invitation of the male gaze within the shōnen framework.

\section{The Male Gaze in Akame ga Kill!}

In Akame ga Kill!, illustrations of female characters wearing revealing clothing, undressing and bathing are all used to appeal to the intended heterosexual male reader. The two examples I will outline in this section involve the male 
protagonist Tatsumi (and the reader) looking at the semi-exposed bodies of female characters. The first example shows the titular female character Akame undressing in front of Tatsumi while seemingly unaware of the sexualisation of her body. In Chapter Three of the series, Tatsumi goes with Akame to gather food for Night Raid, whereupon Akame leads him to a lake to hunt for giant tuna. When arriving at the lake, Akame begins to undress. While this initially startles Tatsumi, he appears dejected when it is revealed that Akame is wearing a bikini under her clothes, implying he had hoped that Akame's motive for undressing was sexual. After Akame removes her outer clothing, the reader is given a close-up shot of her bikini top, followed by a full-body shot (Fig. 1). Akame seems at ease while undressing in front of a boy around her age and seems completely unaware that her actions could be interpreted as sexual. In the frame containing the full-body shot, Akame's words and expressions show no sign of awareness regarding Tatsumi's reaction to her sudden undressing. Akame is framed so that the she is looking directly at the reader, which-when accompanied by a passive expression that is, ironically, not uncommon for her character-shows her as non-threatening and submissive to the male gaze. Further, Akame's body is hyper-sexualised

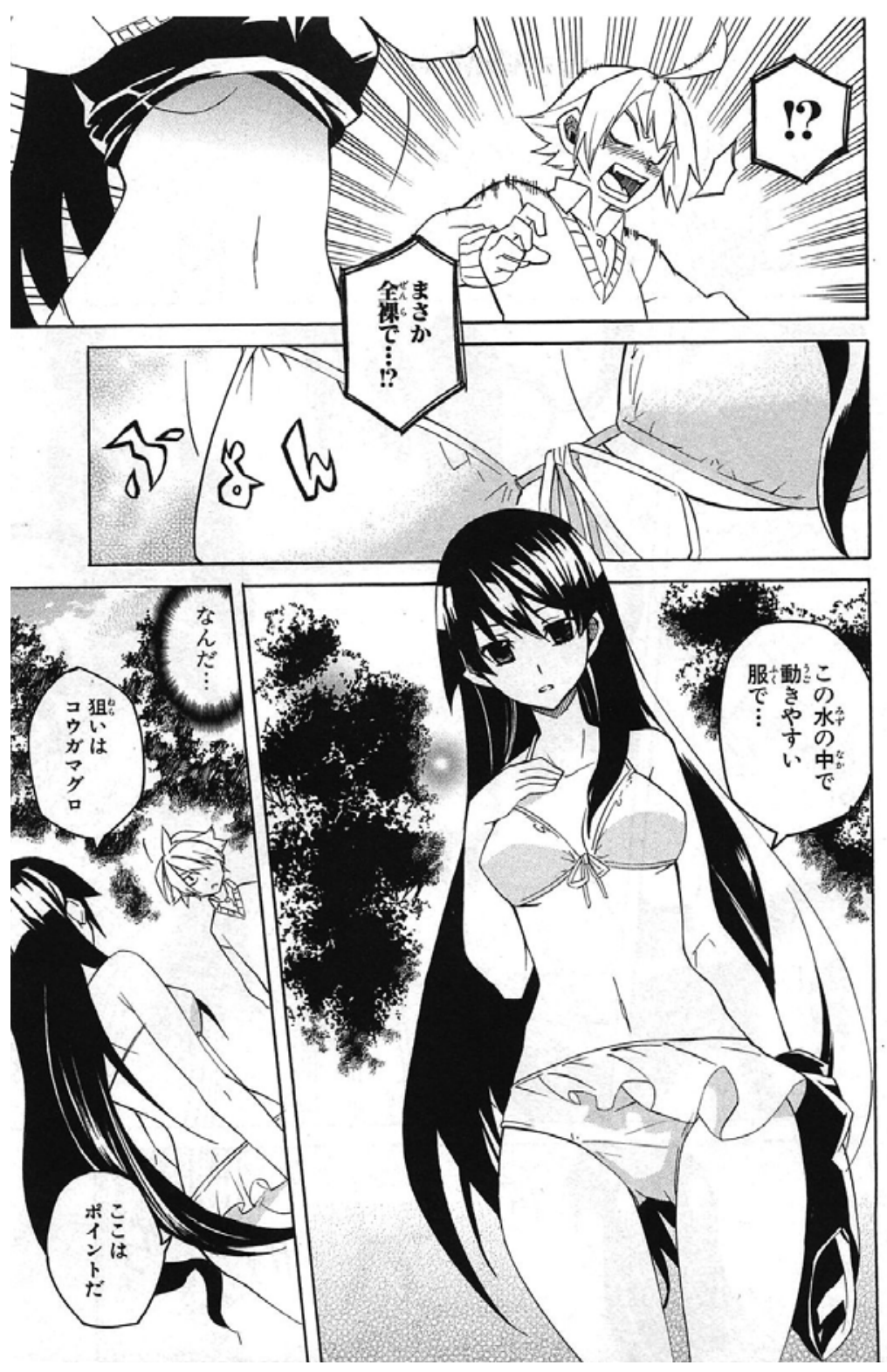

Figure 1: Tatsumi is shocked by Akame's sudden undressing. The reader is shown Akame's body through the male gaze. Source: Akame ga Kiru!, Volume 1, 149. (C) TAKAHIRO, Tetsuya Tashiro/SQUARE ENIX. Reproduced with permission. 
by the onomatopoeic description "fyon" (ふよん) which appears in the frame where her chest is shown, implying that her breasts made a soft, springlike sound when she removed her top. Onomatopoeia is used liberally in manga to describe everyday sounds (Miller 2004, 321); by ascribing sound to Akame's breasts in this way, Akame ga Kill! continues a manga tradition that normalises the sexualisation of women's bodies. This scene speaks directly to the intended heterosexual male readership of shōnen manga by reaffirming Tatsumi's hegemonic masculinity as the source of the male gaze.

In this scene, Akame is shown to exert some agency over her body because she initiated the undressing, but she has no control over its sexualisation in others' eyes. Akame ga Kill! also contains scenes where the sexualised bodies of female characters are revealed to Tatsumi and the reader without the consent of those characters. One example of this is a scene in Chapter Seven, in which Tatsumi inadvertently sees the near-naked bodies of three female comrades without their knowledge. The scene involves a magical item called a teigu (帝具; 'imperial tool'), which Tatsumi tests in Night Raid's hideout. The teigu takes the form of a headpiece with a large eye on the front, which imbues the wearer with certain sight-related abilities. The members of Night Raid are aware of most of the teigu's powers, including granting foresight to the wearer and creating illusions, but are unaware that it also has the power to see through solid objects. When Tatsumi dons the headpiece, it activates and allows him to see through his female comrades' clothes, showing them in their underwear (Fig. 2).

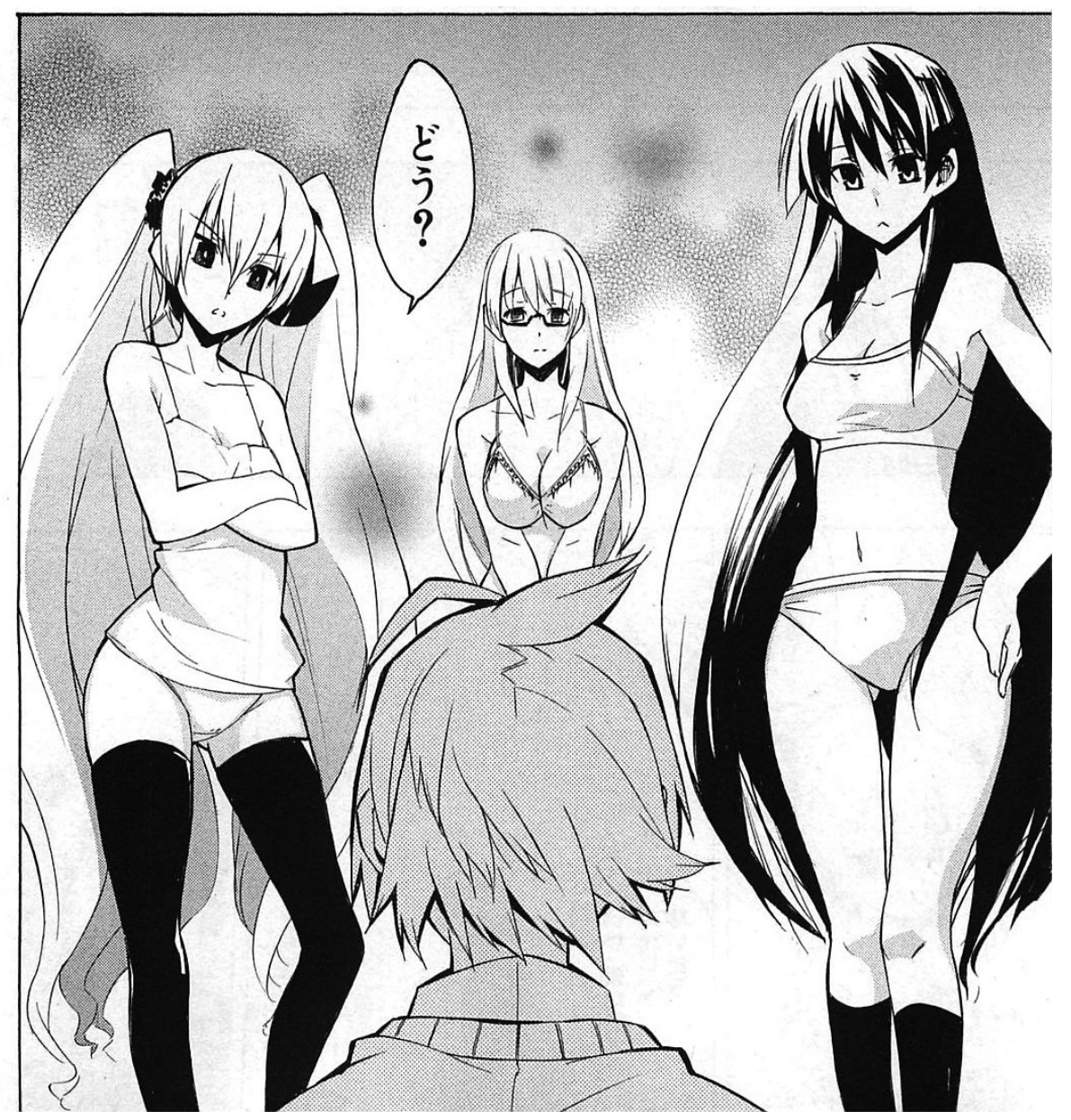

Figure 2: The teigu activates and Tatsumi sees his female comrades in their underwear. Source: Akame ga Kiru!, Volume 2, 102. (C) TAKAHIRO, Tetsuya Tashiro/SQUARE ENIX. Reproduced with permission. 
The three female characters in this scene are given no agency over their bodies as they become subjected to the male gaze. This scene explicitly activates the gendered power dynamic of the male gaze (active/male and passive/female) by showing the female characters as unaware of the way that Tatsumi sees them. The female characters' obliviousness to their exposure is shown by the girl on the left in Figure 2, Main, asking Tatsumi “Well?” (どう?). Then, in Figure 3, the background text to the left of Main's head reads "What's up with him...?" (何コイツ) and Akame, on the right, has a question mark drawn next to her head. However, while the characters themselves are portrayed as oblivious, Main's actions can be read as an indifference to, or even indulgence in the situation. When Main asks Tatsumi "Well?", this acts to both explicitly ask him if the teigu is working and implicitly to ask the reader if they like what they see. After this, Main leans forward when her question is not answered, demanding: "What’s wrong with you?” (どうしたのよ; Fig. 3). The strongly feminine sentence final particle " $n o$ yo" emphasises her femininity and submission to the male gaze (see Hiramoto 2013, 60-61). In leaning forward, she further exposes herself physically, giving Tatsumi and the reader a better angle to peer down her singlet. Main's position in Figure 3 brings to mind the words of John Berger: "It shows her passively looking at the spectator staring at her naked. This nakedness is not, however, an expression of her own feelings; it is a sign of her submission to the owner's feelings or demands" $(1972,52)$. It is in this way that Akame ga Kill! appeals to the power of the male gaze, by giving Tatsumi ownership of the female form.
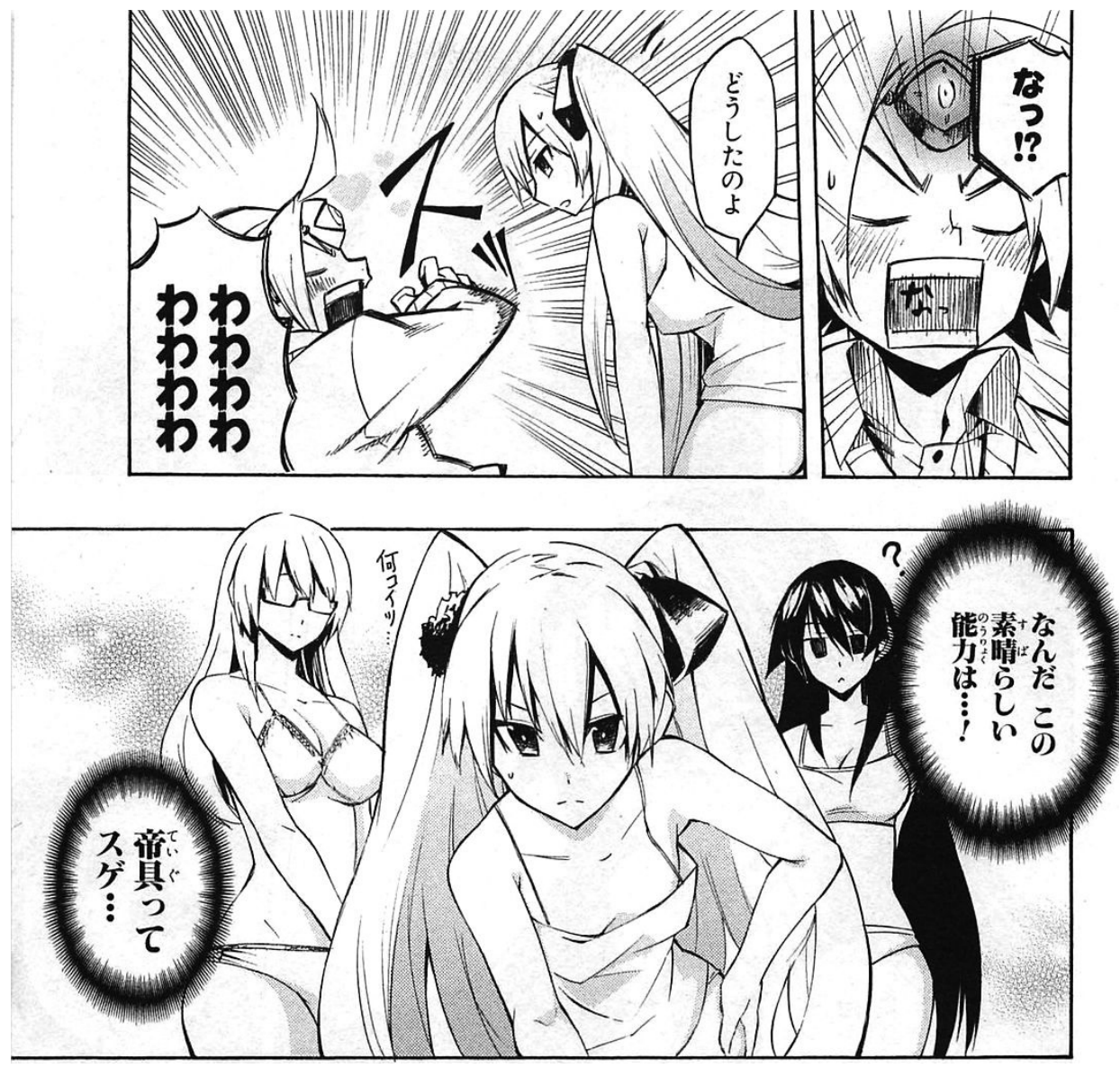

Figure 3: Tatsumi thinks this power is 'wonderful'. The female characters submit to the male gaze. Source: Akame ga Kiru!, Volume 2, 103. (C) TAKAHIRO, Tetsuya Tashiro/ SQUARE ENIX. Reproduced with permission. 
This scene exemplifies the gendered power dynamic in the male gaze as Tatsumi's description of the teigu becomes an analogy for the way shonen manga uses the male gaze without consequence: "What a wonderful ability...! This teigu is amazing...” (なんだこの素晴らしい能力は... 帝具ってスゲ). In much the same way as shonen manga uses the male gaze, the teigu gives Tatsumi (and readers) the power to look upon women's bodies with impunity. Beyond his role as a passive observer, as in the previous scene when Akame undressed, Tatsumi becomes an active and willing consumer of the women's bodies, describing the power to do so as "amazing". While Tatsumi makes no specific mention of his own sexual pleasure, the framing of the final panel places readers in Tatsumi's position, thereby inviting them to join in his voyeurism. The two scenes described above appear in early chapters (Three and Seven, respectively), with many similar scenes present throughout the series' eighty chapters. Akame ga Kill!'s use of the male gaze is an example of how gender representation is commonly framed in the shonen genre. The next section shows how the female-authored Noragami contains fewer instances of the male gaze, and how these are used reflexively to problematise the typical gender dynamics of the shōnen framework.

\section{Female Bodily Autonomy in Noragami}

While Noragami contains far fewer instances of the male gaze than Akame ga Kill!, the central female character is still sexualised. There are intermittent instances throughout the series of the aforementioned 'fan service', which invite the male gaze by allowing the reader to see up Hiyori's skirt or showing her bathing. However, these occurrences are often brief and unfold without the presence of a male character. One notable exception comes in Chapter Twenty-five of Noragami, in which Hiyori's physical body is controlled and exploited by Yato. This scene not only appears noticeably later in Noragami than similar scenes in Akame ga Kill! (showing how much more frequently Akame ga Kill! invites the male gaze), but it also differs greatly in tone. Unlike the previous examples from the male-authored Akame ga Kill!, the femaleauthored Noragami does not show Hiyori (the object of the male gaze) as being oblivious to her sexualisation; rather, it shows her as being fully aware of her objectification and gives her a voice with which to protest against it. In this way, Noragami strikes a skilful balance between fitting the criteria of the shōnen framework, yet simultaneously disrupting the power of this entrenched element of the genre by challenging the idea that female characters are only passive objects for male consumption.

In Chapter Twenty-five, the series takes a break from the primary narrative to present what appears to be an offshoot episode in which Yato uses his power of “divine possession" (神憑) to take control of Hiyori’s body. This involves forcibly removing Hiyori's spirit from her body, thereby allowing Yato to take full control. Yato spends the day in Hiyori's body at her school, promoting his "delivery god" business by flirting with her classmates and teachers and giving up-skirt shots to them. Like the teigu in Akame ga Kill!, Yato's divine possession becomes analogous with the male gaze: it permits Yato full control 
over Hiyori's physical body, which he unhesitatingly sexualises for personal gain. Yato's explanations for taking control of Hiyori's body are varied and inconsistent, and mostly function to add comedy or drama to the scenes. At first, he positions his actions as a comical response to Hiyori's comment that she "wants to be together with Yato more" (もつと夜トと一緒にいたい). However, he later claims that the motive was to advertise his business, and again separately states that he was aiming to win Hiyori's affections.

The divine possession scene begins with Yato seemingly boasting about his power to control Hiyori's body, addressing the readers directly as Hiyori and placing one leg on a table to reveal her underwear (Fig. 4). The real Hiyoriwho is depicted to the left in spirit form-is noticeably embarrassed by this act, as denoted by her blushing face. This scene is followed by a montage of Yato (as Hiyori) interacting with male students and teachers in Hiyori's school, in which he acts out the female role in many stereotypical male fantasies found in shōnen manga (such as asking to be carried somewhere by a male student, sitting on a male teacher's lap, and 'confessing her love' for a group of older male students). In these scenes, the authors appear to demonstrate an awareness of how female characters are subjected to the male gaze in shōnen manga, using parody to "transform existing inequalities and potential threats into pleasure

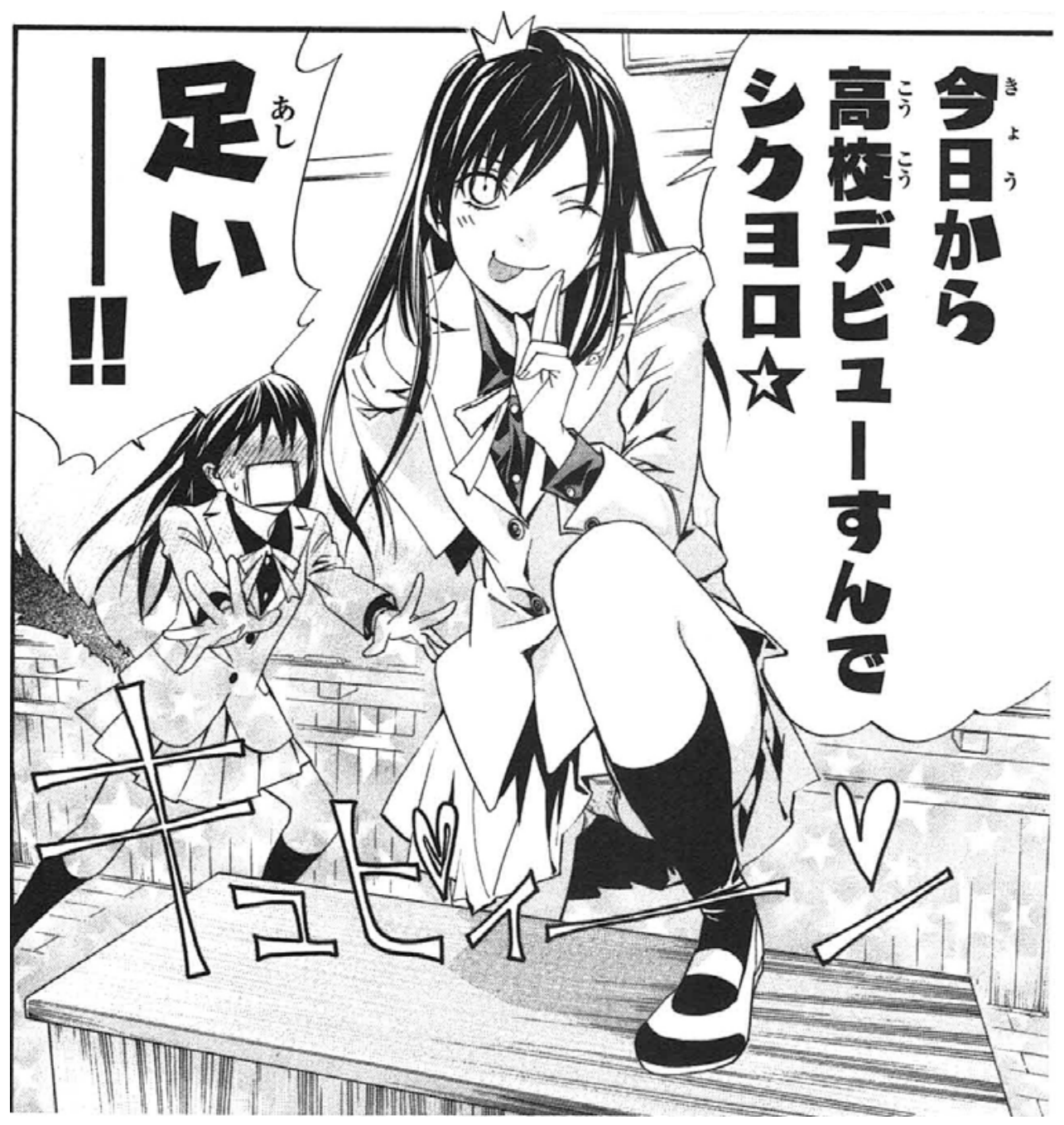

Figure 4: Yato takes control of Hiyori's physical body. Hiyori objects to this while in her spirit form. Yato: “Today is my high school debut, so please treat me well” (今日から高校 デビューすんでシクヨロ). Source: Noragami, Volume 7, 64. ( Adachitoka/Kodansha Ltd., Tokyo. Reproduced in accordance with Section 41 (fair dealing), Australian Copyright Act 1968. 
and gratification [for the reader]" (Aoyama 2012, 66). This gratification comes from the humour derived from a male character (in a female form) behaving in the way women are expected to in shonen manga. During these scenes, Hiyori is denied autonomy as per the shonen framework, but the authors compensate for this by giving her a voice through which she can object to the way her body is being controlled. In every instance in which Yato reveals Hiyori's underwear, either inadvertently or deliberately, Hiyori is there to voice her discomfort. In Figure 4, the spirit Hiyori shouts her objection to how Yato has positioned her leg, letting her classmates and the reader see up her skirt: “[My] leg!!” (足いー!!). In another frame she yells: “Cover it up a little!!!” (ちょっとは隠しなさあーい!!!).

While the divine possession scene grants Hiyori a voice with which to object, shouting her opposition does nothing to stop Yato from controlling her body. Even though she physically fights back against Yato in an attempt to make him surrender her body (Fig. 5), Yato is able to flee from her and causes more mischief. When Yato eventually relinquishes Hiyori's body, it is not because of Hiyori's objections, but because he dislocates her shoulder and cannot endure the pain. Hiyori's objections to how her body is treated gives her no true autonomy in these scenes, and therefore highlights the power imbalance inherent in the male gaze, between those who look and those who are being looked at.

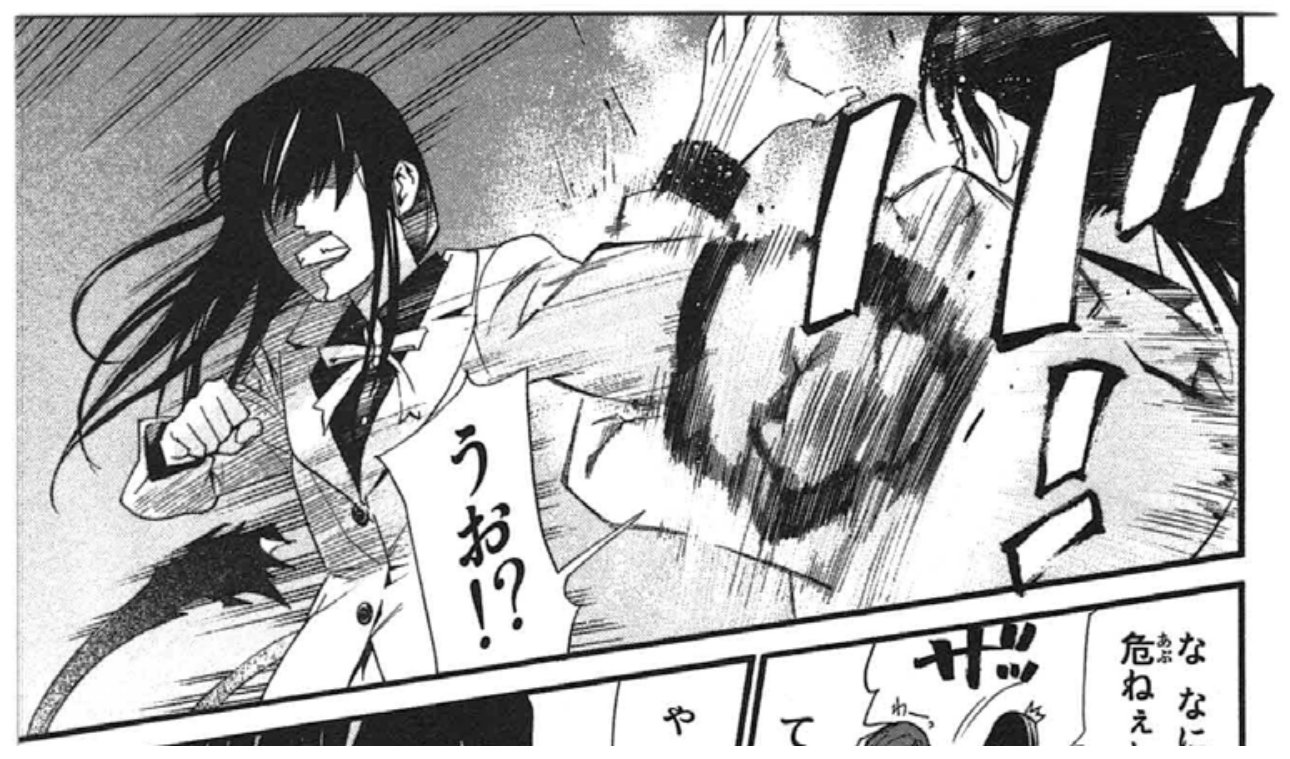

Figure 5: In her spirit form, Hiyori punches her physical body, which is under Yato's control. Source: Noragami, Volume 7, 73. (Adachitoka 2010) (C) Adachitoka/Kodansha Ltd., Tokyo. Reproduced in accordance with Section 41 (fair dealing), Australian Copyright Act 1968.

The divine possession scene represents one of the ways in which Noragami parodies the stereotypical gender roles that are representative of the shonen framework. Through the male gaze, the male becomes an active viewer of the female body, and the female becomes a passive object for his consumption. This is a relationship of power and control whereby the male manipulates the female form in order to fulfil his desires. Akame ga Kill! represents this control through Tatsumi's use of the teigu, and Noragami does so through Yato's power of 'divine possession'. Through these narrative devices, both series draw on 
metaphors of supreme power ('imperial' and 'divine'), positioning the male gaze as a right that comes with the territory of inherited or inherent power and thereby conforming to the shonen framework. However, in Noragami, Hiyori's behaviour in actively trying to end her objectification is contrary to the submission and acceptance shown by the female characters in Akame ga Kill! Within the Noragami narrative, Hiyori acts to reject Yato's control over her body, while on a meta-narrative level, the authors parody the way that the male gaze is typically used to objectify women in shonen manga.

\section{THE GOOD WIFE, WISE MOTHER IN SHŌNEN MANGA}

Unser-Schutz (2015) found that shonen manga uses stereotyped speech more often for female characters than male characters. I argue that beyond just speech, shōnen manga uses stereotyped representations of femininity to inform the way its female characters behave. The primary template that shonen manga uses to represent femininity is the Good Wife, Wise Mother ideal in Japanese society. When choosing to marry and start a family, many Japanese women have traditionally quit their jobs and lost their economic autonomy (Nakamura 2005; Yamamoto and Ran 2014). Their role in Japanese society then becomes one of support for their husband (the 'daikoku-bashira'), and one of primary care-giver for their children. ${ }^{7}$ Even though the term 'Good Wife, Wise Mother' may seem anachronistic in twenty-first-century Japan, the ideal it represents remains the prevailing societal expectation for Japanese women (Koyama 2013, 7) and is still regarded favourably by many Japanese men (Hidaka 2010, 94). As a result, the Good Wife, Wise Mother archetype is present in many examples of shōnen manga and can be identified as part of the shonen framework.

\section{Conforming to the Good Wife, Wise Mother Norm in Akame ga Kill!}

Akame ga Kill! may not immediately seem to be an example of a shōnen manga with submissive or stereotypically feminine characters-after all, most of the female characters found within it are supposedly cold-blooded assassins. However, Katharine Kittredge (2014) points out that manga which portrays physically strong female characters often incorporates elements that mark them as fantasy objects for male readers, counter-balancing this strength with "their heroines' distinct lack of agency" (512). Kittredge observes that this lack of agency is denoted by the female characters' relationships with an adult male character (512). In Akame ga Kill!, this manifests in the way that the female characters 'regress' from unemotional assassins to kind hearted Good Wife, Wise Mother types when they are around male characters. I describe this as a regression not because kind-heartedness should be seen as a lesser trait, but because the nature of Good Wife, Wise Mother is that of a woman in a subservient position to a man. Thus, the female characters regress from active 
to passive subjects when the narrative turns them from active fighters into submissive carers for male characters.

In Akame ga Kill!, the series need not show its female characters as literal wives or mothers to imply that it sees them as Good Wives, Wise Mothers. As the titular character, Akame is a good example of this. She assumes the role of Good Wife, Wise Mother in the way she interacts with Tatsumi, and this role manifests early in their relationship. Akame is shown initially to be cold and emotionless due to her assassin training as a child, and she maintains that persona throughout most of the series. The exceptions to this are when the story inexplicably turns Akame into a Good Wife, Wise Mother by showing her as caring or nurturing towards Tatsumi. This then also serves to reinforce Tatsumi's hegemonic masculinity.

The first scene to reveal this involves Akame and other female members of Night Raid stripping Tatsumi down to his underwear after his first mission. As Tatsumi is shown trying to cover his semi-naked body, it is revealed that by undressing him the others were making sure that Tatsumi was not hiding any wounds beneath his clothing. The members of Night Raid state that it is common for new members to act tough and hide the injuries they receive on their missions. Upon seeing that Tatsumi is unscathed, Akame is seen with a smile on her face for the first time in the series. She then explains that the mortality rate for first missions is high and implies that she was worried about him. This display of care and compassion from Akame is strikingly opposed to her general characterisation as a cold-blooded assassin, but fits with the way that shōnen manga uses female characters as fantasy objects for male readers. Despite years of training to conceal her emotions, Akame's 'femininity' comes out when she is around Tatsumi. Akame may be a sword-wielding coldblooded assassin, but Akame ga Kill! positions her as a subservient Good Wife to Tatsumi; as Kittredge (2014) points out, her "distinct lack of agency" (512) marks her as a fantasy object for male readers.

Some scholars have observed an assumption within Japanese society that many gendered traits have a physiological basis. For instance, anthropologist Akiko Takeyama (2005) found that some Japanese people regard the concept of a 'motherly instinct' as being an inherent part of female biology. This supposedly biological 'motherly instinct' does not necessarily denote a mother-child relationship but is described by some Japanese men as making women "feel good about their devotion to others, in particular the men they love" (Takeyama 2005, 207). This concept of 'motherly instinct' has its roots in the Good Wife, Wise Mother education project of the nineteenth century that "advocated the traditional virtues and values of ideal womanhood, such as obedience to father, husband, and, later, eldest male child" (Inoue 2002, 397). By this metric, a woman's worth is measured by her relationship with men; this devalues her professional identity and places greater emphasis on her role as caregiver to the men in her life. In Akame ga Kill!, the Good Wife, Wise Mother characterisation is not limited to Akame. The series contains a large female cast, and almost all of those who interact with Tatsumi (or another male character) are imbued with similar traits in these interactions. 
One female character who deserves particular attention is one of the series' main antagonists, Esudesu. ${ }^{8}$ In Akame ga Kill!, Esudesu's portrayal implies that despite her status as a professionally accomplished young woman, the absence of a relationship with a man means that she will never be satisfied. Esudesu is a General in the Imperial Army and is widely considered to be the strongest fighter in the Empire. Ironically, she is also shown to be a hopeless romantic. Despite her numerous military achievements, Esudesu feels her existence to be incomplete without a romantic relationship. Upon returning to the capital after securing a significant military victory, Esudesu is tasked with killing the members of Night Raid. The Emperor allows Esudesu to name the reward she would like to receive upon Night Raid's eradication. She responds by saying in humble terms, “I want to try being in love” (恋をしたいと思ってお ります), and requests that the Emperor find her a suitable male partner as her reward. Although such a request could be seen as out of character for someone renowned for their military prowess, the Emperor is unsurprised and implies that he regards it as not unusual for a woman of her age to desire marriage (“将軍も年頃なのに独り身だしな”). This characterisation exemplifies the way that the Good Wife, Wise Mother archetype determines a woman's worth by her relationship with men while dismissing her professional identity. Akame ga Kill! therefore minimises Esudesu's military accomplishments and places greater importance on her relationship status.

Echoing the perception that 'motherly instinct' is an assumed part of female biology, Esudesu explains that her desire for love is a physiological imperative: “This, too, is one of those bestial instincts, huh?” (これも獣の本能 か). Esudesu eventually falls for Tatsumi and her feelings for him then come to consume her identity. She starts keeping a book close to her in which she draws pictures of Tatsumi and writes down advice she receives from others regarding how to make him fall in love with her. Even while carrying out her duties as a general in the Imperial Army, her thoughts inevitably turn to Tatsumi: "Against my better judgement, I look for Tatsumi whenever there are crowds of people” (つい人が多いとタツミを捜して しまう). By this admission, Esudesu explicitly states that her obsession with Tatsumi is something that she feels unable to control, which mirrors the lingering assumption in Japan that a woman's 'motherly instinct' is something unconscious and biological.

Despite Akame being a skilled assassin and Esudesu being an accomplished military general (and an implied sadist, no less), the series imbues each of them with the traits of a Good Wife, Wise Mother-even though that this contradicts their dominant character profiles. Both characters only display their Good Wife, Wise Mother side around or in relation to Tatsumi, which then reinforces Tatsumi's position of power and dominance. Through this, Akame ga Kill! shows the ways in which the shonen framework dictates how gender identities must be characterised in order to reinforce the subordination of women by hegemonic masculinity. In the next section, I will discuss how Noragami imagines alternative roles for women. 


\section{Breaking Free from the Good Wife, Wise Mother in Noragami}

Noragami is able to subvert the shonen framework through its non-stereotypical depictions of several female characters. These characters challenge common shonen tropes and reject traditional gender roles. In the story of Noragami there are two worlds: the higan (彼岸; 'far shore') and shigan (此岸; 'near shore'). ${ }^{9}$ The shigan represents the natural world in which all humans live; however, for Hiyori, it also represents the world in which she feels she is predetermined to become a Good Wife, Wise Mother. Hiyori's story is therefore about breaking free from a world in which she is pressured to conform to the stereotypes of an assigned gender identity. The reader first learns about the pressure Hiyori feels when she is walking home from school while talking with two female friends. Through their conversation, it comes to light that Hiyori is a fan of professional martial arts and that she is choosing to keep this a secret from her parents. The reason for this is because Hiyori thinks her parents will not approve of her 'unfeminine' interest. Hiyori imagines her mother berating her: "Because you're a girl, right!?... You will become a lady who won't bring shame to the Iki family name... And one day you will [get] a fine husband”(あなたは女の子なんですからね!?志岐家の名に恥じぬよう立 派な淑女に...としていずれ立派な婿君を). Through dialogue, the reader learns that Hiyori's interests do not conform to a traditional feminine identity and this is seen as problematic by the people around her. However, in the next frame Hiyori states that she disagrees with her mother, saying she thinks her mother (and her ideas on traditional gender roles) is old-fashioned-a point which is underscored by her mother's language use. ${ }^{10}$ Hiyori desires to live in a world where she is free from rigid gender constructs. This scene sets the stage for how Noragami subverts the shōnen framework by creating a world for Hiyori to experience greater variety of self-expression.

It is soon after this conversation that Hiyori becomes able to transcend her material world and, as a spirit, interact with the gods and phantoms of the higan. Hiyori's encounter with Yato occurs alongside the first instance of her spirit being able to temporarily leave her body, giving her a new perspective on the world and her place in it. Hiyori's spirit form represents her transcendence from the Good Wife, Wise Mother identity imposed on her by her parents and, as an extension of this, by society at large. Hiyori's new situation initially intimidates her as she feels unsure about the path her life will now take: "This is bad! I don’t like this” (困ります!こんなの嫌です). However, she soon comes to appreciate the new-found perspective that her breaks from convention offer: “The scenery I see looks different from usual...This might be fun...” (見 える景色もいつもと違うのです。これはちょっと楽しいかも).

In her spirit form, she enjoys greater freedom and power than she has access to in her earthly form. Hiyori is shown leaving her body during school hours and roaming around town. No longer restricted by physical limitations, Hiyori's spirit form can jump great distances and walk along power lines. With this increase in strength and mobility, Hiyori becomes able to easily replicate techniques performed by the martial artists she often watches. Soon

9 Many concepts from Japanese religion (Buddhism and Shinto) are used to create Noragami's world. The terms 'higan' and 'shigan' are used in Buddhism to refer the world of the living and the spirit realm. 
after meeting Yato, Hiyori (in her spirit form) saves Yato from a phantom by replicating one of these techniques. In contrast to the way Hiyori imagined her mother reacting to her martial arts obsession, Yato is grateful to Hiyori for saving him and, as if to repay her for her kindness, soon agrees to assist Hiyori in preventing her spirit from leaving her body. Significantly, this encounter reverses the gender dynamic of stereotypical 'damsel in distress' rescue scenes, where a helpless female is heroically rescued by a male and subsequently expresses indebtedness to him. These scenes show how Hiyori's journey to the higan grants her the freedom to openly express parts of herself she had previously kept hidden and demonstrates the way in which Noragami is prepared to subvert conventional gender roles.

During her time as a spirit, Hiyori comes to meet other characters who also subvert the Good Wife, Wise Mother archetype. Most notable are two female gods, Bishamonten and Kōfuku, who both also proudly destabilise the Good Wife, Wise Mother model. Bishamonten is a tall, slender woman in her early twenties who often wears semi-revealing clothing. Her appearance defies conventional depictions of the Buddhist deity Bishamonten (毘沙門天), who is usually portrayed as a male warrior dressed in armour (Leeming 2002). Kōfuku, meanwhile, has the appearance of a teenage girl with pink hair. Her language use and behaviour befit her image as a teenage girl: she speaks in mostly gender-neutral 'plain-form' Japanese while occasionally using feminine sentence-final particles. It is later revealed that the character Köfuku is the god of poverty (貧乏神; binboggami), which similarly challenges traditional depictions of this god as a frail old man. In the narrative of Noragami, both Bishamonten and Kōfuku are the heads of their respective households, thereby fulfilling the traditionally male daikoku-bashira role. In contrast, the male character Daikoku, who lives with Kōfuku, is often depicted wearing an apron as a symbol of his domesticity. Daikoku carries out most of the duties around Kōfuku's house: he serves tea when guests arrive and is often seen cooking and cleaning. Daikoku's depiction as a tall and muscular man is incongruous with his role as a traditional housewife, thereby allowing him to act as a parody of that stereotype. These reversals of gender roles in Noragami reject the "conservative, patriarchal view that women's 'proper' place in society is in the home" (Yoda 2006, 267) and open up new ways for gender to be represented within the shonen framework.

Noragami is thus the story of Hiyori exploring alternatives to the Good Wife, Wise Mother identity by experiencing a world of greater possibilities. However, traditional gender roles are shown to be deeply ingrained in Hiyori's character and she risks returning to her old life if she does not actively choose to remain in the higan. After spending some time as a spirit, Hiyori eventually returns to her body and becomes reindoctrinated in the gendered customs of the physical world. During this time, her memories of the higan begin to fade; she behaves more like a stereotypical schoolgirl and feels herself again being pushed into a life not of her choosing. Eventually, however, Hiyori is unwilling to give up her new-found freedom and makes the choice to return to the spirit world where she is not expected to conform to a Good Wife, Wise Mother identity. This outcome may be read in two ways. Firstly, Noragami reads as 
escapist fantasy for Japanese women who feel the need to create a world into which they may escape from their society's patriarchal tendencies. Secondly, Noragami suggests that, for women in Japan, a life free from predetermined gender roles requires one to be an active agent in determining their own gender performance.

The male-authored Akame ga Kill! depicts its female characters as always being subservient to a Good Wife, Wise Mother identity, even if it directly conflicts with their characterisation. The female-authored Noragami, on the other hand, demonstrates an awareness of how female characters are often written through the lens of this gendered ideology, and allows its female characters to break free from it. Through the depictions of Hiyori, Bishamonten and Kōfuku, Noragami offers more varied representations of femininity than the shonen framework appears to allow.

\section{CONCLUSION}

In this paper, I have established the conventional ways in which gender is represented in shonen manga, and have shown how these align with what I call the 'shōnen framework'. The paper began with an examination of how the shonen framework is demonstrated in Akame ga Kill! Through the use of the male gaze and the ryōsai kenbo ideal, the framework restricts the genre's capacity to represent varied gender performances. Despite the dominance of this framework, however, there is potential for its subversion, as shown through my analysis of Noragami. While the focus of this paper has been on using the shonen framework to demonstrate differences between male and female authors' approaches to the genre, applications of the genre framework concept may extend to examinations of shōnen manga series' popularity (within Japan or worldwide), as well as differences in works across generations and genres.

The paper shows how one example of female-authored shōnen manga offers representations of gender performances that depart notably and significantly from the shonen framework. These departures do not always reject the framework altogether, but instead present new ways for gender to be performed within it. Specifically, I have demonstrated how atypical representations of gender performances, such as those in Noragami, are able to loosen the genre's strict gender framework. Insofar as can be ascertained from sales figures, it would seem that Noragami's gender representations have been accepted within shōnen manga's readership, but further research is required to fully understand the effects that female authors have had on the shonen genre and its readers. However, Noragami's broad popularity can be seen as a significant sign that the shonen framework is changing. Female readership of shonen manga has seemingly increased over the last few decades and so it may be interesting to consider how female readers experience these works. This would require further research among female readers of shōnen manga in Japan, which is outside the scope of this paper. Nevertheless, establishing Noragami as an exemplar of the way in which female authors of shonen manga are departing from the genre's gendered framework is an important first step to understanding how these changes will impact readers. 
My comparisons between the male-authored Akame ga Kill! and femaleauthored Noragami demonstrate how female authors have been able to portray representations of gender which are non-conventional to the genre, yet still remain successful in the market. My analysis has focussed on Noragami's subversive portrayal of power in gender relationships and its rejection of traditional gender roles. Through these representations of gender performance, I have argued that Noragami has subverted the shonen framework and created spaces where female characters may be represented in new ways in shōnen manga. As the textual analysis offered in this paper has demonstrated, Noragami has diverged significantly from the simplistic heteronormative gender performances depicted in many shōnen manga works. These, and other departures in other texts, will potentially impact on the ways in which shōnen manga shapes ideas about gender identity in readers.

\section{GLOSSARY}

Bishamonten (毘沙門天)

daikoku-bashira (大国柱)

higan (彼岸)

josei (女性) manga

ryōsai kenbo (良妻賢母)

seinen (青年) manga

shigan (此岸)

shōjo (少女) manga

shōnen (少年) manga

tankōbon (単行本)

teigu (帝具)
A Buddhist deity usually portrayed as a male warrior dressed in armour

the central pillar of a house or building; also a metaphor for the breadwinner of a family

'far shore'; used in Buddhism to refer to the spirit realm

women's manga (lit., females' comics)

'Good Wife, Wise Mother'; a model of femininity that became entrenched in late nineteenth-century Japan

young men's manga

'near shore'; used in Buddhism to refer the realm of the living

girls' manga

boys' manga

'stand-alone book' of manga chapters, as opposed to those serialised in magazines

lit., 'imperial tool'; a made-up word that refers to a magical item in the manga, Akame ga Kill! 


\section{REFERENCES}

“'Akame ga Kiru!' dai 18-wa tōjō no budō daishōgun to rasetsu yonki bijuaru \& seiyū kōkai「アカメが斬る!」第18話登場のブドー大将軍と羅刹四鬼ビジュアル\& 声優公開.” 2014. Livedoor News. Accessed 22 March, 2018. http://news.live door.com/article/detail/9423993/.

Allison, A. 1996. Permitted and Prohibited Desires: Mothers, Comics, and Censorship in Japan. London: Westview Press.

Alverson, B. 2017. "NYCC 2017: Manga Sales Continue to Rise." Publishers Weekly. Accessed 22 March, 2018. https://www.publishersweekly.com/pw/by-topic/ industry-news/comics/article/75066-nycc-2017-manga-sales-continue-torise.html.

Aoyama, T. 2012. "BL (Boys' Love) Literacy: Subversion, Resuscitation, and TransFormation of the (Father's) Text." U.S.-Japan Women's Journal 43: 63-84. https://doi.org/10.1353/jwj.2013.0001/.

Berger, J. 1972. Ways of Seeing. London: Penguin Books.

Brenner, R. 2007. Understanding Manga and Anime. Westport, Connecticut: Libraries Unlimited.

Cattien, J. 2017. "Feminist Epistemology and the Question of Difference Reconfigured: What can Wittgenstein Tell Us about 'Women'?" Journal of International Women's Studies 17 (3): 5-18.

Connell, R. W. 2005. Masculinities. Second Edition. Berkeley and Los Angeles, California: University of California Press.

“Hakkō busū 300-man-bu no 'Shūkan Shōnen Janpu' o sasaeru atsui joshi [発行部 数300万部の「週刊少年ジャンプ」を支える熱い女子].” 2012. Nikkei Style. Accessed 22 March, 2018. https://style.nikkei.com/article/ DGXNASFK31007_R31C12A0000000?channel=DF280120166614/.

Hidaka, T. 2010. Salaryman Masculinity: The Continuity of and Change in the Hegemonic Masculinity in Japan. Boston: Brill. https://doi.org/10.1163/ ej.9789004183032.i-224/.

Hiramoto, M. 2013. "Hey, You're a Girl?: Gendered Expressions in the Popular Anime, Cowboy Bebop.” Multilingua 32 (1): 51-78. https://oi.org/10.1515/ multi-2013-0003/.

Ingulsrud, J. E. and K. Allen. 2010. Reading Japan Cool: Patterns of Manga Literacy and Discourse. Plymouth: Lexington Books.

Inoue, M. 2002. "Gender, Language, and Modernity: Toward an Effective History of Japanese Women's Language.” American Ethnologist 29 (2): 392-422. https://doi.org/10.1525/ae.2002.29.2.392/.

Ito, K. 1994. "Images of Women in Weekly Male Comic Magazines in Japan." Journal of Popular Culture 27 (4): 81-95. https://doi.org/10.1111/j.0022-3840. 1994.2704_81.x/. 
. 2005. "A History of Manga in the Context of Japanese Culture and Society." Journal of Popular Culture 38 (3): 456-75. https://doi.org/10.1111/ j.0022-3840.2005.00123.x/.

Jones, H. 2013. "Manga Girls: Sex, Love, Comedy and Crime in Recent Boys' Anime and Manga." In Manga Girl Seeks Herbivore Boy: Studying Japanese Gender at Cambridge, edited by B. Steger and A. Koch, 23-81. Zurich: LIT Verlag.

Kittredge, K. 2014. "Lethal Girls Drawn for Boys: Girl Assassins in Manga/Anime and Comics/Film." Children's Literature Association Quarterly 39 (4): 50632. https://doi.org/10.1353/chq.2014.0059/.

Koyama, S. 2013. Ryōsai Kenbo: The Educational Ideal of "Good Wife, Wise Mother" in Modern Japan. Translated by S. Filler. Leiden: Brill

Leeming, D. 2002. "Bishamon.” A Dictionary of Asian Mythology. Oxford University Press. Accessed 19 April, 2018. http://www.oxfordreference.com/ view/10.1093/acref/9780195120523.001.0001/acref-9780195120523-e-59/.

Makino, S. and M. Tsutsui. 1995. A Dictionary of Intermediate Japanese Grammar. Tokyo: The Japan Times.

Matanle, P., K. Ishiguro and L. McCann. 2014. "Popular Culture and Workplace Gendering among Varieties of Capitalism: Working Women and Their Representation in Japanese Manga." Gender, Work and Organization 21 (5): 472-89. https://doi.org/10.1111/gwao.12050/.

Miller, L. 2004. "You Are Doing Burikko!” In Japanese Language, Gender, and Ideology: Cultural Models and Real People, edited by S. Okamoto and J. Shibamoto-Smith, 310-45. Oxford: Oxford University Press.

Mulvey, L. 1975. "Visual Pleasure and Narrative Cinema." Screen 16 (3): 6-18. https://doi.org/10.1093/screen/16.3.6/.

Nakamura, A. 2005. "Marital Expectations Help Ensure Singles Ranks Soar." The Japan Times. Accessed 22 March, 2018. https://www.japantimes.co.jp/ news/2005/01/04/national/marital-expectations-help-ensure-singlesranks-soar/\#.WdcPijDaS9I/.

Napier, S. 1998. "Vampires, Psychic Girls, Flying Women and Sailor Scouts." In The Worlds of Japanese Popular Culture: Gender, Shifting Boundaries and Global Cultures, edited by D. P. Martinez, 91-109. Cambridge: Cambridge University Press.

“Noragami Manga Goes on Extended Hiatus Due to Adachitoka's Health." 2017. Anime News Network. Accessed 22 March, 2018. https://www. animenewsnetwork.cc/news/2017-05-01/noragami-manga-goes-onextended-hiatus-due-to-adachitoka-health/.115489/. 
Takeyama, A. 2005. "Commodified Romance in a Tokyo Host Club." In Genders, Transgenders and Sexualities in Japan, edited by M. McLelland and R. Dasgupta, 200-15. New York: Taylor and Francis. https://oi.org/10.4324/ 9780203346839_chapter_14.

“Top-Selling Manga in Japan by Series: 2014.” 2014. Anime News Network. Accessed 22 March, 2018. https://www.animenewsnetwork.com/news/2014-11-30/ top-selling-manga-in-japan-by-series-2014/.81607/.

Ueno, J. 2006. "Shojo and Adult Women: A Linguistic Analysis of Gender Identity in Manga (Japanese Comics).” Women and Language 29 (1): 16-25.

Unser-Schutz, G. 2015. "What Text Can Tell Us About Male and Female Characters in Shōjo- and Shōnen-Manga." East Asian Journal of Popular Culture 1 (1): 133-53. https://doi.org/10.1386/eapc.1.1.133_1/.

Yamamoto, M. and W. Ran. 2014. "Should Men Work Outside and Women Stay Home? Revisiting the Cultivation of Gender-Role Attitudes in Japan." Mass Communication and Society 17 (6): 920-42. https://doi.org/10.1080/1520 5436.2013.860989/.

Yoda, T. 2006. "The Rise and Fall of Maternal Society: Gender, Labor and Capital in Contemporary Japan." In Japan after Japan: Social and Cultural Life from the Recessionary 1990s to the Present, edited by $\mathrm{T}$. Yoda and $\mathrm{H}$. Harootunian, 239-74. Durham and London: Duke University Press. https://doi.org/10.1215/9780822388609-011/.

\section{MANGA REFERENCES}

Adachitoka [あだちとか]. 2010-. Noragami [ノラガミ]. Tokyo: Kōdansha [講談社].

Takahiro [タカヒロ] and T. Tashiro [田代 哲也]. 2010-2016. Akame ga Kiru! [アカメが 斬る! ]. Tokyo: Square Enix [スクウェア・エニックス]. 